Invited review

\title{
Astrochronostratigraphic polarity time scale (APTS) for the Late Triassic and Early Jurassic from continental sediments and correlation with standard marine stages
}

\author{
Dennis V. Kent ${ }^{\mathrm{a}, \mathrm{b}, *}$, Paul E. Olsen ${ }^{\mathrm{b}}$, Giovanni Muttoni ${ }^{\mathrm{c}}$ \\ a Earth and Planetary Sciences, Rutgers University, Piscataway, NJ 08854, USA \\ b Lamont-Doherty Earth Observatory of Columbia University, Palisades, NY 10964, USA \\ ' Dipartimento di Scienze della Terra 'Ardito Desio', Università degli Studi di Milano, via Mangiagalli 34, I-20133 Milan, Italy
}

\section{A R T I C L E I N F O}

\section{Article history:}

Received 22 July 2016

Received in revised form 23 December 2016

Accepted 23 December 2016

Available online 05 January 2017

\begin{abstract}
A B S T R A C T
Paleomagnetic and cycle stratigraphic analyses of nearly $7000 \mathrm{~m}$ of section from continuous cores in the Newark basin and an overlapping 2500 meter-thick composite outcrop and core section in the nearby Hartford basin provide an astrochronostratigraphic polarity time-scale (APTS) for practically the entire Late Triassic (Carnian, Norian and Rhaetian) and the Hettangian and early Sinemurian stages of the Early Jurassic (233 to $199 \mathrm{Ma}$ in toto). Aperiodic magnetic polarity reversals make a distinctive pattern of normal and reverse chrons for correlation, ideally paced by the periodic timing of orbital climate cycles, and anchored to million years ago (Ma) by high-precision U-Pb zircon dates from stratigraphically-constrained basalts of the Central Atlantic Magmatic Province (CAMP). Pinned by the CAMP dates, the Newark-Hartford APTS is calibrated by sixty-six McLaughlin cycles, each a reflection of climate forcing by the long astronomical eccentricity variation with the stable $405 \mathrm{kyr}$ period, from 199.5 to $225.8 \mathrm{Ma}$ and encompassing fifty-one magnetic polarity intervals, making it one of the longest continuous astrochronostratigraphic polarity time-scales available in the Mesozoic and Cenozoic. Extrapolation of sediment accumulation rates in fluvial sediments in the basal Newark section extends the sequence an additional fifteen polarity intervals to $232.7 \mathrm{Ma}$. The lengths of the 66 polarity chrons vary from $0.011 \mathrm{Myr}$ (Chron E23r) to $1.63 \mathrm{Myr}$ (Chron H24n) with an overall mean duration of $0.53 \mathrm{Myr}$. The oldest CAMP basalts provide a zircon U-Pb-based estimated age of $201.5 \mathrm{Ma}$ for the base of the stratigraphically superjacent McLaughlin cycle 61 and 201.6 Ma using cycle stratigraphy for the onset of the immediately subjacent Chron E23r. The calibration age of 201.5 Ma for the base of McLaughlin cycle 61 is remarkably consistent with the calculated phase of the 498th long eccentricity cycle counting back using a period of $405 \mathrm{kyr}$ from the most recent peak at $0.216 \mathrm{Ma}$. Accordingly, we suggest a nomenclature (Ecc405:k, where $\mathrm{k}$ is the cycle number or fraction thereof) to unambiguously assign ages from the astrochronostratigraphy. Magnetostratigraphic correlation of key Tethyan sections with diagnostic marine biostratigraphic elements to the Newark-Hartford APTS allows determination of numerical ages of standard marine stages, as follows: $227 \mathrm{Ma}$ for the Carnian/Norian boundary, 205.5 Ma for the Norian/ Rhaetian boundary (using a chemostratigraphic criterion, or about 4 Myr older for alternative criteria), 201.4 Ma for the Triassic/Jurassic boundary, and 199.5 Ma for the Hettangian/Sinemurian boundary. These age estimates are in excellent agreement with available constraints from high-precision U-Pb zircon dating from the Pucara Basin of Peru and along with the presence of the short Chron E23r in several basins argue strongly against suggestions that millions of years of Rhaetian time is missing in a cryptic hiatus or unconformity that supposedly occurs just above Chron E23r in the Newark Supergroup basins. It is more parsimonious to explain the apparent temporal delays in appearances and disappearances of palynoflora, conchostracans, and other endemic taxa in continental deposits as a reflection of demonstrated continental drift across climate belts and the misinterpretation of ecostratigraphy as chronostratigraphy. The Newark-Hartford APTS provides a chronostratigraphic template for continuing efforts at correlation of Late Triassic and Early Jurassic continental and marine sections throughout the world, including integration with atmospheric $p \mathrm{CO}_{2}$ measurements from paleosol carbonates and carbon isotopic measurements from marine carbonates to better understand the global carbon cycle as well as understanding the causes of and recovery from the end-Triassic mass extinction.
\end{abstract}

(c) 2017 Elsevier B.V. All rights reserved.

\footnotetext{
* Corresponding author at: Earth and Planetary Sciences, Rutgers University, Piscataway, NJ 08854, USA.

E-mail address: dvk@rutgers.edu (D.V. Kent).
} 


\section{Contents}

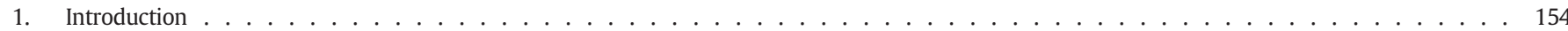

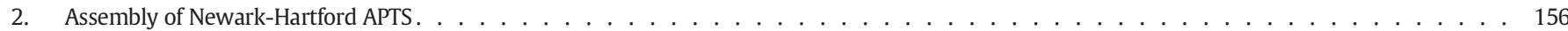

2.1. Newark and Hartford magnetozone sequence . . . . . . . . . . . . . . . . . . . . . . . . . . . . . 156

2.2. Newark and Hartford orbital climate cycles . . . . . . . . . . . . . . . . . . . . . . . . . . . . 157

2.3. Astrochronological age model anchored by U-Pb dates . . . . . . . . . . . . . . . . . . . . . . . . . . . . . . . . . . . . 159

2.4. Comparison of Newark-Hartford APTS with previous time-scales ～. . . . . . . . . . . . . . . . . . . . . 163

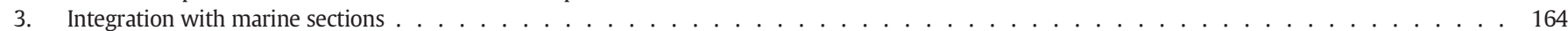

4. Comparison of Newark-Hartford APTS with other U-Pb dates . . . . . . . . . . . . . . . . . . . . . . . . . . . . . . . . . . . . . . 167

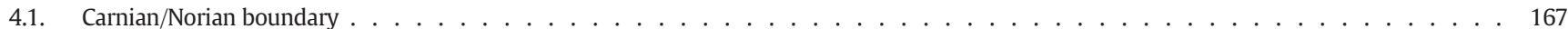

4.2. Norian/Rhaetian boundary. . . . . . . . . . . . . . . . . . . . . . . . . . . . . 169

4.3. Triassic/Jurassic and Hettangian/Sinemurian boundaries . . . . . . . . . . . . . . . . . . . . . . . . . . . . . . . 169

5. Extension of the Newark-Hartford APTS into younger and older strata . . . . . . . . . . . . . . . . . . . . . . . . . . . . . . . . . 169

5.1. Sinemurian and younger . . . . . . . . . . . . . . . . . . . . . . . . . . . 169

5.2. Carnian and older. . . . . . . . . . . . . . . . . . . . . . . . . . . . . . . . . . . . . . . 169

6. The 'missing' Rhaetian . . . . . . . . . . . . . . . . . . . . . . . . . . . . . . . . . . . . . . . . . . . . . 171

7. $\mathrm{pCO}_{2}$ estimates from paleosols and the $\delta^{13} \mathrm{C}$ record from marine carbonates. . . . . . . . . . . . . . . . . . . . . . . . . . . . . . . 172

8. Correlations of continental sediments and paleogeography . . . . . . . . . . . . . . . . . . . . . . . . 174

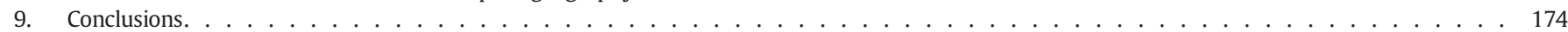

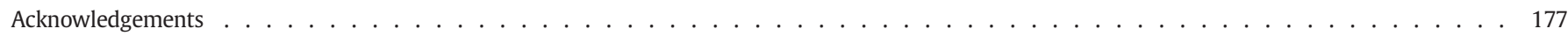

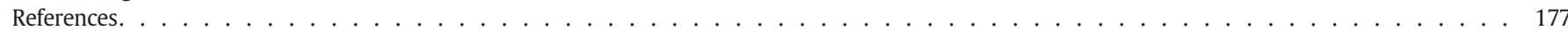

\section{Introduction}

Recently compiled geological time-scales (GTS) have had particular difficulty with Triassic chronology. This is especially evident from the wide disparity in age estimates for the Carnian/Norian boundary, which changed from 216.5 Ma (Mega-annum or million years ago) in GTS2004 (Gradstein et al., 2004) to 228 Ma in GTS2012 (Gradstein et al., 2012). The difference of $>10 \mathrm{Myr}$ (million years in duration) made it one of the largest boundary age revisions in the Phanerozic in these time-scales. The change was largely due to avoidance in GTS2004 of U-Pb dates from the Latemar series of Ladinian age (which, ironically, had perhaps more U-Pb dated levels than any stage in the Triassic) that disagreed with the then-prevalent perception of a low sedimentation rate (50 m/Myr) and long duration (about $12 \mathrm{Myr}$ ) for the Latemar. This compared to better-substantiated values a full order of magnitude higher and shorter (500 m/Myr and only $1 \mathrm{Myr}$; see decisive numerical analysis by Meyers (2008)) and had the effect of squeezing or shortening other stages in the Triassic, like the Carnian. An updated chronology as summarized in Fig. 1 and described in detail below now makes the Late Triassic (Carnian, Norian, Rhaetian stages), at $>35 \mathrm{Myr}$ in duration, one of the longest epochs in the Phanerozoic.

Despite its considerable duration, there are few direct age calibrations for Late Triassic marine sections with biostratigraphy, which are traditionally used to define standard geological stages, and the available dates provide a geochronological resolution of only 5-10 Myr at best. The widely studied fossiliferous albeit condensed Hallstatt marine facies offer a better biochronological resolution of around $3 \mathrm{Myr}$ ( 4 biozones with about 11 subzones) but the common presence of unconformities (mostly hardground hiatuses) limits the use of sediment thickness as a first-order proxy of time for interpolation and development of a reliable composite sequence (e.g., Krystyn et al., 2002). A continental timescale based on tetrapod biochronology has even lower resolution of about 8 Myr with only two to four land vertebrate faunachrons recognized in the entire Late Triassic (Lucas, 2010). Direct Triassic marineterrestrial links are even more limited in number, essentially confined to the mass extinction in both marine and nonmarine biota just prior to the Triassic-Jurassic boundary (TJB) (Benton et al., 2014). In continental rift basins of the now-dispersed Pangea supercontinent, the TJB has been inferred to be in close temporal proximity to the older lavas of the Central Atlantic Magmatic Province (CAMP), which also provide key high-precision U-Pb dates for time-scale calibration (Blackburn et al., 2013). The precise timing of global events leading up to the end-
Triassic extinctions and biotic recovery into the Early Jurassic is of interest to constrain the possible cause(s) of the extinction event, its development in different fossil groups and environments, and the pace and nature of the biotic recovery. More broadly, an accurate depiction of the timing of processes reflected in the rock record is invaluable to gauge the intermingled roles of paleogeography and greenhouse gases on global climate (Goddéris et al., 2008; Schaller et al., 2015) and the distribution of biota (e.g., Kent et al., 2014; Whiteside et al., 2011a, 2011b).

Our strategy for developing a temporal template for global correlation in the Late Triassic and earliest Jurassic was to rely on the thickest and longest sedimentary sections available from both continental and marine environments that contain one or more chronostratigraphic proxies for dating and correlation. The initial framework was established from continuous scientific and geotechnical coring of $\sim 5000$ m-thick terrestrial deposits in the Newark basin under the Newark Basin Coring Project (NBCP) and Army Corps of Engineers (ACE) cores (Olsen et al., 1996a) (Fig. 1). These and related strata of the Newark Supergroup in the rift basins of Eastern North America range in age from the Carnian to the Hettangian and Sinemurian based on palynofloral zones and land vertebrate faunachrons (Cornet and Traverse, 1975; Huber et al., 1993; Olsen and Cornet, 1988; Olsen et al., 2011; Weems and Olsen, 1997). Most significantly, the lacustrine facies that can be found in all but the lower portion of the thick Newark basin sedimentary section pervasively reflects the imprint of Milankovitch climate cyclicity and this orbital signal provides a means of pacing the deposition on a much finer 10-100 kyr scale (Olsen, 1986).

The Newark and related rift basin rocks were initially regarded as recording only normal polarity (the Newark Normal Interval of Perchersky and Khramov (1973) and Graham Normal Interval of McElhinny and Burek (1971)). However, it eventually became clear that this applied only to the disproportionately studied Newark Supergroup igneous rocks whereas the much thicker sedimentary units of much longer duration beneath the lavas were soon observed to have numerous normal and reverse polarity magnetozones; the stratigraphic distribution of the magnetozones was initially assembled from basinwide sampling of outcrops and short cores (McIntosh et al., 1985; Witte and Kent, 1989; Witte et al., 1991) and culminated with the detailed paleomagnetic and chronostratigraphic record from the NBCP cores (Kent et al., 1995; Olsen and Kent, 1996). After some refinements in the polarity sequence, the resulting astrochronostratigraphic polarity time-scale (APTS) (Kent and Olsen (1999); see Olsen et al. (2011) for 

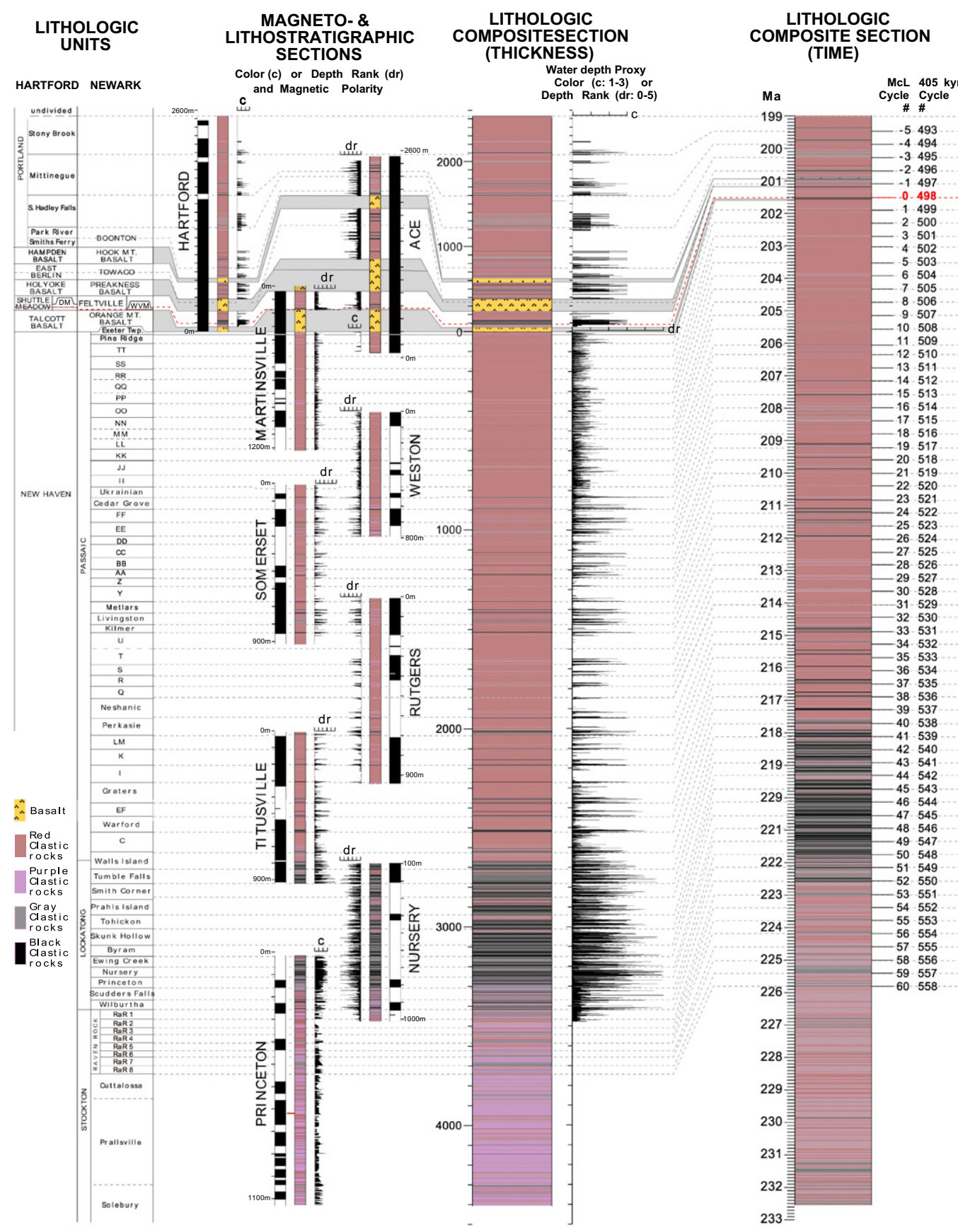
POLARITY
POMPOSITE

$\begin{array}{ll}\text { (TIME) } & \text { AGES \& EPOCHS } \\ & \end{array}$ STRATIGRAP Water depth Proxy
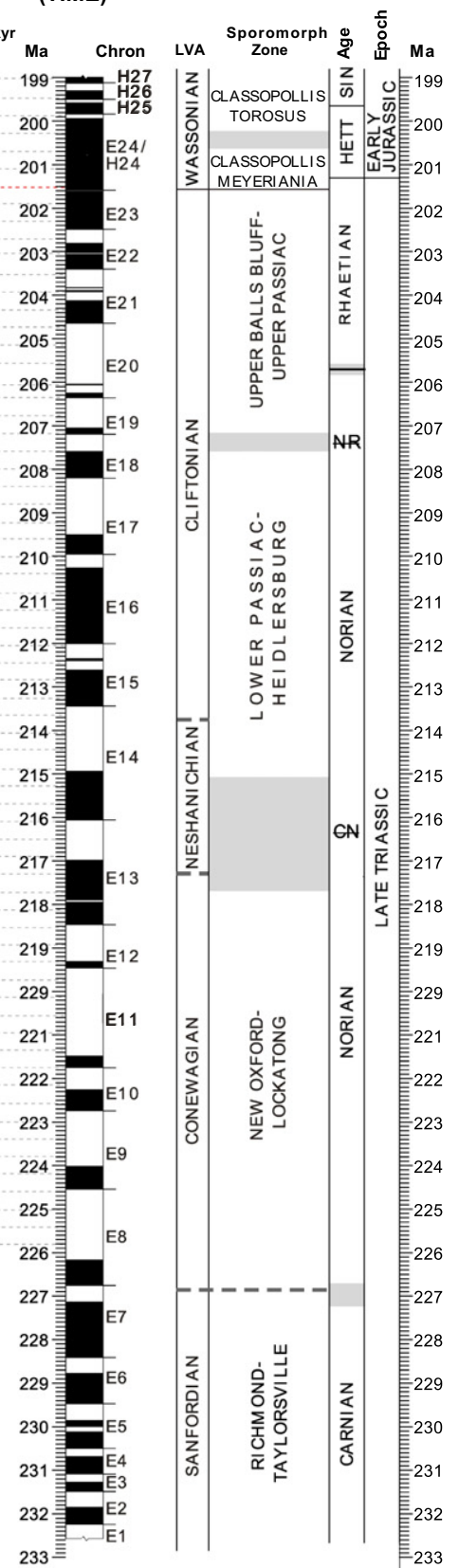

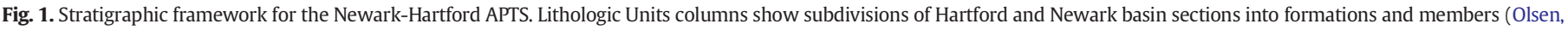

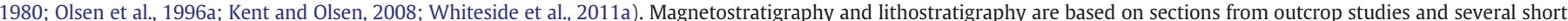

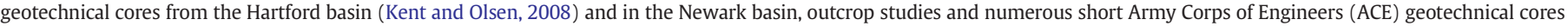

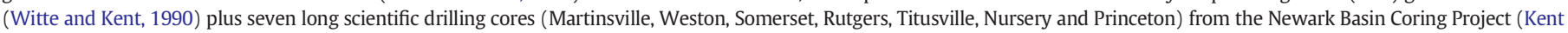

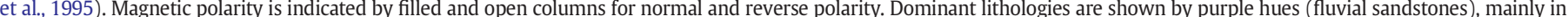

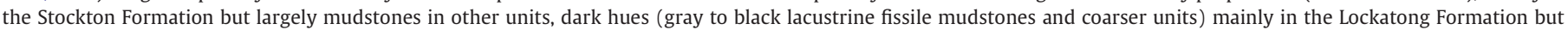

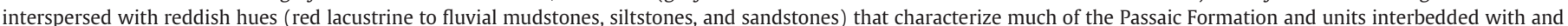

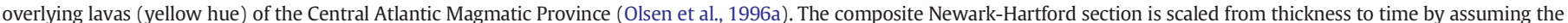

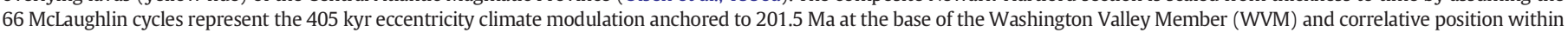

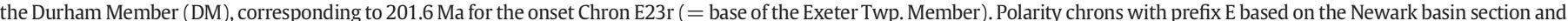

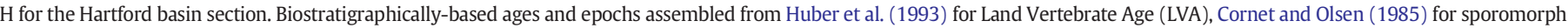

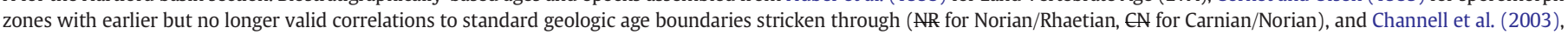

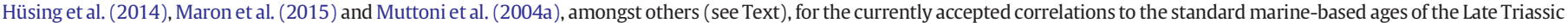
and Early Jurassic.

summary of various Newark APTS variants) was anchored to available $\mathrm{U}-\mathrm{Pb}$ dates (rounded to $202 \mathrm{Ma}$ ) from the Palisade Sill tied to the oldest basalt lava sequence (Orange Mountain Basalt). This flood basalt event, now recognized as part of CAMP (Marzoli et al., 1999), was determined to have been short-lived (only about $600 \mathrm{kyr}$ ) based on Milankovitch cyclicity in the sedimentary strata interbedded with the lavas (Olsen et al., 1996b). The polarity and climate cycle sequences were subsequently extended upward by several million years into the Early Jurassic 
in the $>2000 \mathrm{~m}$ of outcrop strata above the CAMP basalts in the Hartford basin (Kent and Olsen, 2008), which together with the data from the Newark basin, provide the working framework for the Late TriassicEarly Jurassic Newark-Hartford APTS.

With the general lack of radiometrically dated horizons or clear Milankovitch signatures in most Late Triassic marine sections, magnetostratigraphy has become a powerful tool for correlation to the Newark-Hartford APTS to develop an integrated global chronology. Workers eventually sought the thickest and longest marine sections (although not necessarily the most fossiliferous) to minimize the distorting effects of discontinuities in deposition on the magnetic polarity pattern. Some of the key reference sections with magnetobiostratigraphy for this time frame are Silicka Brezova in Slovakia (Channell et al., 2003) and Pizzo Mondello in Sicily (Muttoni et al., 2004a) for the Carnian and Norian, Brumano-Italcementi in the Southern Alps (Muttoni et al., 2010) and Pignola-Abriola in Southern Italy (Maron et al., 2015) for the Norian and Rhaetian, and St. Audrie's Bay and East Quantoxhead in Britain for the Rhaetian to Sinemurian, most of which now also has an astronomically-calibrated magnetobiostratigraphy (Hounslow et al., 2004; Hüsing et al., 2014; Ruhl et al., 2010). Available U-Pb zircon dates on ash layers in marine sections, notably from Peru (Guex et al., 2012; Schaltegger et al., 2008; Schoene et al., 2010; Wotzlaw et al., 2014) and Italy (Furin et al., 2006; Mietto et al., 2012), lack magnetostratigraphic control and depend on biostratigraphic correlation or the dates themselves for integration with the APTS. Hounslow and Muttoni (2010) provide an extensive catalog and discussion of magnetobiostratigraphic sections for the entire Triassic, with an emphasis on marine stage boundary definitions and correlations.

The plan of the paper is to 1) outline the development of the APTS framework from the polarity sequence and cycle stratigraphy of the Newark and Hartford basins, 2) anchor the APTS at the base of Chron E23r and the Exeter Township (Twp.) Member to the best-fit $405 \mathrm{kyr}$ eccentricity cycle counting from the present using published high-precision U-Pb zircon dates on the earliest CAMP volcanics and available astronomical solutions, 3) review correlations of the magnetostratigraphy of key marine sections and standard marine stages to the APTS, and 4) compare and test the APTS with independent U-Pb dates from outside the Newark and Harford basins. We conclude by offering motivations and suggestions for further work and prognoses of their likely success.

\section{Assembly of Newark-Hartford APTS}

\subsection{Newark and Hartford magnetozone sequence}

For the Late Triassic, the framework for the paleomagnetic polarity sequence is constructed from data from seven partially overlapping NBCP drill cores totaling $>6700 \mathrm{~m}$ in length with better than $99 \%$ core recovery (Table 1 ). The cored sections were compiled into an approximately 5000 m-thick composite section with about $25 \%$ redundancy in stratigraphic coverage (Olsen et al., 1996a). The initial sampling interval of nominally $2.75 \mathrm{~m}$ (one sample plug of the most favorable lithology per $\left(9^{\prime}\right)$ core box) yielded 2400 samples. Early acquired characteristic

Table 1

Corrected locations ${ }^{\mathrm{a}}$ for NBCP core sites.

\begin{tabular}{llllll}
\hline \multirow{2}{*}{ Name } & \multicolumn{2}{l}{ Decimal degrees } & & \multicolumn{2}{l}{ Degrees Minutes Seconds } \\
\cline { 2 - 3 } \cline { 5 - 6 } \cline { 5 - 6 } & Latitude & Longitude & & Latitude & Longitude \\
North & West & & North & & West \\
\hline Martinsville & $40.611446^{\circ}$ & $74.574368^{\circ}$ & & $40^{\circ} 36^{\prime} 41.21^{\prime \prime}$ & $74^{\circ} 34^{\prime} 27.72^{\prime \prime}$ \\
Weston & $40.542116^{\circ}$ & $74.562873^{\circ}$ & & $40^{\circ} 32^{\prime} 31.62^{\prime \prime}$ & $74^{\circ} 33^{\prime} 46.34^{\prime \prime}$ \\
Somerset & $40.505764^{\circ}$ & $74.565386^{\circ}$ & & $40^{\circ} 30^{\prime} 20.75^{\prime \prime}$ & $74^{\circ} 33^{\prime} 55.39^{\prime \prime}$ \\
Rutgers & $40.526411^{\circ}$ & $74.433083^{\circ}$ & & $40^{\circ} 31^{\prime} 35.08^{\prime \prime}$ & $74^{\circ} 25^{\prime} 59.10^{\prime \prime}$ \\
Titusville & $40.318858^{\circ}$ & $74.849922^{\circ}$ & & $40^{\circ} 19^{\prime} 07.89^{\prime \prime}$ & $74^{\circ} 50^{\prime} 59.72^{\prime \prime}$ \\
Nursery & $40.289598^{\circ}$ & $74.823748^{\circ}$ & & $40^{\circ} 17^{\prime} 22.55^{\prime \prime}$ & $74^{\circ} 49^{\prime} 25.49^{\prime \prime}$ \\
Princeton & $40.361275^{\circ}$ & $74.613286^{\circ}$ & & $40^{\circ} 21^{\prime} 40.59^{\prime \prime}$ & $74^{\circ} 36^{\prime} 47.83^{\prime \prime}$ \\
\hline
\end{tabular}

a GoogleEarth Coordinates (Map Datum WGS84). magnetizations could be isolated from hematite-bearing as well as magnetite-bearing sediment facies. Principal component analysis of progressive thermal demagnetization data allowed the delineation of 59 polarity intervals ranging from $4 \mathrm{~m}$ to over $300 \mathrm{~m}$ in stratigraphic thickness (Kent et al., 1995) (Fig. 1). Of great importance are the tests of lateral continuity and consistent relationship of the magnetozones to lake level cycles in the stratigraphically overlapping sections of the drill cores. In all six comparisons between the overlapped portions of the seven NBCP cores, some up to $42 \mathrm{~km}$ apart (Fig. 2), there was no violation between the lithologic marker beds (i.e., cyclostratigraphy) and polarity magnetozones, demonstrating their mutual validity as time horizons. Every overlap zone has at least one polarity transition and the polarity is consistent even when lateral facies changes include a change of color and magnetic mineralogy. This dataset was supplemented by higher density sampling (every $0.3 \mathrm{~m}$ or so) across 42 magnetozone boundaries representing 35 different polarity reversals in the lacustrine Lockatong and Passaic Formations (although no additional sampling was done in the fluvial Stockton Formation) (Kent and Olsen, 1999). Each pairwise correlation of the overlap zones of the core demonstrates the reproducibility of both the magnetostratigraphy and cyclostratigraphy over much of the central Newark basin.

The reverse polarity magnetozone at the base of the recovered section (Stockton Formation in the Princeton NBCP core) is designated E1r and succeeding pairs of predominantly normal and predominantly reverse polarity intervals are numbered upward as E2n, E2r; E3n, E3r; etc., with the suffix for the dominant polarity ( $n$ is normal polarity, $r$ is reverse) of each constituent submagnetozone. To balance the stratigraphic thickness of first rank magnetozones over the entire section and to avoid having short polarity intervals at their boundaries, selected shorter polarity intervals were assigned subordinal integers (ascending upsection) that are appended after a decimal point to the higher-order magnetozone designation and also given a suffix indicating dominant polarity, for example, E22n is comprised of E22n.1n, E22n.1r, and E22n.2n. The overall nomenclature scheme is similar to that for the Late Jurassic to Cenozoic polarity sequence derived from marine magnetic anomalies (e.g., Cande and Kent, 1992; Channell et al., 1995; Harland et al., 1982) except those were numbered from youngest to oldest whereas the polarity magnetozones and corresponding chrons for the Hartford-Newark APTS are numbered from oldest to youngest in deference to standard stratigraphic practice.

In the Newark basin, the uppermost 1000 m-thick section of interbedded volcanics and continental sediments of mostly Early Jurassic age is characterized by normal polarity. This was known from early paleomagnetic studies (Opdyke, 1961) and subsequently confirmed by data from outcrop and short geotechnical cores (McIntosh et al., 1985; Witte and Kent, 1990) as well as the stratigraphically highest (Martinsville) NBCP core (Kent et al., 1995). This thick normal polarity magnetozone was elevated in rank to E24n from its previous designation E23n.2n (Kent et al., 1995) on the strength of data supporting the existence of the preceding short reverse polarity interval that became E23r (from E23n.lr) (Kent and Olsen, 1999). In the nearby Hartford basin, paleomagnetic study of samples from 80 sites and 15 geotechnical cores distributed over a $2500 \mathrm{~m}$-thick section of sedimentary units that are interbedded with and overlie the same sequence of lavas as in the Newark basin extends the polarity record another 2 Myr according to cycle stratigraphic analysis (Kent and Olsen, 2008) (Fig. 3). A magnetostratigraphy was not developed in the fluviatile New Haven Arkose that underlies the lavas in the Harford basin because of a lack of marker beds to tie together the discontinuous outcrops. Nevertheless, the correlative Chron E24n in the Harford basin was designated H24n for convenience and the succeeding polarity magnetozones are labeled $\mathrm{H} 24 \mathrm{r}$ through $\mathrm{H} 27 \mathrm{n}$ (partim).

There are a total of 66 magnetozones in the Newark and Hartford basin sections with the lowermost (E1r) and uppermost (H27n) polarity zones are perforce unbounded stratigraphically. The thickest magnetozone at just over $1500 \mathrm{~m}$ is E24n/H24n, which includes all 


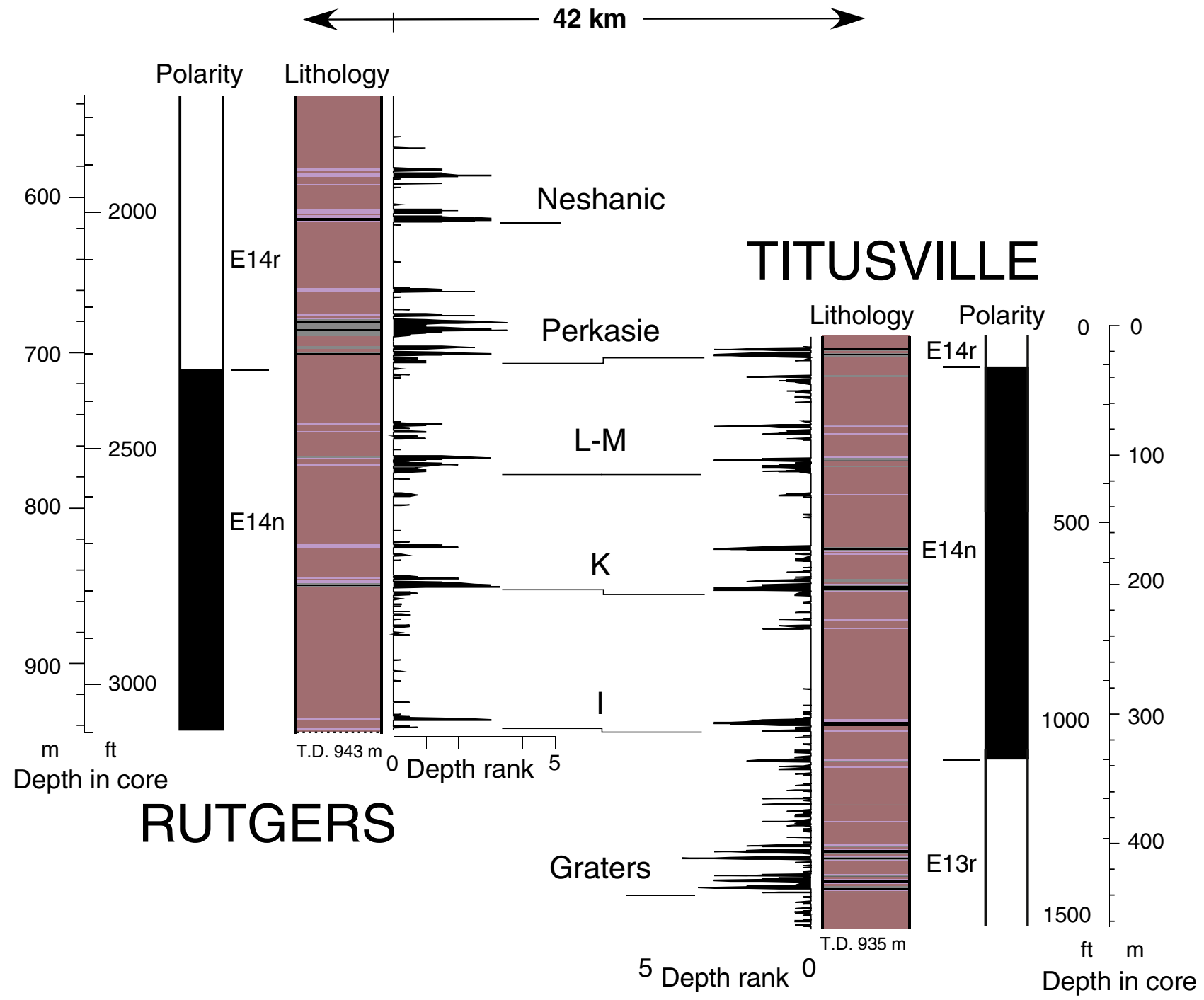

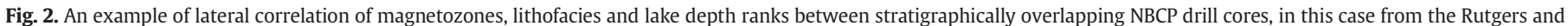
Titusville sites that are separated by 42 km (Kent et al., 1995; Olsen et al., 1996a).

the CAMP lavas (Prevot and McWilliams, 1989); the next thickest ones are H25n (380 m) in the Portland Formation and E11r (304 m) $\mathrm{m}$ in the Lockatong Formation. At the opposite end of the spectrum, there are a number of magnetozones only a few meters thick: E22n.1r (1.6 m), E21r.2n (2.8 m), and notably E23r $(3.1 \mathrm{~m})$. The overall mean magnetozone thickness is $104 \mathrm{~m}$ (in Rutgers-normalized depth units for the Newark basin).

\subsection{Newark and Hartford orbital climate cycles}

The Newark, Hartford and other Eastern North American rift basins were occupied by very large playa to perennial lakes during their long histories (Olsen, 1990). Lacustrine deposits characterize virtually all but the basal (fluvial) Stockton Formation of the Newark basin including the sedimentary units interbedded with and overlying the CAMP volcanics in both the Newark and Hartford basins, with the exception of the uppermost strata of the latter. These lacustrine sediments display a pronounced cyclic variation in lithofacies (Olsen, 1986; Van Houten, 1964). The cyclicity can be characterized by facies or depth ranks, a measure of lake depth based on a classification of water-depth-related sedimentary facies suitable for numerical analysis (Olsen, 1986; Olsen and Kent, 1996). To a less subtle extent the cyclicity is also evident in the color of the strata which reflects redox conditions of the sediments and other physical lithological characteristic as seen in instrumental natural gamma ray and sonic geophysical logs (Goldberg et al., 1994; Olsen and Kent, 1999; Reynolds, 1993).

The fundamental lithofacies variation is the Van Houten cycle, which is recognized on a stratigraphic scale of 3 to $6 \mathrm{~m}$ in the NBCP cores (Fig. 4). This cycle was hypothesized (Van Houten, 1964) and confirmed (Olsen, 1986; Olsen and Kent, 1996) to correspond to lake level (i.e., climate) change at a precessional periodicity (nominal $20 \mathrm{kyr}$, modeled as roughly $5 \%$ shorter than today's 21 kyr average period because of recession of the Moon; Berger et al., 1992). The expression of Van Houten cyclicity is modulated by several orders of orbital eccentricity variations, most prominently by the $405 \mathrm{kyr}$ long eccentricity orbital variation expressed as the McLaughlin cycle (Olsen, 1986; Olsen and Kent, 1996) as well as the short and very long eccentricity variations of $\sim 100 \mathrm{kyr}$ and $\sim 1.8 \mathrm{Myr}$.

The cyclicity of varying amplitudes and periods permeates the entire lacustrine sedimentary section as evident in moving window spectral analysis (Olsen and Kent, 1999) and wavelet analysis (Fig. 5) of depth ranks even with no tuning. The multiple periodicities present change in concert with the specific thickness of the McLaughlin cycle, which is prima facie evidence of pacing by an external clock and otherwise inexplicable. Furthermore, periodic fluctuations in amplitude in higher frequencies are evident in the band of power at the appropriate lower 


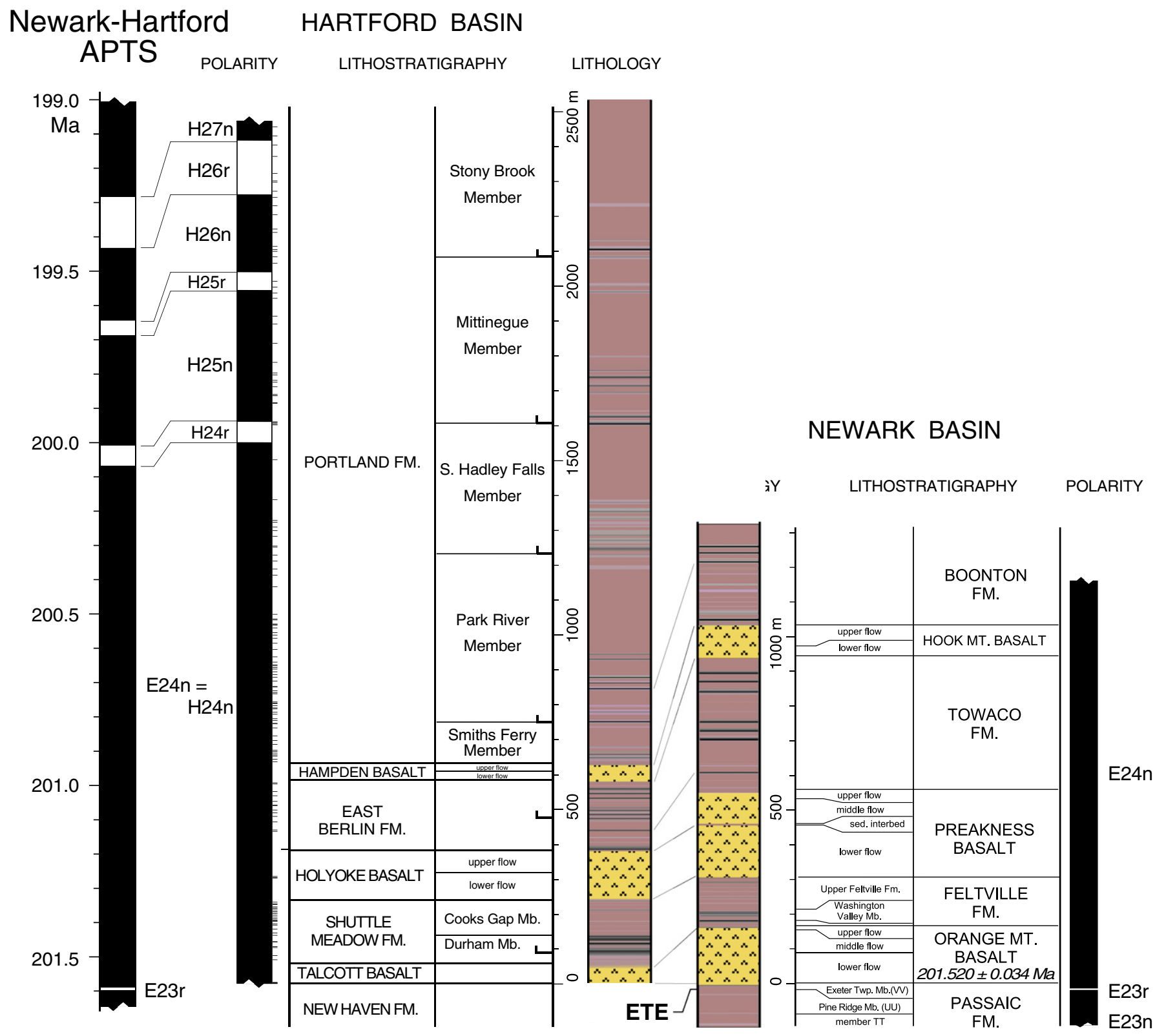

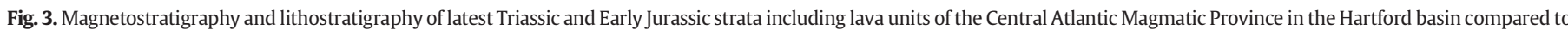

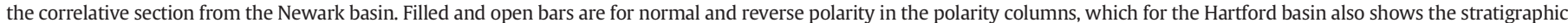

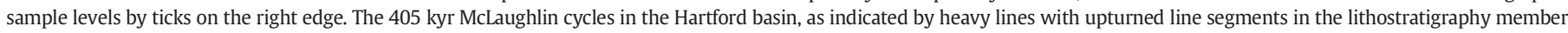

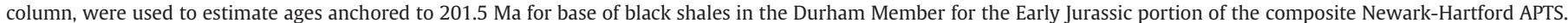
Figure is updated from Kent and Olsen (2008).

frequencies. There is strong consistent power with a period of around $60 \mathrm{~m}$ that is present throughout, even if it is faint in the upper $800 \mathrm{~m}$ of the section where the depth ranks are muted. This is the McLaughlin cycle, which is a robust lithologic variation that effectively corresponds to mappable lithostratigraphic members in the Lockatong Formation and most of the Passaic Formation in the Newark basin as well as most of the Portland Formation of the Hartford Basin. This practice follows the basic pattern laid down by D. B. McLaughlin (McLaughlin, $1943,1945,1959)$ for which the cycle is named. Simply setting the duration of the Upper Stockton, Lockatong and Passaic Formations as most probably longer than $10 \mathrm{Myr}$ and $<30 \mathrm{Myr}$ makes it possible to associate the spectral peak at around $60 \mathrm{~m}$ wavelength with the long (405 kyr) orbital eccentricity cycle.

There is notable power at other periodicities as well (e.g., at around $20 \mathrm{~m}$ ) such that the overall spectrum of frequency variations makes a very compelling case for Milankovitch climate forcing. For example, a comparison of the average power spectrum of depth ranks for the Lockatong Formation to the spectrum of expected climate forcing in the tropics from modern orbital changes (Laskar et al., 2011) shows a remarkable parallel in the family of eccentricity peaks (twin peaks at around $100 \mathrm{kyr}$, and a single peak at around $400 \mathrm{kyr}$ ) (Fig. 6). This pattern supports the interpretation of associating the McLaughtlin cycle with the 405 kyr eccentricity variation, the largest and most stable term in the approximation of eccentricity of Earth's orbital variations on geologic time-scales (Berger et al., 1992; Laskar, 1990; Laskar et al., 2004, 2011). The virtual absence of any power that would correspond to an obliquity cycle is noteworthy and greatly simplifies the interpretation of the pattern of climate forcing in these sediments.

We use the $405 \mathrm{kyr}$ McLaughlin cycle to generate a relative chronology for the Late Triassic and earliest Jurassic polarity sequence from the 
VAN HOUTEN CYCLE (Towaco Fm., Hettangian: ACE core PT-14)

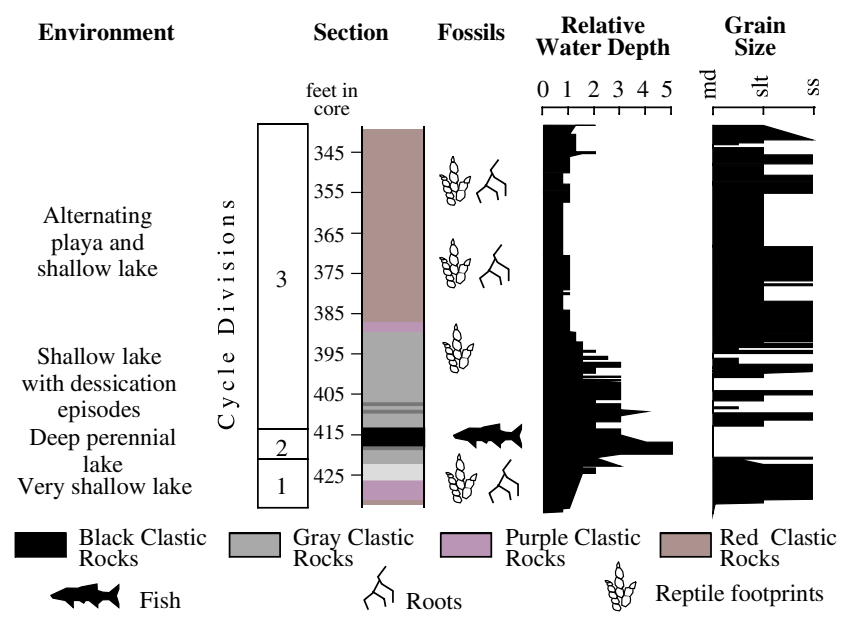

CYCLE HIERARCHY

(Passaic Fm., Norian: Somerset no. 2 core)

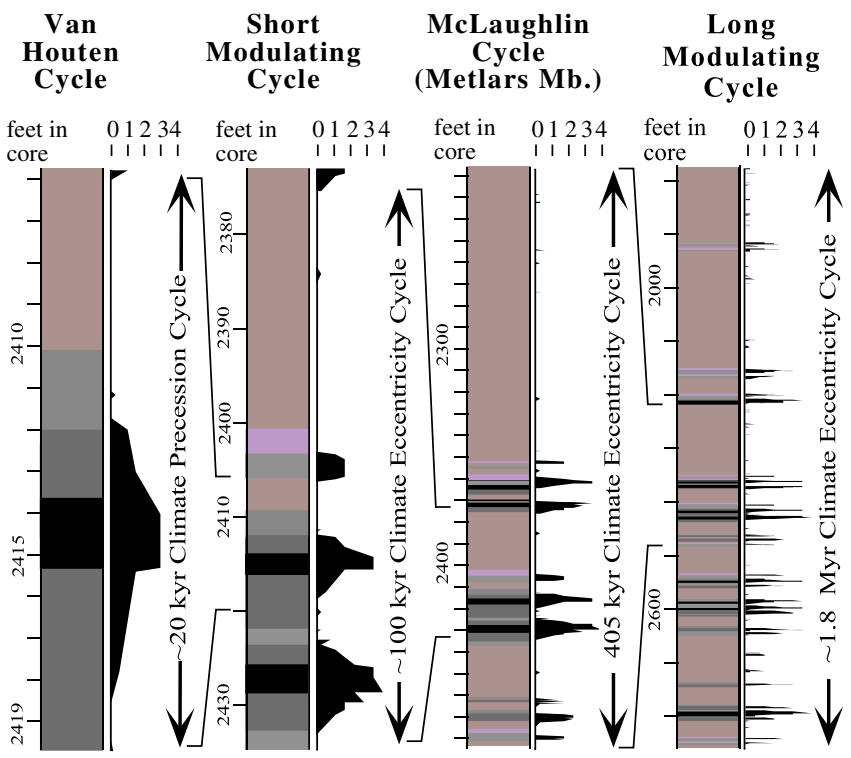

Fig. 4. Van Houten and longer modulating lacustrine cycle types of the Newark basin. A. The fundamental Van Houten cycle (example based on section in ACE core PT-14 in New Jersey). B. Van Houten cycle and the nested short, McLaughlin, and long modulating cycles of the lacustrine rocks of the Newark basin illustrating the method of member delineation using as an example the Metlars Member of the Passaic Formation as seen in the NBCP Somerset no. 2 core. Figure adapted from Olsen et al. (1996a, 1996b).

Newark and Hartford basins. In the uppermost Stockton, Lockatong and Passaic formations of the Newark basin, there are 60 McLaughlin cycles averaging $62 \mathrm{~m}$ in thickness (Kent and Olsen, 1999; Olsen and Kent, 1996). Coinciding with and following the emplacement of the CAMP volcanics, McLaughlin cycles become much thicker, on the order of $400 \mathrm{~m}$. This thickening is seen in the Feltville and Towaco Formations of the Newark basin and the Shuttle Meadow and East Berlin Formations of the Hartford Basin interbedded with the volcanics, as well as in the Boonton and Portland formations overlying the extrusive intervals in the Newark and Hartford basins, respectively (Kent and Olsen, 2008).

McLaughlin cycles are lithological units with boundaries defined by specific beds. The convention employed in designating them is to place the base of the McLaughlin cycle at the first well-developed and mappable darker-colored bed (generally gray or black) producing an asymmetrical-looking cycle (Olsen et al., 1996a) (Fig. 4VH). As a consequence, the base of each McLaughlin cycle does not conform exactly to the peak of a $405 \mathrm{kyr}$ cycle, when the amplitude of lake depth changes from precessional variations would be the greatest, but rather tends to be offset below it by two or more precessional cycles. However, the effect is not cumulative and there is essentially no net effect over multiple cycles in the chronology because the offsets tend to be systematic.

\subsection{Astrochronological age model anchored by U-Pb dates}

As a framework for a global geologic and polarity time-scale, the astrochronology of the Newark-Hartford composite sequence needs to be anchored to a datum of known age in millions of years before present. The best-dated levels that can be directly tied to this magnetic reversal and orbital sequence are high-precision $\mathrm{U}-\mathrm{Pb}$ zircon dates from CAMP rocks in the Newark basin (Blackburn et al., 2013). Of particular utility is the date of $201.520 \pm 0.034$ Ma for the Palisade Sill, which is linked to the Orange Mountain Basalt, the oldest series of CAMP lavas in the Newark basin. A thin reverse polarity magnetozone (E23n.1r) was found about $20 \mathrm{~m}$ below the Orange Mountain Basalt in the initial sampling of the Martinsville NBCP core (Kent et al., 1995) and soon afterwards confirmed $>100 \mathrm{~km}$ away in the fossiliferous Grist Mill section of the Jacksonwald Syncline (Fig. 27 in Olsen et al. (1996a)), where it had been narrowly missed between outcrop sites TJJ and TJR of Witte et al. (1991) but was subsequently identified at Grist Mills and the adjacent Exeter section about $1 \mathrm{~km}$ to the east (Olsen et al., 2002b). Elevated in rank and renamed E23r, the reverse polarity magnetozone was more precisely delineated in the Martinsville NBCP core with higher density sampling (Kent and Olsen, 1999).

To register these $\mathrm{U}-\mathrm{Pb}$ dated basalt flows and associated magnetic polarity zones into the $405 \mathrm{kyr}$ McLaughlin-cycle-based astrochronology, it is necessary to use a finer-scale approach to the astrochronology of the lacustrine strata interbedded with and surrounding the basalt units because the counterparts to McLaughlin cycles are themselves segmented by the flows. It has been clear since the 1980s (e.g., Olsen, 1980, 1986) that the overall hierarchy of cycles seen in the Passaic Formation continues into the overlying strata and is in fact amplified to a remarkable extent.

At the largest scale, Van Houten cycles with the best-developed microlaminated deeper-water units (with abundant articulated fossil fish) occur in three intervals in the sedimentary strata bounding and interbedded with the CAMP lava flows. The lowest interval is in the Washington Valley Member of the Feltville Formation. The next higher interval is in the middle Towaco Formation, and the uppermost interval with well-developed Van Houten cycles is in the Boonton Formation as seen in the ACE cores. These deeper-water units have been interpreted as occurring at times of maximum precessional variability and hence at the peaks in eccentricity of the $\sim 100 \mathrm{kyr}$ cycle coinciding with the peak of the 405 kyr cyclicity (Olsen and Kent, 1996). Other clusters of laminated dark mudstones in Van Houten cycles occur on both sides of each of these peaks and demarcate lesser peaks in the $\sim 100$ kyr cycles. Intervals of very poorly developed Van Houten cycles nearly lacking gray or black beds occur in the lower, but not lowest Boonton Formation, the upper, but not uppermost Feltville Formation and just below the uppermost few tens of meters of the Passaic Formation. These intervals correspond to troughs in precessional variability and hence troughs in the 405 kyr eccentricity cycle.

The lowest McLaughlin cycle associated with the CAMP is thus split by the Orange Mountain Basalt into a lower part with the underlying Exeter Twp. Member (=Member VV) and an upper part with the overlying Washington Valley Member, making these two members conceptually different from the lithostratigraphic members of the rest of the Passaic Formation. Likewise, the next McLaughlin cycle has the Preakness Basalt nearly at where its base would be otherwise drawn, and the Hook Mountain Basalt occurs nearly exactly at the top of the same McLaughlin cycle. This approach has been used consistently for 

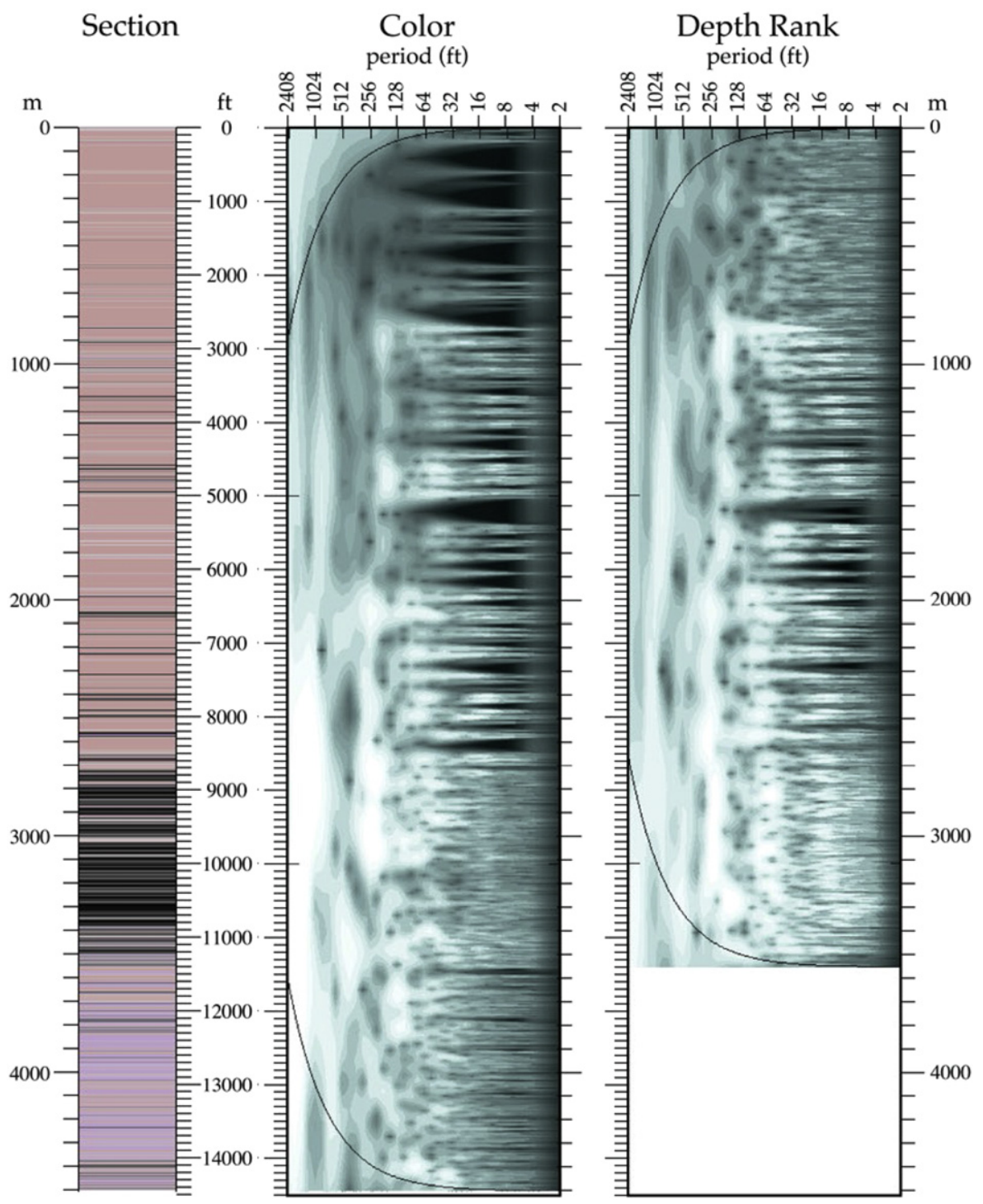

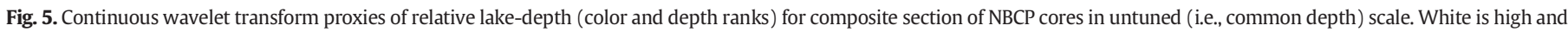

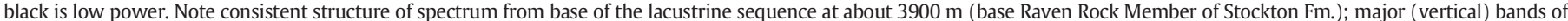

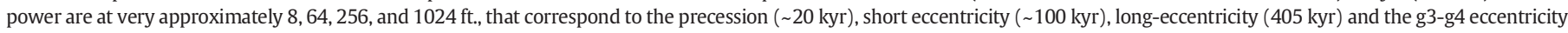

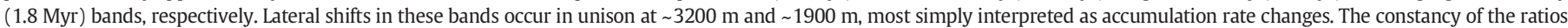

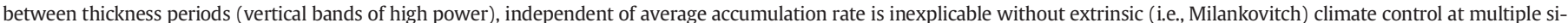
multaneous periods. Analyses were conducted using Matlab wavelet script provided by C. Torrence and G. Compo (http://paos.colorado.edu/research/wavelets/).

the last 20 years for the CAMP-related deposits and to estimate the duration of the CAMP events (Blackburn et al., 2013; Kent and Olsen, 2008; Olsen et al., 1996b, 2003; Whiteside et al., 2007).

All of the variation amongst the Van Houten cycles seen in the strata around and in the CAMP lava flow interval fits relatively easily within two successive $405 \mathrm{kyr}$ cycles, providing the basis for a $20 \mathrm{kyr}-\mathrm{level}$ astrochronology (Olsen et al., 1996b; Whiteside et al., 2007) that was tested and well corroborated by high-precision zircon U-Pb zircon dates by Blackburn et al. (2013). Given this astrochronology, with the peaks of the 405 kyr cycles pegged at the Washington Valley Member and the middle Towaco Formation, the rest of the Newark basin astrochronology can be calibrated and the magnetostratigraphy directly linked with it, as follows, to derive APTS.

At the Exeter outcrop section in the Jacksonwald Syncline, which contains rich litho-, chemo-, and biostratigraphic signals of environmental changes (Olsen et al., 2002b, 2011; Whiteside et al., 2010), the base of E23r is found to be closely aligned with the base of the Exeter Twp. Member (Fig. 7). Chron E23r encompasses about $1 / 2(\sim 11 \mathrm{kyr})$ of a Van Houten precession cycle between the base of the Exeter Twp.
Member and a gray mudstone containing evidence from sporomorphs for the ETE, which at Jacksonwald is estimated to occur $14 \mathrm{kyr}$ before the Orange Mountain Basalt or $20 \mathrm{kyr}$ after the beginning of Chron E23r. The onset of Chron E23r is thus estimated from astrochronology to be 34 kyr before the Orange Mountain Basalt. Although conveniently situated as a mappable unit with respect to Chron E23r, the ETE, and the Orange Mountain Basalt, the Exeter Twp. Member, as described above, is actually not the next McLaughlin cycle after the Park Ridge Member (=member UU); that role is assigned to the Washington Valley Member whose base is equivalent to about one short eccentricity cycle above the base of the Exeter Twp. Member. In terms of calibration (with the ages to the nearest $0.10 \mathrm{Myr}$ ), the base of the Washington Valley Member can thus be set to $201.50 \mathrm{Ma}$, making the base of the Exeter Twp. Member and coincident Chron E23r at 201.60 Ma.

If the $405 \mathrm{kyr}$ orbital cycle is indeed stable over geological timescales and the U-Pb geochronology is accurate within analytical uncertainties, the base of the Washington Valley Member, a gray and black thin-bedded mudstone corresponding to relatively high lake level and picked to coincide close to a local long eccentricity (Ecc405) maximum, 


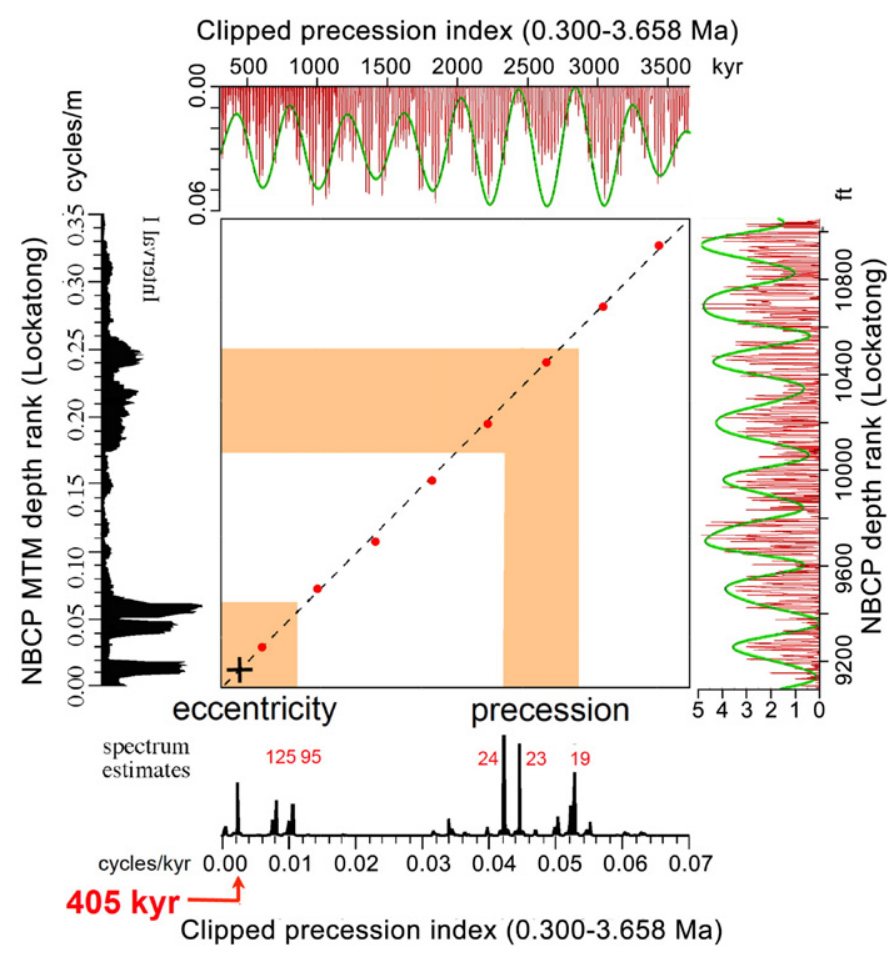

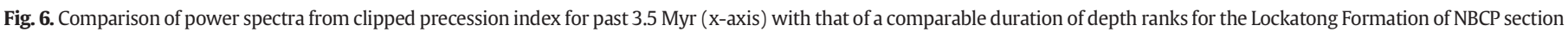

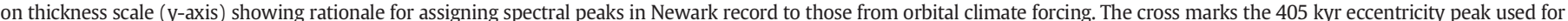
construction of a time-scale.

should be in phase with an eccentricity maximum of an Ecc405 cycle projected back by the nearest integer number from the most recent calculated eccentricity maximum. An eccentricity maximum $(\mathrm{k}=1)$ last occurred at $0.216 \mathrm{Ma}$ (Laskar et al., 2004) (Fig. 8). The base of the Washington Valley Member should therefore have occurred in the maximum eccentricity phase of cycle Ecc405:k, where

$(\mathrm{k}-1)=(201.5-0.216) / 0.405 ; \mathrm{k}=497.998$

This estimate of $\mathrm{k}$ is remarkably close, indeed virtually identical to an integer value expected for being in the same phase of long eccentricity counting down from the present. Departures from an integer value of $\mathrm{k}$ for the Washington Valley Member could occur for any number of reasons, from uncertainties of the U-Pb dating $( \pm 0.034 \mathrm{Myr}$ at $95 \%$ confidence), uncertainties in estimates of sedimentation and lava extrusion rates used to extrapolate the $\mathrm{U}-\mathrm{Pb}$ date to the base of the overlying Washington Valley Member, or the possibility that the laminated units used to delineate the base of the Washington Valley Member occurred one or more precession cycles from the peak eccentricity. There may even be a very small change in the Ecc405 period. However, the close correspondence in phase of the U-Pb-derived date and that calculated for the Ecc405 cycle at the Washington Valley Member suggests that

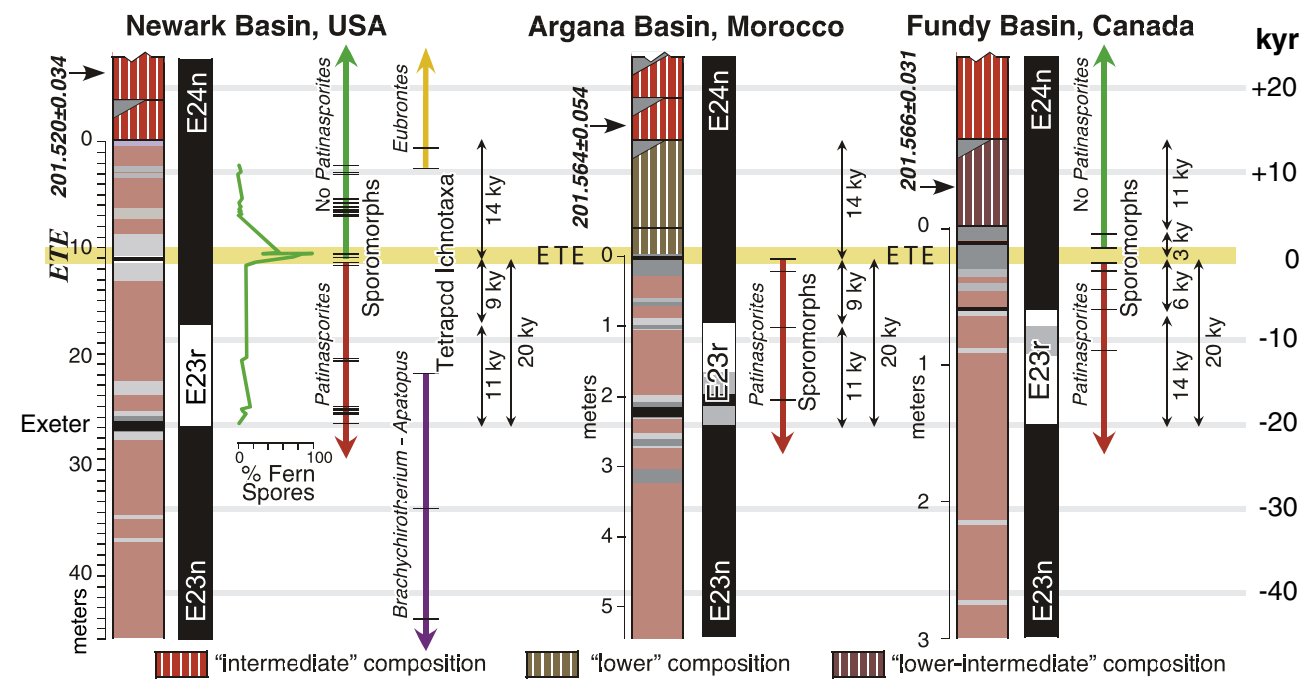

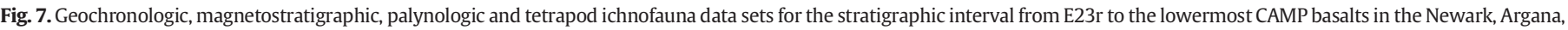

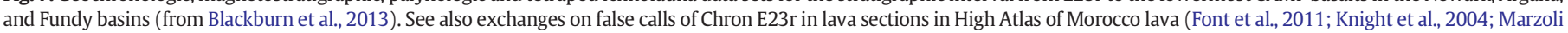
et al., 2004, 2008; Whiteside et al., 2007, 2008). 


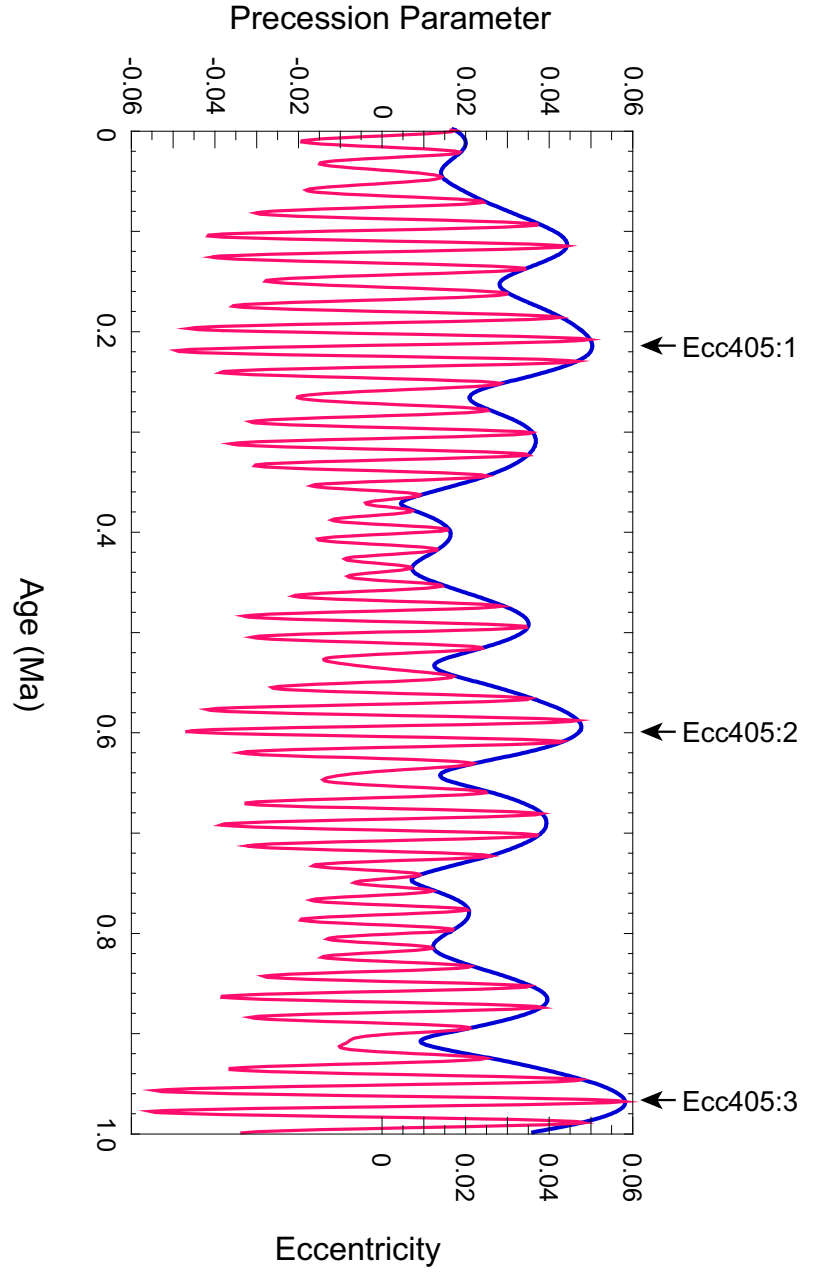

Fig. 8. Eccentricity and precession parameter for past $1000 \mathrm{kyr}$ (Paillard et al., 1996) showing successively older 405 kyr eccentricity maxima (Ecc405:1, Ecc405:2, Ecc405:3, etc.). The nomenclature (Ecc405:k) is extended back into the Triassic assuming the period stays constant at $405 \mathrm{kyr}$.

the total uncertainty counting back from the present should amount to no more than plus or minus only one full $405 \mathrm{kyr}$, within the uncertainty of $<0.2 \%$ cited for the Mesozoic Era (Laskar et al., 2004).

\section{Notes to Table 2}

Stratigraphic levels (arbitrarily made negative for Newark basin where scaled to the Rutgers NBCP core and positive in Hartford basin) measured with respect to the base of the Orange Mountain Basalt (and equivalent Talcott Basalt) of the bases of the lithologic members and formations and McLaughlin (McL) cycles. Members that represent McLaughlin cycles are numbered from 0 for the Shuttle Meadow + East Berlin/ Washington Valley Member downward to +60 for the lowest Raven Rock member (RaR-8) of the Stockton Formation in the Newark basin and upward to -5 for the Stony Brook Member of the Portland Formation in the Hartford basin. McLaughlin cycles are assumed to be manifestations of the long (405 kyr) orbital eccentricity cycle; the defined base of each member as McLaughlin cycle is assumed to be in more or less consistent phase with a peak of the 405 kyr orbital eccentricity cycle (Ecc405), which are counted back $(\mathrm{k})$ from the most recent peak $(\mathrm{k}=1)$ at $0.216 \mathrm{Ma}$ (Fig. 8). Age (Ma) = $0.216+(\mathrm{k}-1) * 0.405$; age of lowest recovered Stockton Formation in Princeton NBCP core is estimated by extrapolation of sediment accumulation rate for RaR-1 to RaR-8. Values for stratigraphic levels in the Hartford basin have been modified from Kent and Olsen (2008) by a section added to the East Berlin Formation from cores BD 227A and 255 from Steinen et al. (2015), which added a net $34.07 \mathrm{~m}$ to the basal East Berlin and overlying section (see Fig. 3) but with no change to the astrochronological ages of member boundaries. Age in bold (201.5 Ma) is calibration age for APTS assigned to base of Washington Valley Member (Ecc405:498.0) from high-precision U-Pb zircon date of immediately underlying Orange Mountain Basalt, whose age along with those for ETE and Exeter Twp. Member are shown in italics because these ages are interpolated within a McLaughlin cycle (Ecc405:498).
Table 2

Lithologic members as McLaughlin 405 kyr eccentricity cycles in the Newark-Hartford succession for the Late Triassic-Early Jurassic.

\begin{tabular}{|c|c|c|c|c|}
\hline Member & Level (m) & McL & Ecc405 (k) & Age (Ma) \\
\hline Stony Brook & 2081.8 & -5 & 493 & 199.48 \\
\hline Mittinegue & 1602.9 & -4 & 494 & 199.88 \\
\hline S. Hadley Falls & 1228.5 & -3 & 495 & 200.29 \\
\hline Park River & 747.2 & -2 & 496 & 200.69 \\
\hline Upper East Berlin + & & & & \\
\hline Smiths Ferry & 504.8 & -1 & 497 & 201.10 \\
\hline $\begin{array}{l}\text { Shuttle Meadow + } \\
\text { Lower East Berlin/ }\end{array}$ & & & & \\
\hline Washington Valley & 81.0 & 0 & 498 & 201.50 \\
\hline Orange Mountain Basalt & 0.0 & 0.16 & 498.16 & 201.57 \\
\hline ETE & -5.2 & 0.19 & 498.20 & 201.58 \\
\hline Exeter Twp. (VV) & -12.3 & 0.25 & 498.25 & 201.60 \\
\hline Pine Ridge (UU) & -59.4 & 1 & 499 & 201.91 \\
\hline TT & -124.7 & 2 & 500 & 202.31 \\
\hline SS & -186.5 & 3 & 501 & 202.72 \\
\hline $\mathrm{RR}$ & -241.3 & 4 & 502 & 203.12 \\
\hline QQ & -307.0 & 5 & 503 & 203.53 \\
\hline $\mathrm{PP}$ & -360.1 & 6 & 504 & 203.93 \\
\hline $\mathrm{OO}$ & -429.8 & 7 & 505 & 204.34 \\
\hline NN & -489.1 & 8 & 506 & 204.74 \\
\hline MM & -543.8 & 9 & 507 & 205.15 \\
\hline LL & -600.7 & 10 & 508 & 205.55 \\
\hline KK & -651.0 & 11 & 509 & 205.96 \\
\hline Flemington (JJ) & -728.3 & 12 & 510 & 206.36 \\
\hline II & -785.7 & 13 & 511 & 206.77 \\
\hline Ukrainian (HH) & -840.6 & 14 & 512 & 207.17 \\
\hline Cedar Grove (GG) & -898.9 & 15 & 513 & 207.58 \\
\hline $\mathrm{FF}$ & -969.6 & 16 & 514 & 207.98 \\
\hline $\mathrm{EE}$ & -1034.2 & 17 & 515 & 208.39 \\
\hline $\mathrm{DD}$ & -1074.9 & 18 & 516 & 208.79 \\
\hline $\mathrm{CC}$ & -1140.6 & 19 & 517 & 209.20 \\
\hline BB & -1199.3 & 20 & 518 & 209.60 \\
\hline $\mathrm{AA}$ & -1244.6 & 21 & 519 & 210.01 \\
\hline Z & -1285.7 & 22 & 520 & 210.41 \\
\hline Y & -1362.5 & 23 & 521 & 210.82 \\
\hline Metlars (Z) & -1419.8 & 24 & 522 & 211.22 \\
\hline Livingston (Y) & -1478.3 & 25 & 523 & 211.63 \\
\hline Kilmer (X) & -1518.9 & 26 & 524 & 212.03 \\
\hline $\mathrm{U}$ & -1598.6 & 27 & 525 & 212.44 \\
\hline $\mathrm{T}$ & -1677.8 & 28 & 526 & 212.84 \\
\hline S & -1730.8 & 29 & 527 & 213.25 \\
\hline $\mathrm{R}$ & -1785.7 & 30 & 528 & 213.65 \\
\hline Q & -1847.1 & 31 & 529 & 214.06 \\
\hline Neshanic (P) & -1947.9 & 32 & 530 & 214.46 \\
\hline Perkasie & -2033.4 & 33 & 531 & 214.87 \\
\hline L-M & -2105.4 & 34 & 532 & 215.27 \\
\hline $\mathrm{K}$ & -2185.2 & 35 & 533 & 215.68 \\
\hline I & -2270.2 & 36 & 534 & 216.08 \\
\hline Graters & -2375.1 & 37 & 535 & 216.49 \\
\hline $\mathrm{E}-\mathrm{F}$ & -2443.5 & 38 & 536 & 216.89 \\
\hline Warford Brook & -2522.7 & 39 & 537 & 217.30 \\
\hline C & -2623.2 & 40 & 538 & 217.70 \\
\hline Walls Island & -2708.2 & 41 & 539 & 218.11 \\
\hline Tumble Falls & -2781.1 & 42 & 540 & 218.51 \\
\hline Smiths Corner & -2860.4 & 43 & 541 & 218.92 \\
\hline Prahls Island & -2938.9 & 44 & 542 & 219.32 \\
\hline Tohicken & -3007.4 & 45 & 543 & 219.73 \\
\hline Skunk Hollow & -3091.6 & 46 & 544 & 220.13 \\
\hline Byram & -3147.5 & 47 & 545 & 220.54 \\
\hline Ewing Creek & -3203.4 & 48 & 546 & 220.94 \\
\hline Nursery & -3251.0 & 49 & 547 & 221.35 \\
\hline Princeton & -3304.6 & 50 & 548 & 221.75 \\
\hline Scudders Falls & -3368.3 & 51 & 549 & 222.16 \\
\hline Wilburtha & -3415.9 & 52 & 550 & 222.56 \\
\hline RaR-1 & -3463.2 & 53 & 551 & 222.97 \\
\hline RaR-2 & -3506.9 & 54 & 552 & 223.37 \\
\hline RaR-3 & -3542.6 & 55 & 553 & 223.78 \\
\hline RaR-4 & -3583.1 & 56 & 554 & 224.18 \\
\hline RaR-5 & -3624.8 & 57 & 555 & 224.59 \\
\hline RaR-6 & -3654.5 & 58 & 556 & 224.99 \\
\hline RaR-7 & -3698.1 & 59 & 557 & 225.40 \\
\hline RaR-8 & -3739.1 & 60 & 558 & 225.80 \\
\hline Stockton lowest & -4400.9 & & & 232.57 \\
\hline
\end{tabular}


We elect to maintain a period of $405 \mathrm{kyr}$ for Ecc405 and assign an age of 201.5 Ma for the base of the Washington Valley Member as Ecc405:498 and an age of 201.6 Ma for the base of Chron E23r. We believe that our astrochronological age estimate for the base of the Washington Valley Member and the inferred age of Chron E23r do not violate any age constraints within their probable estimates of uncertainty determined by Blackburn et al. (2013). The previously identified McLaughlin cycles in the tabulation of Kent and Olsen (1999) are renumbered such that McL \#60 is RaR-8 in the Raven Rock, which becomes Ecc405:558, McL \#59 is RaR-7 in the Raven Rock, which becomes Ecc405:557, and so forth up to McL \#0, the Washington Valley Member, which becomes Ecc405:498 from the Newark basin. The renumbering continues in the Early Jurassic of the Hartford basin (Kent and Olsen, 2008) from the Upper Berlin Fm + Smiths Ferry Member (Ecc405:497), Park River Member (Ecc405:496), and up to the Stony Brook Member (Ecc405:493).

The Ecc405:k designations are converted to time in millions of years ago according to:

Age $(\mathrm{Ma})=(\mathrm{k}-1) * 0.405+0.216$

These ages are listed in Table 2.

A plot of cumulative member thickness versus age shows a generally smooth progression of slopes (i.e., sediment accumulation rates) through the Triassic part of the Newark basin section (Fig. 9). In the upper part of the composite section, however, there is an abrupt increase in sediment accumulation rate by nearly an order of magnitude at around the emplacement of CAMP volcanics. Accumulation rates are from 100 to $150 \mathrm{~m} / \mathrm{Myr}$ in the Late Triassic in the Newark basin and increase to around $1000 \mathrm{~m} / \mathrm{Myr}$ in the Early Jurassic of the Hartford basin and even higher in the thicker, stratigraphically overlapping portion of the Newark basin. Assuming that accumulation rates were linear within each 405 kyr McLaughlin cycle, the ages of magnetozone boundaries from E8r to H27n (Kent and Olsen, 1999) (Kent and Olsen, 2008) were interpolated accordingly. In the absence of discernible cyclicity

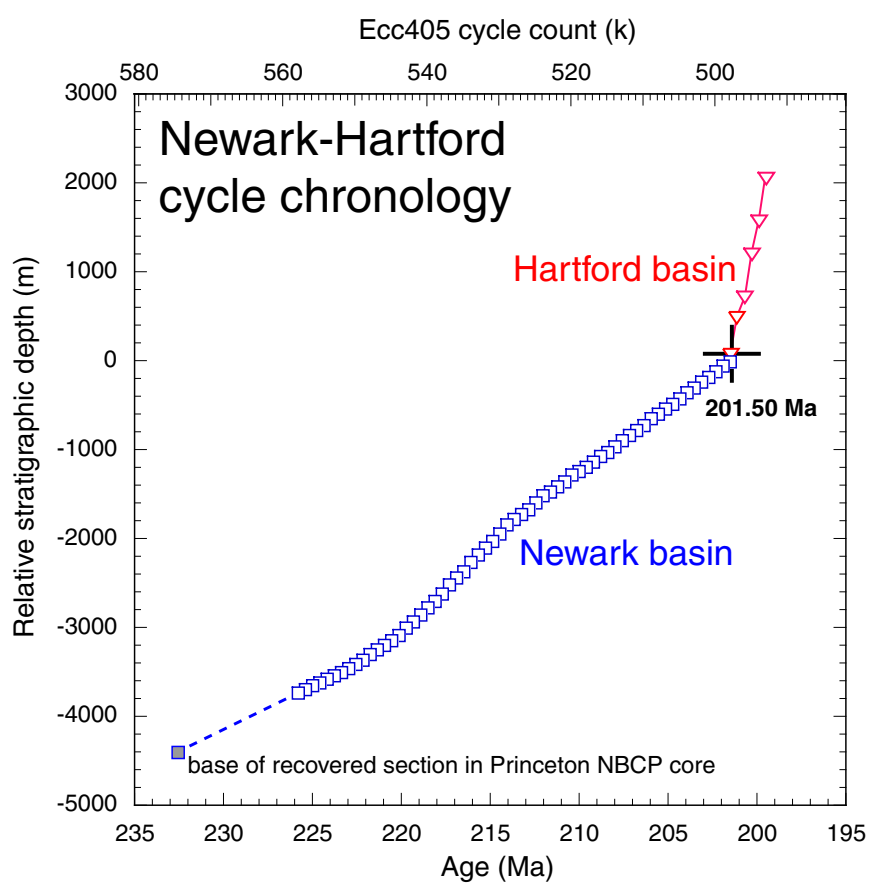

Fig. 9. Depth-age model for the Newark basin and the extrusive zone of the Hartford basin based on using $405 \mathrm{kyr}$ for lithologic members recognized as McLaughlin cycles and anchored to an age of 201.50 Ma for the base of the Washington Valley Member of the Feltville Formation, just above the first CAMP lava unit (Orange Mountain Basalt) in the Newark basin. in the more fluvial facies of the lower part of the Stockton Formation, the average sediment accumulation rate $(97.7 \mathrm{~m} / \mathrm{Myr})$ for the 8 cycles in the Rock Raven unit in the upper part of the Stockton Formation was used to construct an age model for the subjacent $700 \mathrm{~m}$ of Newark basin section and to extrapolate ages of magnetozones E1r to E8r.

The complete APTS extends from 232.57 Ma (oldest extrapolated portion of E1r at the base of the recovered section in the Princeton NBCP core) to $199.15 \mathrm{Ma}$ (youngest extrapolated portion of $\mathrm{H} 27 \mathrm{n}$ in the Hartford basin), encompassing 33.42 Myr of record (Fig. 1). The 66 polarity interval lengths are exponentially distributed, ranging from $0.023 \mathrm{Myr}$ (Chron E23r) to 1.6 Myr (Chron E24n) with an average duration of 0.51 Myr. A listing for the Newark-Hartford APTS is given in Table 3.

\subsection{Comparison of Newark-Hartford APTS with previous time-scales}

Olsen et al. (2011) summarized the evolution of the Newark APTS from 1995 to 2010. Beside the addition of the Jurassic chrons (H24 to H27) from the Hartford basin (as described above), principal changes from the initial Newark APTS were the addition of McLaughlin cycles RaR-1 to 8 in the upper Stockton Formation and updated numerical values of the age calibration for CAMP rocks and how it was used to anchor the relative sequence. A previous tabulation of Newark magnetochrons (Kent and Olsen, 1999) listed 202.048 Ma for the base of Chron E23r, based on available dates for the Palisade Sill that were used to project a rounded age estimate of 202 Ma for the TriassicJurassic boundary (at the time thought to be the same as the endTriassic extinction, ETE) just below the Orange Mountain Basalt (as described above). The same datum was used to incorporate the Hartford magnetochrons (Kent and Olsen, 2008). Since then, U-Pb zircon dating of the North Mountain Basalt in the Fundy basin (Schoene et al., 2010) pointed to an age significantly younger than 202 Ma for the onset of CAMP volcanism. This geochronological work culminated with the comprehensive U-Pb zircon dating of CAMP rocks that confirms an age closer to 201.60 Ma for the onset of CAMP volcanism (Blackburn et al., 2013). Here we used 201.50 Ma for the base of the Washington Valley Member (Ecc405:498) with an age of 201.60 Ma (compared to 202.048 Ma) for the onset of Chron E23r (and the base of the Exeter Twp. Member) to anchor the APTS. The updated Newark-Hartford APTS is thus systematically shifted younger by about $0.5 \mathrm{Myr}$ compared to some earlier versions of the time-scale (e.g., Kent and Olsen, 1999). Moreover, biostratigraphic levels like the TJB and the ETE are now free to be dated by the U-Pb calibrated astrochronology (e.g., Blackburn et al., 2013) rather than setting the timing. For example, the Geological Time Scale 2012 (Gradstein et al., 2012) and the more recent (v. 2016/ 12) IUGS/ISC chronostratigraphic chart (www.stratigraphy.org) set the Triassic/Jurassic boundary at $201.3 \pm 0.2 \mathrm{Ma}$.

The revised Newark-Hartford APTS also eliminates an assumed 1.5 Myr gap in the record of Chron E7r that was inserted into some depictions of the time-scale (e.g., see Olsen et al., 2011). The alleged gap was based on an admittedly weak lithological correlation of cores within the Taylorsville basin and correlation of the Taylorsville composite section with the Newark basin (LeTourneau, 2003) and thought to reflect a hinge margin unconformity between tectonostratigraphic sequences II and III as seen in the Argana Basin of Morocco (Olsen, 1997). However, more recent work in the Dan River basin (Olsen et al., 2015) shows a good cross correlation with the Newark section with no gap in E7r suggesting that the Newark and Dan River basins records preserve the correlative conformity of the sequence boundary, should it exist, and that the composite correlation in the Taylorsville basin is in error. The duration of Chron $\mathrm{E} 7 \mathrm{r}$ can be assessed independently of the Newark using the cyclicity of the Cumnock facies in the Dan River basin (Olsen et al., 2015) and the result is $<400 \mathrm{kyr}$ in all three cores that were studied. This is consistent with the extrapolation in the Princeton NBCP core from the Raven Rock Members in the Stockton Formation to Chron E7r. The original interpretation of the polarity 
sequence in the Dan River basin (Kent and Olsen, 1997) holds up completely and any change in the accumulation rate in the Stockton Formation must be below Chron E7r. Additional paleomagnetic data with cycle stratigraphic control would be useful to confirm and refine the polarity pattern for the basal fluvial part of the Stockton Formation

Table 3

Newark-Hartford APTS constrained by U-Pb zircon ages for CAMP.

\begin{tabular}{|c|c|c|c|c|}
\hline Chron & Level (m) & McL & Ecc405 (k) & Age (Ma) \\
\hline $\mathrm{H} 27 \mathrm{n}$ & 2421.0 & -5.81 & 492.19 & 199.15 \\
\hline $\mathrm{H} 26 \mathrm{r}$ & 2266.6 & -5.44 & 492.56 & 199.30 \\
\hline $\mathrm{H} 26 n$ & 2042.7 & -4.92 & 493.08 & 199.51 \\
\hline $\mathrm{H} 25 \mathrm{r}$ & 1991.6 & -4.81 & 493.19 & 199.55 \\
\hline $\mathrm{H} 25 \mathrm{n}$ & 1613.0 & -4.02 & 493.98 & 199.87 \\
\hline $\mathrm{H} 24 \mathrm{r}$ & 1554.1 & -3.87 & 494.13 & 199.93 \\
\hline$O M B$ & 0.0 & 0.16 & 498.16 & 201.57 \\
\hline $\mathrm{H} 24 \mathrm{n}=\mathrm{E} 24 \mathrm{n}$ & -10.7 & 0.22 & 498.22 & 201.59 \\
\hline $\mathrm{E} 23 \mathrm{r}$ & -13.8 & 0.25 & 498.25 & 201.60 \\
\hline E23n & -152.4 & 2.45 & 500.45 & 202.49 \\
\hline E22r & -197.7 & 3.20 & 501.20 & 202.80 \\
\hline $\mathrm{E} 22 \mathrm{n} .2 \mathrm{n}$ & -230.9 & 3.78 & 501.79 & 203.03 \\
\hline E22n.1r & -232.6 & 3.81 & 501.81 & 203.04 \\
\hline E22n.1n & -288.4 & 4.72 & 502.72 & 203.41 \\
\hline E21r.3r & -333.3 & 5.49 & 503.49 & 203.73 \\
\hline E21r.2n & -336.1 & 5.55 & 503.55 & 203.75 \\
\hline E21r.2r & -353.6 & 5.88 & 503.88 & 203.88 \\
\hline E21r.1n & -359.9 & 6.00 & 504.00 & 203.93 \\
\hline E21r.1r & -392.4 & 6.46 & 504.46 & 204.12 \\
\hline E21n & -476.6 & 7.78 & 505.77 & 204.65 \\
\hline E20r.2r & -665.2 & 11.18 & 509.18 & 206.03 \\
\hline E20r.1n & -671.9 & 11.27 & 509.27 & 206.07 \\
\hline E20r.1r & -705.5 & 11.71 & 509.70 & 206.24 \\
\hline E20n & -728.3 & 12.00 & 510.00 & 206.36 \\
\hline E19r & -822.5 & 13.69 & 511.69 & 207.05 \\
\hline E19n & -843.4 & 14.06 & 512.06 & 207.20 \\
\hline E18r & -898.6 & 15.01 & 513.01 & 207.58 \\
\hline E18n & -989.6 & 16.31 & 514.31 & 208.10 \\
\hline E17r & -1183.4 & 19.73 & 517.73 & 209.49 \\
\hline E17n & -1237.9 & 20.87 & 518.87 & 209.95 \\
\hline E16r & -1269.3 & 21.60 & 519.60 & 210.25 \\
\hline E16n & -1522.6 & 26.05 & 524.05 & 212.05 \\
\hline E15r.2r & -1584.3 & 26.82 & 524.82 & 212.36 \\
\hline E15r.1n & -1590.5 & 26.90 & 524.90 & 212.40 \\
\hline E15r.1r & -1631.2 & 27.41 & 525.41 & 212.60 \\
\hline E15n & -1756.6 & 29.47 & 527.47 & 213.44 \\
\hline E14r & -2044.2 & 33.15 & 531.15 & 214.92 \\
\hline E14n & -2289.8 & 36.19 & 534.19 & 216.16 \\
\hline E13r & -2459.4 & 38.20 & 536.20 & 216.97 \\
\hline E13n.2n & -2664.3 & 40.48 & 538.48 & 217.89 \\
\hline E13n.1r & -2671.4 & 40.57 & 538.57 & 217.93 \\
\hline E13n.1n & -2772.0 & 41.87 & 539.87 & 218.46 \\
\hline E12r & -2933.4 & 43.93 & 541.93 & 219.29 \\
\hline E12n & -2962.8 & 44.35 & 542.35 & 219.46 \\
\hline E11r & -3266.9 & 49.31 & 547.31 & 221.47 \\
\hline E11n & -3305.1 & 49.99 & 547.99 & 221.75 \\
\hline E10r & -3382.4 & 51.22 & 549.22 & 222.24 \\
\hline E10n & -3430.4 & 52.43 & 550.43 & 222.74 \\
\hline E9r & -3559.7 & 55.57 & 553.57 & 224.01 \\
\hline E9n & -3613.9 & 56.88 & 554.88 & 224.54 \\
\hline E8r & -3773.6 & & & 226.15 \\
\hline E8n & -3832.4 & & & 226.75 \\
\hline E7r & -3868.3 & & & 227.12 \\
\hline E7n & -3993.9 & & & 228.41 \\
\hline E6r & -4028.6 & & & 228.76 \\
\hline E6n & -4096.5 & & & 229.46 \\
\hline E5r & -4134.4 & & & 229.85 \\
\hline E5n.2n & -4148.6 & & & 229.99 \\
\hline E5n.1r & -4159.6 & & & 230.10 \\
\hline E5n.1n & -4198.2 & & & 230.50 \\
\hline $\mathrm{E} 4 \mathrm{r}$ & -4215.4 & & & 230.67 \\
\hline E4n & -4256.1 & & & 231.09 \\
\hline E3r & -4272.3 & & & 231.26 \\
\hline E3n & -4295.1 & & & 231.49 \\
\hline $\mathrm{E} 2 \mathrm{r}$ & -4329.6 & & & 231.84 \\
\hline $\mathrm{E} 2 \mathrm{n}$ & -4368.6 & & & 232.24 \\
\hline E1r (partim) & -4400.9 & & & 232.57 \\
\hline
\end{tabular}

in the Newark section, which is presently known only from the lower part of the Princeton NBCP core.

\section{Integration with marine sections}

Standard divisions of the Mesozoic time-scale-in this case, the Carnian, Norian, and Rhaetian stages of the Late Triassic and the Hettangian and Sinemurian epochs of the Early Jurassic-are typically delineated in marine sediments on the basis of ammonoid/ammonite or conodont biostratigraphies. With the paucity of radioisotopically dated horizons or clear Milankovitch signatures in most marine sections, magnetostratigraphy has become a powerful tool to correlate the marine sections to the Newark-Hartford APTS to develop an integrated global chronology. Marine sections in the Tethyan realm are often rich in age-diagnostic fossils and have been a favored target of magnetobiostratigraphic studies (see the comprehensive review of Triassic magnetobiostratigraphic sections in Hounslow and Muttoni (2010).

Two issues have stood out for Late Triassic time-scales: the long Carnian versus long Norian options, and the short versus long Rhaetian options. The magnetostratigraphic correlations and new age dates summarized below strongly support a relatively long Norian with a (redefined) Rhaetian of modest duration.

In the early stages of the development of what we now refer to as the Newark-Hartford APTS (Kent and Olsen, 1999; Kent et al., 1995; McIntosh et al., 1985; Witte et al., 1991), there was a reliance on palynofloral zonations for stage-level assignments (e.g., Cornet and Olsen, 1985). Moreover, some of the best available time-scales at the time made the entire Late Triassic relatively short, for example, only 21.7 Myr long, from 227.4 Ma for the base of the Carnian to 205.7 Ma for the TJB with the Carnian/Norian boundary at $220.7 \mathrm{Ma}$ and the Norian/Rhaetian boundary at 209.6 Ma in Gradstein et al. (1994). It was soon recognized that the TJB and onset of volcanism in the early part of Chron E24n was actually closer to $202 \mathrm{Ma}$ than 205.7 Ma. But for lack of better dating and means of correlation, the Carnian/Norian boundary, which in some time-scales was as young as $215 \mathrm{Ma}$ (Webb, 1981), was placed at the New Oxford-Lockatong/Lower PassaicHeidlersburg palynofloral zonal boundary (Fig. 1), more or less coincident with Chron E13 whose astrochronostratigraphic age was within the then-permissible bounds of 215 and $220 \mathrm{Ma}$. In similar fashion, the Norian/Rhaetian boundary was equated with the Lower PassaicHeidlersburg/Upper Balls Bluff-Upper Passaic palynofloral zonal boundary at around Chron E18 (ca. $208 \mathrm{Ma}$ ) whereas the base of the Carnian was left as a question mark because no pre-Carnian palynofloral elements were recognized even in the lowest part of the Newark section, giving the impression that the Carnian could be 15 Myr or longer in duration.

The breakthrough came with the magnetobiostratigraphies of Silicka Brezova (Channell et al., 2003) and Pizzo Mondello (Muttoni et al.,

Notes to Table 3

Polarity chrons are numbered upward from base of section recovered in NBCP cores to CAMP volcanics in Newark basin (E1r to E24n) and from H24n (equivalent to E24n) to $\mathrm{H} 27 \mathrm{n}$ in Hartford basin with suffix $\mathrm{n}$ for normal polarity and $\mathrm{r}$ for reverse polarity. Stratigraphic levels (arbitrarily made negative for Newark basin where scaled to the Rutgers NBCP core and positive in Hartford basin) are measured with respect to the base of the Orange Mountain Basalt (OMB) and equivalent Talcott Basalt, which is given for reference. The position of the base of each chron is also given within the nearest member as McLaughlin cycle (McL), whose base is assumed to be in more or less consistent phase with a peak of the $405 \mathrm{kyr}$ orbital eccentricity cycle. The age of each polarity chron is estimated from its fractional position in the inferred constituent 405 kyr cycle (Ecc405) counted back $(\mathrm{k})$ from its most recent peak $(\mathrm{k}=1)$ at $0.216 \mathrm{Ma}$, i.e., Age $(\mathrm{Ma})=$ $0.216+(\mathrm{k}-1) * 0.405$. Ages of polarity chrons E8r to E1 $\mathrm{r}$ (base not recovered) in lower Stockton Formation in Princeton NBCP core are estimated by extrapolation of sediment accumulation rate for RaR-1 to RaR-8. Values of the stratigraphic levels of the polarity chrons in the Hartford basin have been modified as in Table 2 but with no change in ages from Kent and Olsen (2008). 


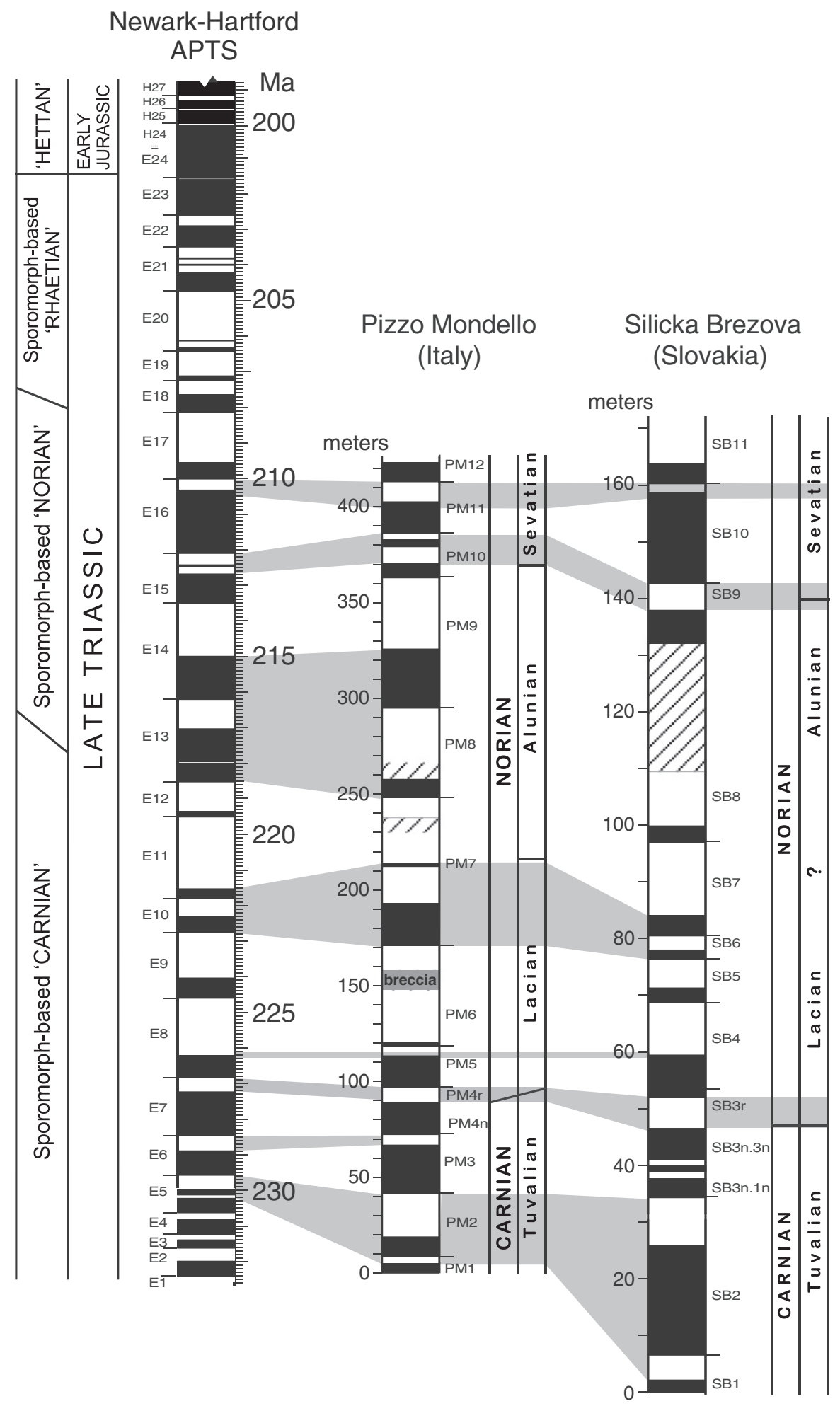

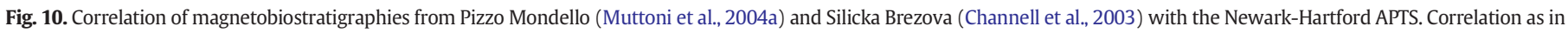

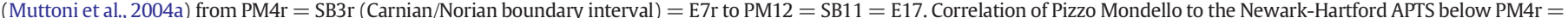

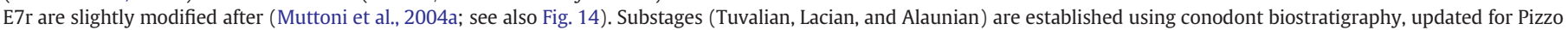
Mondello by (Mazza and Rigo, 2012). Figure modified from Olsen et al. (2011).

2004a) and their correlations to the Newark APTS (Fig. 10). Both of these independent studies correlated the conodont-based Carnian/ Norian boundary in these marine sections much further back in the Newark APTS, to Chron E7 with an astrochronostratigraphically estimated age of about $227 \mathrm{Ma}$. This immediately lengthened the duration of the Norian by 7-10 Myr at the expense of the Carnian and became the long Norian option. A subsequent astronomical cycle match between Pizzo Mondello and the Newark-Hartford APTS (Hüsing et al., 2011) was found to be consistent with the long-Norian magnetostratigraphic correlation scheme proposed by Muttoni et al. (2004a) (Fig. 11).

Running in parallel with debate about the length of the Norian have been questions about the duration of the Rhaetian, from approximately 


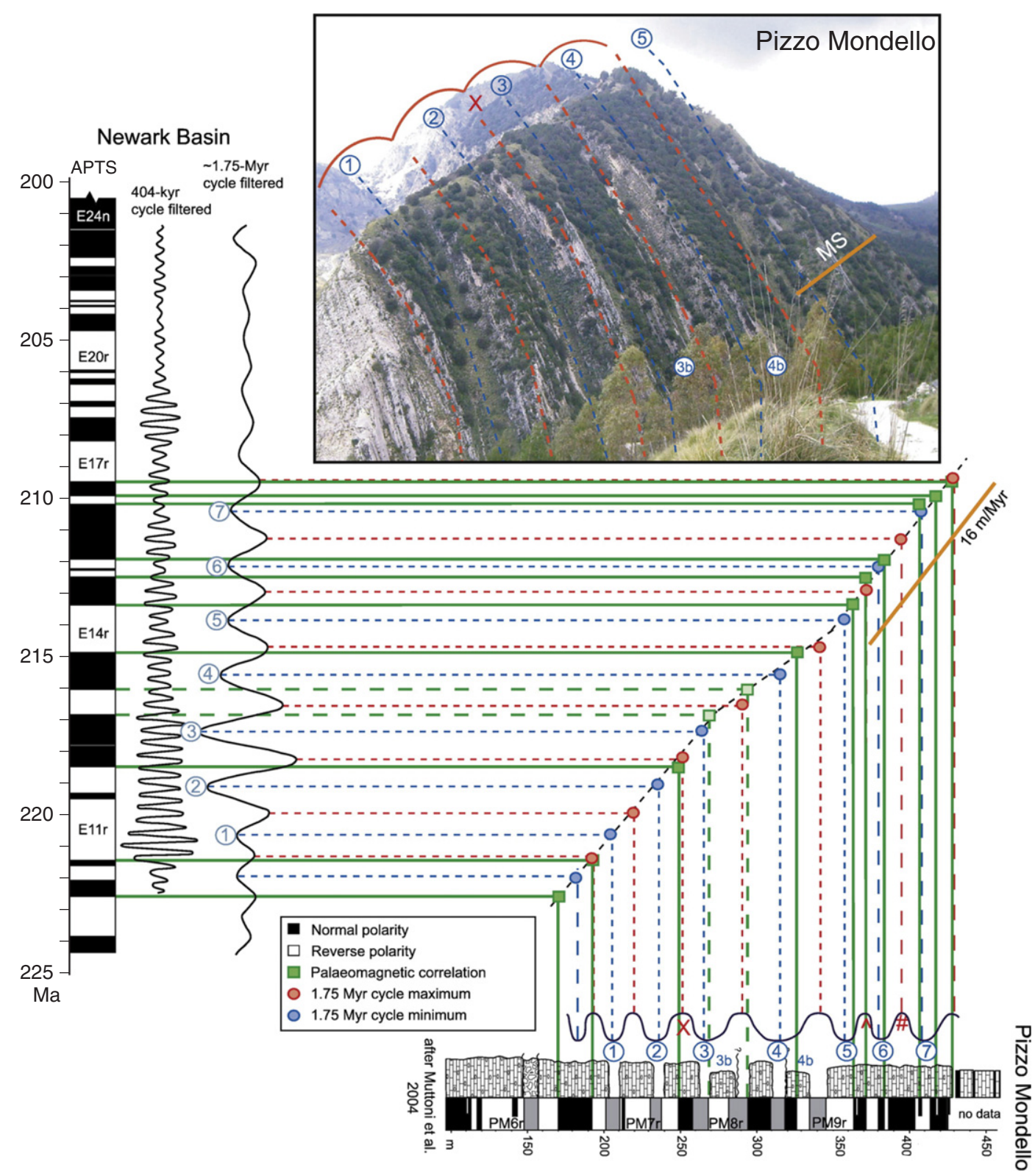

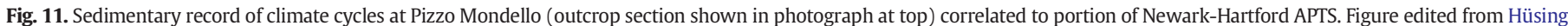
et al. (2011).

2 Myr (Callegaro et al., 2012; Gallet et al., 2007) to something more like $9 \mathrm{Myr}$ (Muttoni et al., 2010). This wide disparity in large part was (and continues to be) due to varying biostratigraphic criteria for recognition of the Norian/Rhaetian boundary. Correlation of the magnetobiostratigraphy of the Global Stratotype Section and Point (GSSP) candidate for the base of the Rhaetian at Steinbergkogel (Austria) to Chron E16r of the Newark APTS (Hüsing et al., 2011) suggested an age close to 209.5 Ma (Fig. 12). This was consistent with the long Rhaetian option and adopted, for example, in the Geological Time Scale 2012 (Gradstein et al., 2012) although the date is shown as 208.5 Ma in a more recent (v. 2016/12) IUGS/ISC chronostratigraphic chart (www.stratigraphy.org). Because of taxonomic issues regarding the nominate conodont species (Misikella posthernsteini), whose first appearance datum is supposed to coincide with the base of the Rhaetian, Maron et al. (2015) proposed using an alternative chemostratigraphic criterion (negative shift of ca. $6 \%$ of the $\delta^{13} \mathrm{C}_{\text {org }}$ occurring $50 \mathrm{~cm}$ below the first appearance of $M$. posthernsteini sensu stricto) in the GSSP candidate at Pignola-Abriola (Italy) that can be magnetostratigraphically correlated to Chron E20r.2r at 205.7 Ma. This alternative criterion for the base of the Rhaetian, which has been proposed as the basis of the Norian/Rhaetian boundary GSSP at the Pignola-Abriola section (Bertinelli et al., 2016), is important to bear in mind for interpreting biostratigraphically-calibrated U-Pb dates discussed below.

Better defined are the marine-terrestrial correlations for the Hettangian and the Hettangian/Sinemurian boundary because the GSSP and criteria for definition have been already agreed upon (Bloos and Page, 2002). The magnetic polarity pattern is rather simple in the Hartford section: a 1.6 Myr-long normal polarity Chron $\mathrm{H} 24 \mathrm{n}$ ( $=\mathrm{E} 24 \mathrm{n}$ ) encompassing the CAMP interbedded basalts and a million years of subsequent sediment deposition is followed by three relatively short reverse polarity interval (H25r, H26r and H27r) (Kent and Olsen, 2008) (Fig. 3). An independent astronomically-calibrated magnetobiostratigraphy for Hettangian and Sinemurian marine sections at St. Audrie's Bay and East Quantoxhead in Somerset, United Kingdom (Hüsing et al., 2014) agrees remarkably well with the Hartford 


\section{Newark-Hartford APTS}

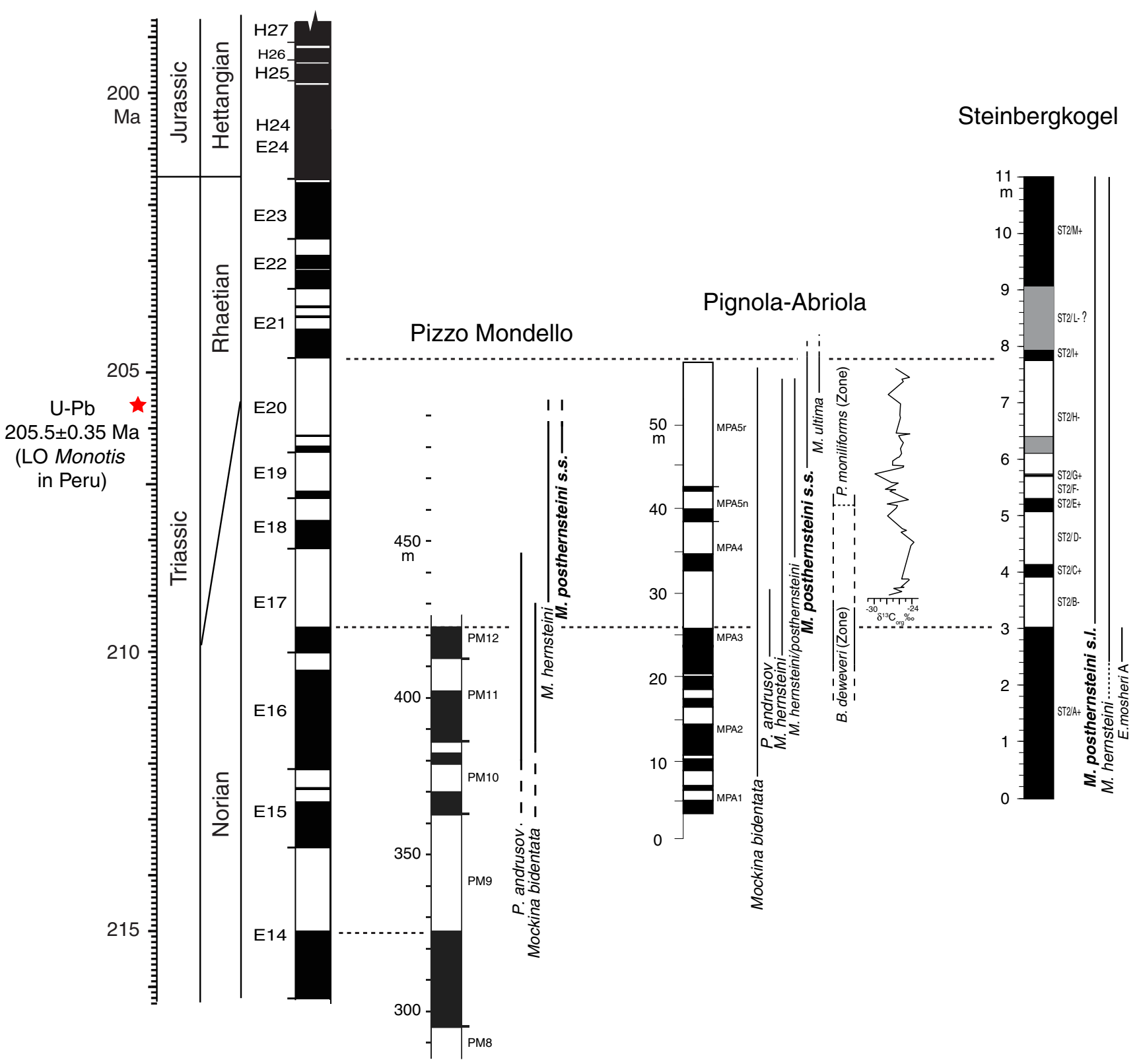

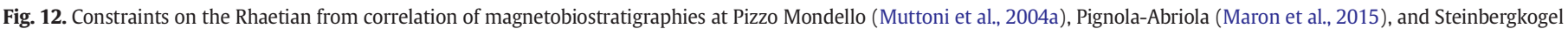
(Hüsing et al., 2011) to the Newark-Hartford APTS. Figure adapted from Maron et al. (2015).

terrestrial record at better than the 405-kyr long eccentricity level (Fig. 13). Moreover, the St. Audrie's Bay-East Quantoxhead magnetobiostratigraphic record encompasses the GSSP for the Hettangian-Sinemurian boundary (Bloos and Page, 2002), which falls close to magnetozone AQ2r, correlative to Chron H25r (Hüsing et al., 2014).

\section{Comparison of Newark-Hartford APTS with other U-Pb dates}

The 32.5 Myr-long Newark-Hartford APTS is fundamentally a time series of orbitally-forced climatic effects that are assumed to be both accurately recorded and recognized in the geological record. This floating astrochronology is anchored only at one level, near the younger end of the sequence by U-Pb zircon dates for the onset of CAMP volcanics just after Chron E23r. This simple scheme makes the Newark-Hartford APTS amenable to verification by independent high-precision U-Pb dates. Correlations to the Newark-Hartford APTS also make testable predictions about the relative durations of geologic stages. The challenge has been to find dated levels that can be precisely correlated to the Newark-Hartford APTS.

\subsection{Carnian/Norian boundary}

A U-Pb zircon date of $237.77 \pm 0.14$ Ma for an ash layer in the last ammonoid subzone of the Ladinian Stage (regoledanus) from the Rio Nigra section close to the Ladinian-Carnian GSSP at Stuores (Mietto et al., 2012) points to an age of nearly 237 Ma for the base of the Carnian (Fig. 14; ; see also paragraph 5.2). Three marine hosted U-Pb zircon dates of middle to early Norian age according to conodonts are $223.8 \pm 0.74$ and $224.47 \pm 0.29$ Ma from British Columbia (Daikow et al., 2011; Diakow et al., 2012), and $225 \pm 3$ Ma from Alaska (Gehrels et al., 1987). The two dates from British Columbia, although 


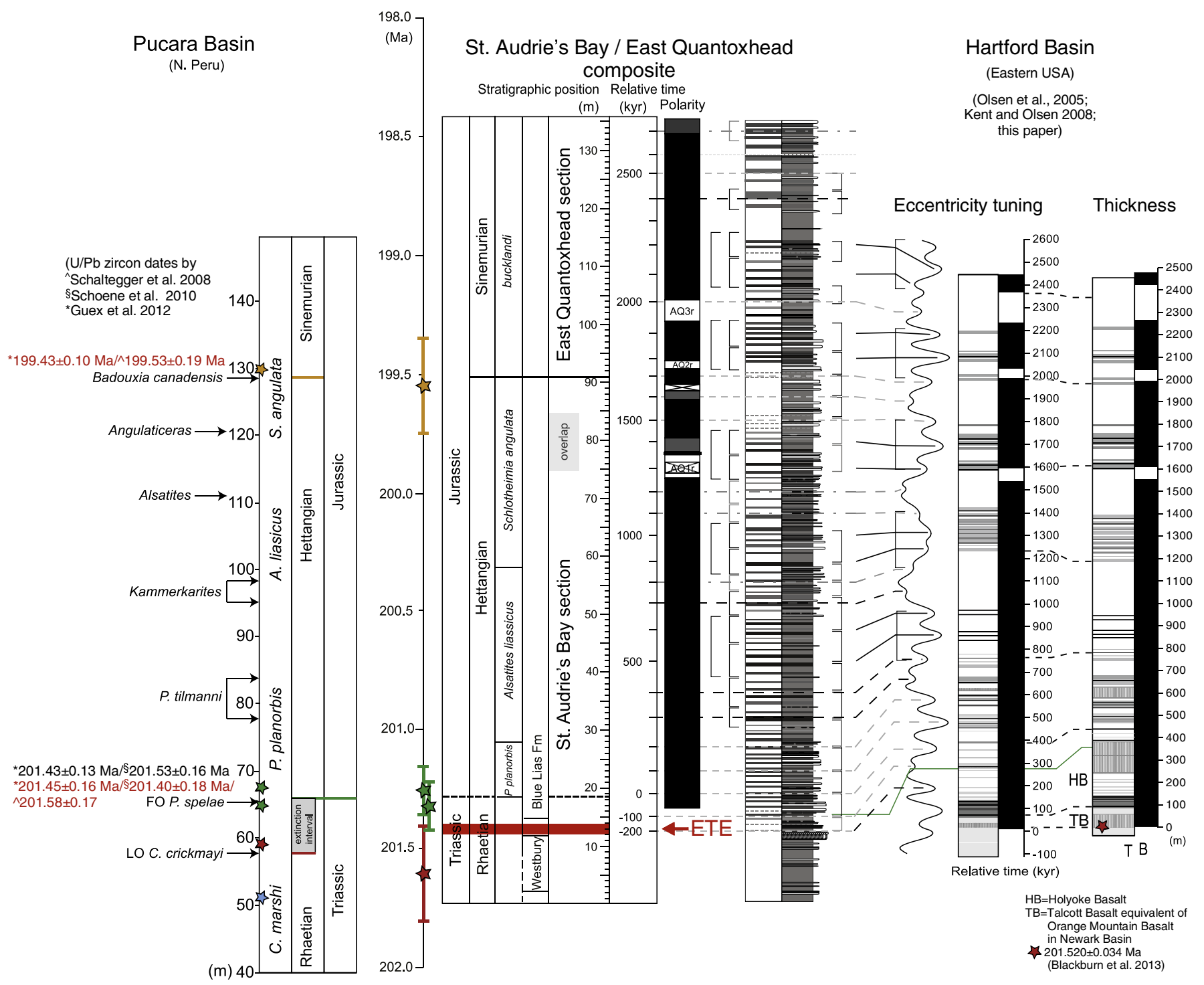

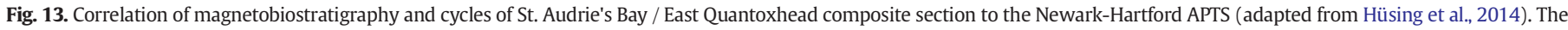

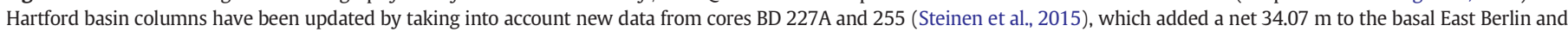
overlying section but with no change to the astrochronological ages of member boundaries (see Fig. 3 and Table 2).

yet only published in abstract, are independent and agree with the date albeit of low precision from Alaska. According to these dates, together with a late Carnian (late Tuvalian, based on conodonts) U-Pb zircon date of $230.91 \pm 0.33$ from marine strata of the Pignola 2 section in Italy (Furin et al., 2006), the Carnian/Norian boundary is constrained to be between 225 and $231 \mathrm{Ma}$. These data alone are compatible with only the long Norian option.

The older end of the Newark-Hartford APTS is based on extrapolation of sediment accumulation rates in the Raven Rock members of the Stockton Formation back from around 226 Ma to $233 \mathrm{Ma}$ (Fig. 9). The magnetostratigraphic correlations of the Silicka Brezova (Channell et al., 2003) and Pizzo Mondello (Muttoni et al., 2004a) Tethyan marine sections to the Newark basin APTS suggest the Carnian/ Norian boundary should be broadly within Chron E7r at about $227 \mathrm{Ma}$ (Fig. 10). Correlation of the U-Pb zircon dated, conodontbearing Pignola 2 section from Italy to the Newark-Hartford APTS provides independent insights on the age of the base of the Newark basin APTS (Furin et al., 2006). According to Furin et al. (2006), the biostratigraphic correlation using conodonts between Pignola 2 and Pizzo Mondello indicates that the 5-cm-thick Aglianico volcanic ash bed with a U-Pb zircon date of $230.91 \pm 0.33$ Ma should fall in the lowermost part of the Pizzo Mondello section and within Chron E6 of the Newark-Hartford APTS at around $229 \mathrm{Ma}$. The conodont biostratigraphy of Pignola 2 has been however recently revised (Rigo et al., 2012). So was the biostratigraphy of Pizzo Mondello (Mazza and Rigo, 2012), a revision resulting in a more expanded Carnian assemblage and a confirmation of the position of the Carnian/Norian boundary within PM4r (as approximated for example by conodonts Metapolygnathus communisti or M. parvus) correlative to Chron E7r in the Newark APTS as originally suggested by Muttoni et al. (2004a). A selection of revised Carnian conodonts from both sections, including M. praecommunisti, Paragondolella noah, P. oertlii, and Carnepigondolella carpathica, has been used to erect an informal concomitant range zone that seems to indicate that the base of Pizzo Mondello should not extend below about the $15 \mathrm{~m}$ level at Pignola 2 and as a consequence the dated ash bed should actually fall below the base of Pizzo Mondello. This level projected on the Newark-Hartford APTS following the Pizzo Mondello to Newark correlation of Muttoni et al. (2004a) and this study for magnetozones older than PM4r falls broadly within Chrons E5-E4 at around 231 Ma (Fig. 14). This is in substantial agreement with - and thus serves to confirm the -(extrapolated) astrochronological ages of the Newark-Hartford APTS. 


\subsection{Norian/Rhaetian boundary}

More complicated is the interpretation of U-Pb dates for the Norian/ Rhaetian boundary and the resulting duration of the Rhaetian (Fig. 15). A long (6-9 Myr) Rhaetian option was favored from the frequency of polarity reversals as well as their correlation to the Newark-Hartford APTS of a 500 m-thick composite section of Rhaetian strata in the Southern Alps (Muttoni et al., 2010). Despite the prevalence of hardgrounds (hiatuses) in the slowly accumulating Halstatt facies, detailed sampling of the nominal $10 \mathrm{~m}$-thick proposed Rhaetian GSSP section at Steinbergkogel in Austria also showed a sufficiently large number of polarity reversals to favor a relatively long (of order $10 \mathrm{Myr}$ ) Rhaetian (Hüsing et al., 2011). In contrast, the nominally 20 m-thick section at Oyuklu in Turkey showed only a few polarity changes and this helped inspire the concept of a short (only about 2 Myr) Rhaetian (Gallet et al., 2007).

$\mathrm{U}-\mathrm{Pb}$ zircon dates from volcanic ash layers within strata recording the last occurrence of large monotid bivalves in the Pucara Basin in Peru suggest an age between $205.70 \pm 0.15 \mathrm{Ma}$ and 205.30 $\pm 0.14 \mathrm{Ma}$ for the Norian/Rhaetian boundary (Wotzlaw et al., 2014). This age estimate is seriously at odds with the age of around 209.5 Ma obtained by correlation of the magnetostratigraphy of the candidate Rhaetian GSSP at Steinbergkogel to the Newark-Hartford APTS (Hüsing et al., 2011). However, an alternative chemostratigraphic criterion for the base of the Rhaetian at the Pignola-Abriola candidate GSSP shows that the Norian/Rhaetian boundary can be correlated to Chron E20r.2r at 205.7 Ma (Maron et al., 2015) (Fig. 15). This age is coherent with the U-Pb zircon dates from Peru (Wotzlaw et al., 2014) and together support a modest duration of about $4 \mathrm{Myr}$ for the Rhaetian. But rather than implying a long cryptic hiatus in the Newark section, whereby the Rhaetian as traditionally (yet variously) defined is supposed to be largely missing in the Newark basin section, the mutually consistent results of Wotzlaw et al. (2014) and (Maron et al., 2015) simply mean that the palynofloral zones in the Newark Supergroup, for want of better criteria at the time for correlations with marine sections (Cornet, 1993; Cornet and Olsen, 1985), do not coincide with standard geologic stages based on marine biostratigraphy.

\subsection{Triassic/Jurassic and Hettangian/Sinemurian boundaries}

Assessments of the ages of the Triassic/Jurassic and Hettangian/ Sinemurian boundaries also come from U-Pb zircon dates on volcanic ash layers in fossiliferous marine sections of the Pucara Basin in Peru (Fig. 13). Dates that bracket the first occurrence of Psiloceras spelae, the nominate datum for the base of the Jurassic at the GSSP at Kujhoch, Austria (Hillebrandt et al., 2013), indicate an age of 201.31 $\pm 0.18 \mathrm{Ma}$ for the TJB (Schoene et al., 2010), with supportive U-Pb zircon dates in the context of a detailed ammonite biostratigraphy (Guex et al., 2012). The age for the TJB from Peru is in good agreement with or perhaps slightly younger than the oldest CAMP U-Pb dates, such as the Palisade Sill/Orange Mountain Basalt (201.520 $\pm 0.034 \mathrm{Ma}$ ) and North Mountain Basalt (201.566 $\pm 0.031 \mathrm{Ma}$ ) (Blackburn et al., 2013). This would imply that the TJB post-dated the inception of CAMP activity. On the other hand, the ETE seems to just precede or is nearly coincident with the onset CAMP activity in North America and Morocco (Blackburn et al., 2013). Based on projection from the St. Audrie's Bay section (first occurrence of Psiloceras planorbis - assumed to be close to that of P. spelae), the TJB should be at $201.42 \pm 0.02$ in the Newark-Hartford APTS (Sha et al., 2015). This is within error of the $201.36 \pm 0.14$ Ma average of the bracketing dates from Peru (Wotzlaw et al., 2014; Sha et al., 2015).

A U-Pb zircon date of $199.53 \pm 0.19$ Ma from a tuff within the Badouxia canadensis beds that should closely approximate the Hettangian/Sinemurian boundary indicates, in concert with the U-Pb zircon dates also from Peru for the TJB, that the Hettangian is only about 2 Myr long (Schaltegger et al., 2008). This is in excellent agreement with the duration of the Hettangian determined by astrochronology in the St. Audrie's Bay-East Quantoxhead composite section (Fig. 13) and is fully consistent with the Newark-Hartford APTS (Hüsing et al., 2014).

\section{Extension of the Newark-Hartford APTS into younger and older strata}

\subsection{Sinemurian and younger}

There is another $2000 \mathrm{~m}$ of section above the sampled interval of the Portland Formation in the Hartford basin. Cyclicity, however, is less apparent and the lithology becomes dominated by more eolian facies (Hubert et al., 1992), making it difficult to map distinctive units, establish accurate stratigraphic placement of sampling sites, as well as to find suitable lithologies there to extend the magnetostratigraphy upward into and above Chron H27n. The marine sections at St. Audrie's BayEast Quantoxhead (Britain) offer better prospects for extending the polarity sequence into Sinemurian and younger strata as well as for a bridge to Sinemurian and Pliensbachian (to about $183 \mathrm{Ma}$ ) magnetostratigraphies from the Umbrian Apennines (Fonte Avellana and Cingoli; Channell et al., 1984) and the southern Italian Alps (Colle di Sogno; Channell et al., 2010), even though radiometrically dated levels or cycle stratigraphic age controls are apparently not yet available. In any case, there is still a sizable age gap to link these magnetostratigraphic records to the Late Jurassic-Early Cretaceous oceanic anomaly M-sequence, which is relatively secure back to Chron M29 or about 155 Ma (Malinverno et al., 2012; Tominaga and Sager, 2010) and verified by magnetostratigraphy (Channell et al., 1995, 2010; Speranza et al., 2005). However, even the basic polarity sequence is far less certain in the Middle Jurassic where the oceanic record is characterized by small-scale magnetic anomalies of continued decreasing amplitude (Cande et al., 1978) that are now numbered back to M44 with an extrapolated age of about 170 Ma (Sager et al., 1998; Tominaga et al., 2008) but of uncertain origin (Gee and Kent, 2007; McElhinny and Larson, 2003). The available Middle Jurassic magnetostratigraphic records tend to be very noisy with many apparent flips in polarity, making correlations uncertain (e.g., Steiner et al., 1987).

\subsection{Carnian and older}

Stratigraphic sections with age control older than the base of the Newark-Hartford APTS (extrapolated age of about 232.5 Ma) within the Carnian are Mayerling in Austria (Gallet et al., 1998) and the GSSP for the Ladinian/Carnian boundary at Stuores in Italy placed at the regoledanus/canadensis ammonoid subzone boundary (Mietto et al., 2012). The Stuores GSSP has been tentatively correlated to the nearby Rio Nigra section that provided a U-Pb zircon date of $237.77 \pm$ 0.14 Ma for an ash layer located in the regoledanus subzone just above the neumayri/regoledanus subzone boundary, approximately one ammonoid subzone below the Ladinian/Carnian (regoledanus/ canadensis) boundary estimated at about $237 \mathrm{Ma}$ (Mietto et al. (2012) and references therein) (Fig. 14). These and several other Middleearly Late Triassic sections including the Seceda core (Muttoni et al., 2004b) were used to erect a radiometrically constrained (U-Pb zircon dated) magnetobiostratigraphy extending from the late Anisian into the Carnian (see Fig. 5 in Hounslow and Muttoni (2010) and references therein), with the Anisian/Ladinian boundary presently estimated at 242 Ma (Mundil et al., 2010). A U-Pb zircon date of 238.0 $(+0.4 /-0.7)$ Ma from an ash bed within the Ladinian archelaus ammonoid zone (whose upper part corresponds to the neumayri subzone) at Seceda, considered a minimum age because potentially affected by $\mathrm{Pb}$ loss (Mundil et al., 2010), when projected onto Mayerling using the correlations scheme of Hounslow and Muttoni (2010) provides additional support for a Ladinian/Carnian boundary age at close to $237 \mathrm{Ma}$ (Mietto et al., 2012). 
The gap between Stuores-Mayerling and the Carnian-Norian record at Pizzo Mondello (see also above) is partially bridged by a cycle-calibrated magnetostratigraphy of Carnian carbonates from South China (Minzoni et al., 2015; Zhang et al., 2015) (Fig. 14). The 210-m-thick Wayao composite magnetostratigraphy encompassing the Zhuganpo and Xiaowa formations has been astrochronologically calibrated using long and short eccentricity resulting in a floating magnetochronology spanning about 2.4 Myr (Zhang et al., 2015). It is not obvious how to insert this floating chronology into our Carnian correlation framework because the biostratigraphic age constraints of the

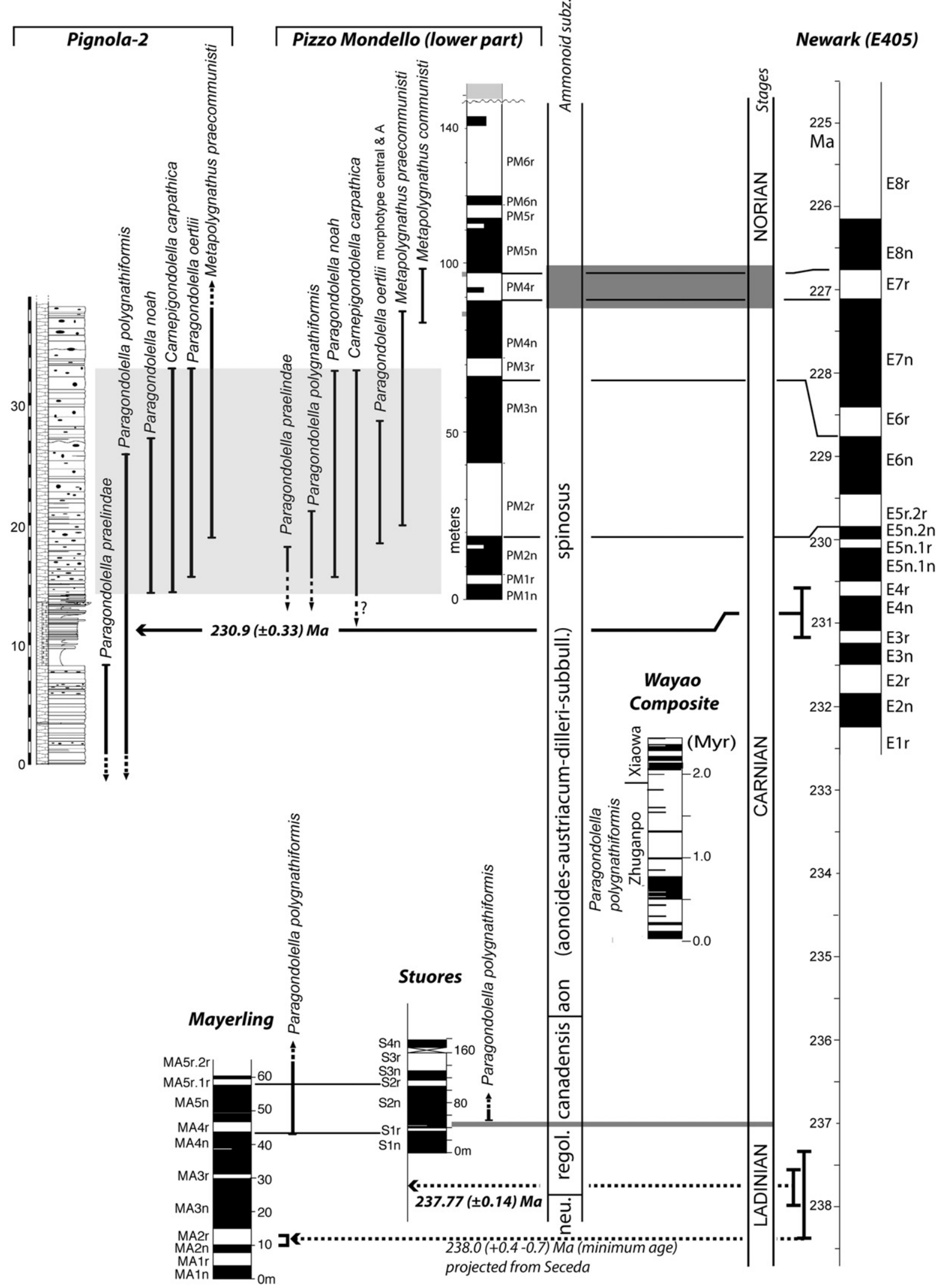


investigated units are very sparse. The Zhuganpo Formation is considered Carnian in age based essentially on the presence of conodont Metapolygnathus (Paragondolella) polygnathiformis (Zhang et al., 2015), which first appears at Stuores close to the base Carnian level and is last present at Pignola 2 and Pizzo Mondello in levels below the base of the Norian. According to these data, we tentatively consider the 1.3 Myr-long reverse polarity interval encompassing the upper Zhuganpo and the lower Xiaowa formations (Zhang et al., 2015) as a potential extension within the Carnian of Chron E1r.

\section{The 'missing' Rhaetian}

A persistent refrain in the literature is that most of the Rhaetian is missing in the Newark Supergroup. For example, an unconformity is placed by Kozur and Weems (2010) within a few decimeters to decameters below the CAMP volcanics practically wherever they occur (Culpeper, Gettysburg, Newark, Hartford and Fundy basins, their Figs. 9 \& 10 ) on the basis of conchostracan biostratigraphy. Tanner and Lucas (2015) assert that correlation of "pollen and conchostracan zones between the Newark Supergroup and the Germanic Triassic, indicates that most of Rhaetian and a portion of late Norian time is not represented by sediment in the Newark basin and elsewhere in the Newark Supergroup." Van Veen (1995) argues that the reported palynofloral change just below the North Mountain Basalt and shortly before the end-Triassic extinction in the Fundy basin (Fowell and Olsen, 1993) actually took place 2-3 Myr earlier based on evidence from Western Europe, a viewpoint that was shared at the time by Kuerschner et al. (2007) from work on the Tiefengraben section in Austria. Finally, Gallet et al. (2007) suggest that the Rhaetian is at least partly missing in the Newark basin based on magnetostratigraphic correlations with a condensed marine section in Turkey (Oyuklu).

The purported hiatus in the Newark section is often intermingled with the so-called short-Rhaetian option (Ogg, 2012). When the temporal extent of the hiatus according to various workers is shown explicitly, as by Wotzlaw et al. (2014), it is placed below the CAMP lavas, squeezed into the lowest part of Chron E24n and just above Chron E23r (Fig. 15). The hiatus effectively is made to coincide with the ETE. In fact, Tanner and Lucas (2015) reassign Chron E23r from the late Rhaetian to the late Norian on the basis of the conchostracan Shipingia olseni immediately below and with the late Norian palynomorphs (e.g. Patinasporites densus) above this magnetozone. However, the recorded presence of the very short (nominally $10 \mathrm{kyr}$ ) Chron E23r immediately below CAMP basalts in three entirely separate basins, namely Newark (Kent and Olsen, 1999; Kent et al., 1995; Olsen et al., 1996a), Fundy (Deenen et al., 2011) and Argana (Deenen et al., 2010) (see Fig. 8), makes such a major regional unconformity untenable. This is because the unconformity would require essentially identical intervals of nondeposition and/ or erosion in all of these basins, so that somehow deposition halted immediately after or else each section was eroded to variable depths exactly down to just above Chron E23r, the shortest identified chron in the Newark-Hartford APTS. But not to be deterred, Tanner and Lucas (2015) do not regard such an argument as precluding a regional unconformity and speculate that a late Rhaetian episode of uplift along the entire rift axis might somehow have caused such precisely timed nondeposition or erosion of the exposed strata in all of the rift valleys prior to the flood basalt eruptions.

Specific evidence contradicting the notion that Rhaetian time is somehow missing in the Newark Supergroup comes from the magnetobiostratigraphy of the St. Audrie's Bay section in Britain (Briden and Daniels, 1999; Hounslow et al., 2004) (Fig. 16). The St. Audrie's Bay measured section is about $125 \mathrm{~m}$ thick and comprised of the Mercia Mudstone, Penarth and Lias Groups. The exposed Mercia Mudstone consists of around $100 \mathrm{~m}$ of reddish to grey dolomitic mudstones, siltstones and evaporites of floodplain and playa lake origin. The overlying Penarth Group, all of 13 m-thick, is divided into the Westbury Formation and overlying Lilstock Formation, which is further divided into the Cotham and overlying Langport members. The Westbury Formation and up into the lowermost Cotham Member of the overlying Lilstock Formation is reported to contain Rhaetavicula contorta (Golebiowski, 1990; Hounslow et al., 2004), a fossil bivalve that is known from the shallow-water facies of the Kössen Formation of the Rhaetian type area (Golebiowski, 1990; Kozur, 2003). Just above in the middle of the Cotham Member there is a prominent horizon of distinctly disturbed sediment capped by what could be taken as a bedding exposure surface with deep desiccation cracks and local evidence of erosion (Hesselbo et al., 2002; Hounslow et al., 2004; Mayall, 1983). The Cotham and the overlying Langport members do contain some marine fossils, notably conodonts (e.g., Chirodella verecunda) that occur just below the top of the Langport Member at Lilstock (Swift and Martill, 1999). These conodonts occur in association with Misikella conformis and $M$. posthernsteini in the Langport Member and the immediately overlying pre-planorbis beds, respectively, and are indicators of a Rhaetian age (Hounslow et al., 2004). The Lias Group consists of limestones and shales with the diagnostic Early Jurassic ammonoid (P. planorbis) just above the pre-planorbis beds (PPB in Fig. 16) of the Blue Lias Formation at the top of the magnetostratigraphic section.

Within these broad biostratigraphic constraints, for example, that the ETE and TJB must occur somewhere between the top of the Lilstock Member and the base of the P. planorbis subzone of the Blue Lias Formation (i.e., presumably within the pre-planorbis beds), a satisfactory correlation can be made of the St. Audrie's magnetostratigraphy to the NewarkHartford APTS, especially for the Mercia Mudstone Group initially studied by Briden and Daniels (1999) and sampled further by Hounslow et al. (2004). According to these studies, the Mercia magnetostratigraphy can be convincingly correlated from Chron E14r at the exposed base of the section up into Chron E20n at the top of the unit, with the 30 m-thick interval of predominantly reverse polarity encompassing the Blue Anchor Formation diagnostically corresponding to predominantly reverse polarity Chrons E19 and E20 (Fig. 16). The sediment accumulation rate for the Mercia Mudstone would be about $10 \mathrm{~m} / \mathrm{Myr}$ (100 m from 214.5-204.5 Ma). Correlation of the Penarth magnetostratigraphy is much more ambiguous but from the foregoing should correspond to most of Chrons E21 to E23. This would imply a low net sediment accumulation rate of only around $4 \mathrm{~m} / \mathrm{Myr}$ ( $13 \mathrm{~m}$ of section from 204.5-201.5 Ma). Characterizing a polarity pattern in such a low sedimentation rate section is difficult in the face of sampling limitations and smearing from processes like bioturbation and haloturbation. Uncertainties in correlating the resulting polarity sequence are compounded if

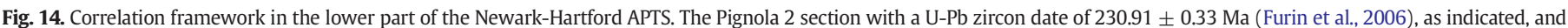

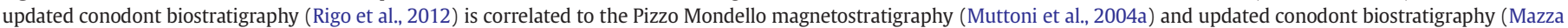

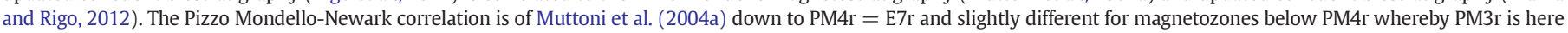

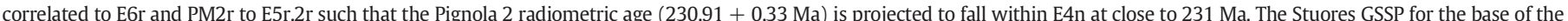

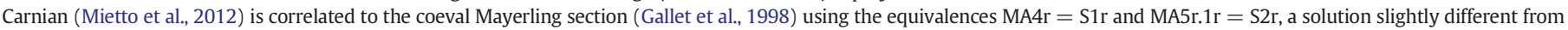

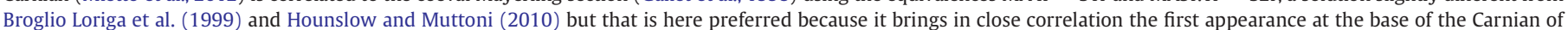

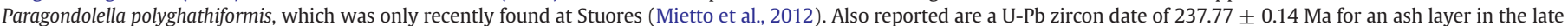

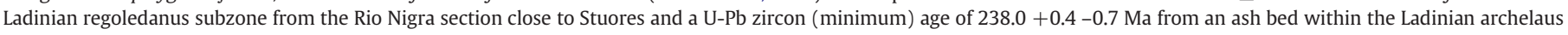

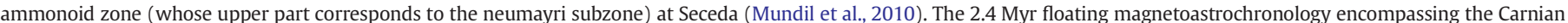

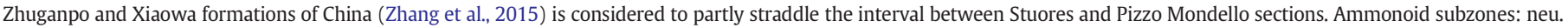

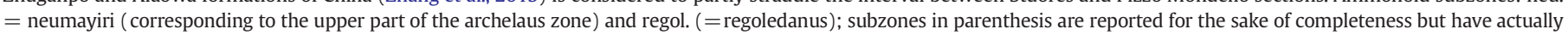
not been found in any of the considered sections. 


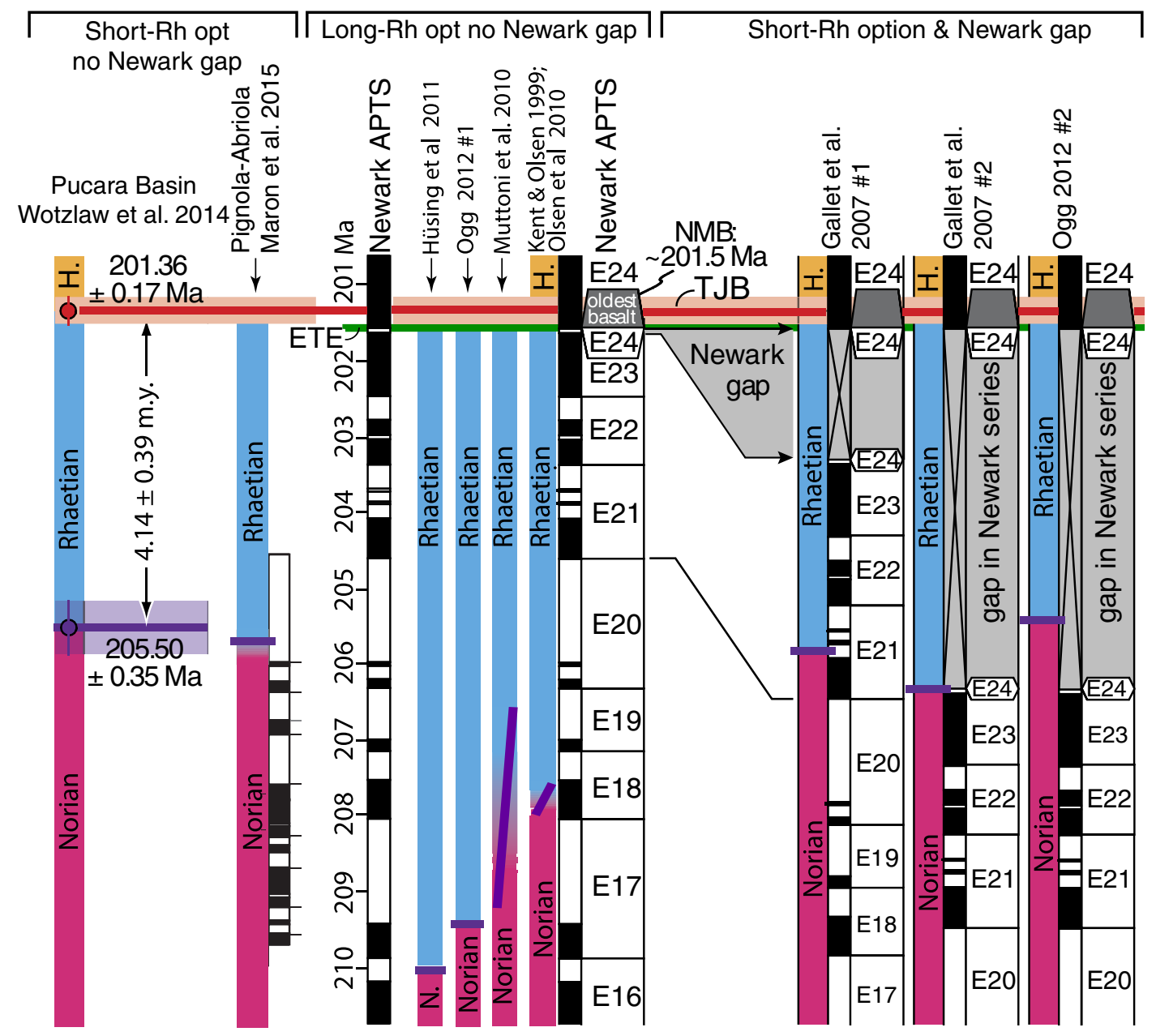

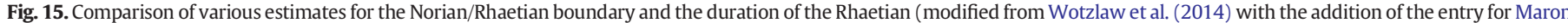

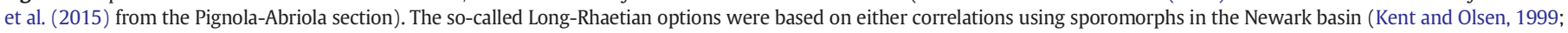

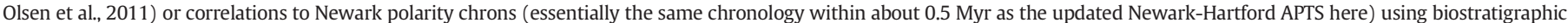

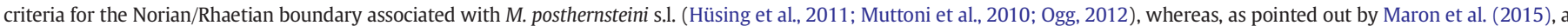

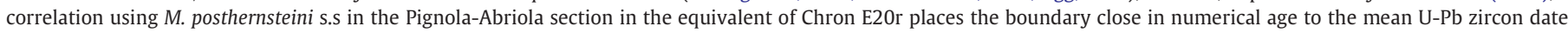

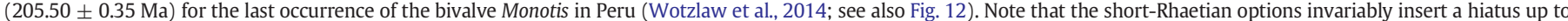

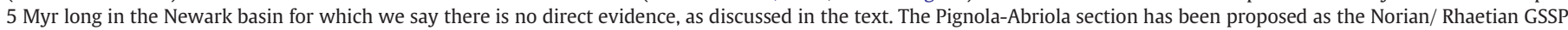
(Bertinelli et al., 2016). See also Golding et al. (2016) for U-Pb zircon geochronology on Rhaetian sections in British Columbia.

the Penarth is also condensed because of hiatuses, such as the mudcrack level within the Cotham Member suggests are present. Importantly, none of the reverse polarity magnetozones in the Westbury Formation are likely to represent Chron E23r, which is only about $10 \mathrm{kyr}$ long according to cycle stratigraphy and thus highly unlikely to be recovered by spot sampling of a section that accumulated at only $0.4 \mathrm{~cm} / \mathrm{kyr}$. A similar argument applies to reverse magnetozone SA5r in the lowest Blue Lias Formation, whose origin and significance are enigmatic. Nonetheless, the overall magnetostratigraphic correlation of the St. Audrie's Bay section to the Newark-Hartford APTS is sufficient to establish that the interval in the upper Passaic Formation from Chrons E21 to E23 is most probably Rhaetian in age, corresponding to the reported range of $R$. contorta in the Penarth Group.

Lastly, from a purely operative standpoint, if 3 Myr or more of Late Triassic time were not recorded in the Newark basin as supposed by some authors, this would have comparable consequences in the timing of events based on anchoring the astrochronology below the alleged unconformity to the $\mathrm{U}-\mathrm{Pb}$ dated CAMP lavas above it. There is no evidence of such offsets. In fact, the excellent agreement of the U-Pb zircon date of $230.91 \pm 0.33 \mathrm{Ma}$ in marine strata of late Carnian age (Furin et al., 2006) correlated to Chrons E4 with a Newark-Hartford APTS age in the range of 230.5-231 Ma would preclude a significant hiatus, as would the agreement with available $\mathrm{U}-\mathrm{Pb}$ zircon dates for constraints on the ages for the Carnian/Norian and Norian/Rhaetian boundaries correlated to the Newark-Hartford APTS. More generally, the 70 Myr-long TriassicJurassic Inuyama-ATS chert sequence in Japan shows a $1.8 \mathrm{Myr}$ supercycle (Ikeda and Tada, 2014) suggesting that the NewarkHartford sequence, where the $1.8 \mathrm{Myr}$ supercycle was first found (Olsen and Kent, 1999), is most probably complete.

\section{7. $\mathrm{pCO}_{2}$ estimates from paleosols and the $\delta^{13} \mathrm{C}$ record from marine carbonates}

Global climate change is always difficult to gauge. The Triassic practically stands alone as a period in the Phanerozoic with no evidence of persistent polar ice sheets (Frakes and Francis, 1988) and corresponds to an oscillation towards relatively warm tropical sea surface temperatures based on oxygen isotopes in calcite and aragonite shells (Veizer et al., 2000). Varying concentrations of atmospheric $p \mathrm{CO}_{2}$ would be expected to exert a global climate signal and influence sea-surface temperatures but the role of $\mathrm{CO}_{2}$ in climate models (Berner, 2006) is highly dependent on very few and often highly scattered estimates especially for pre-Cenozoic time (Royer, 2006). 


\section{Newark-Hartford APTS}

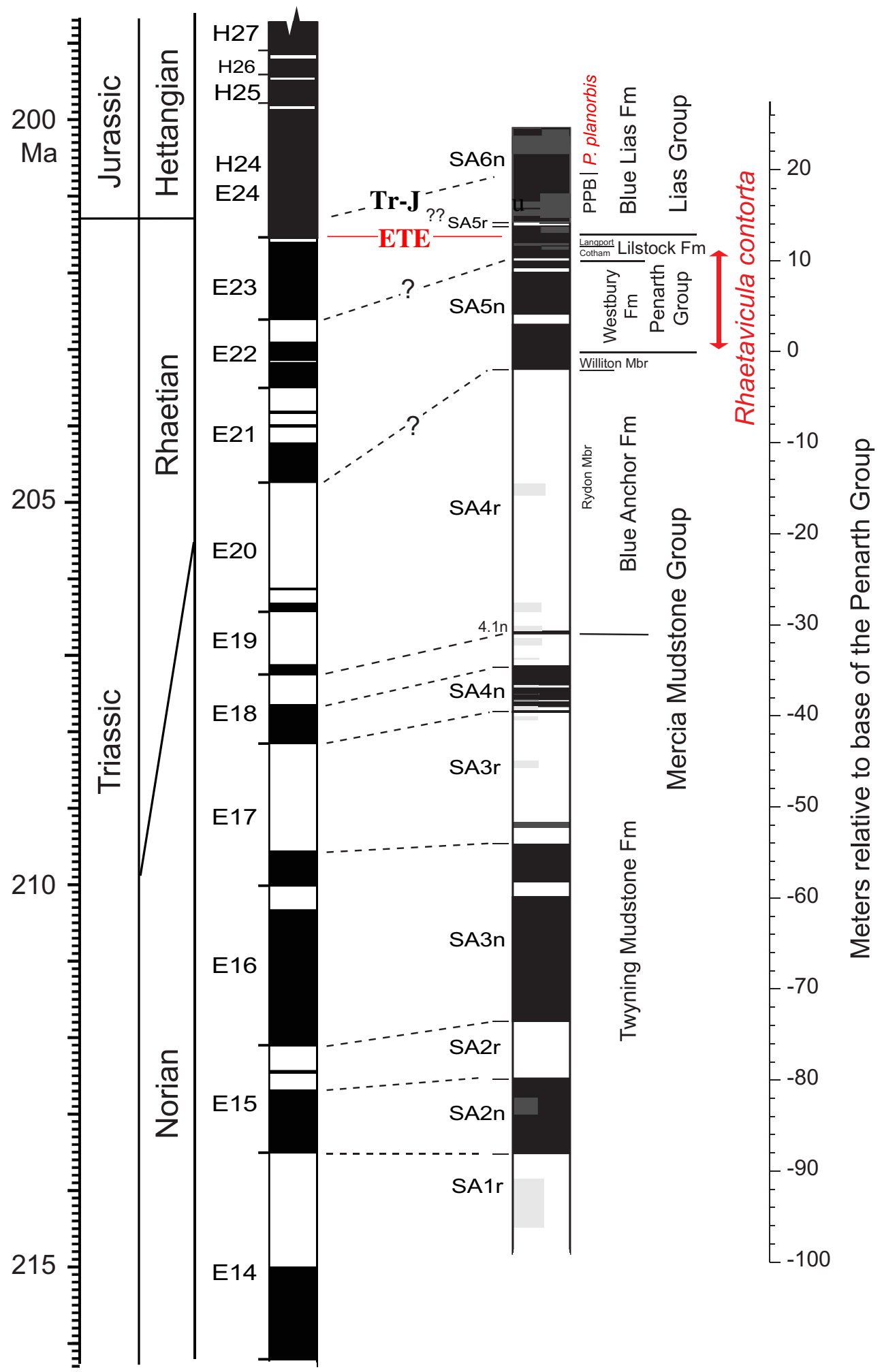

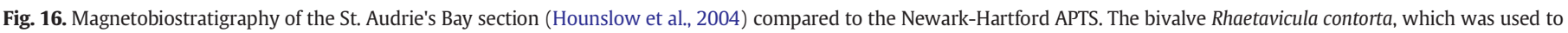

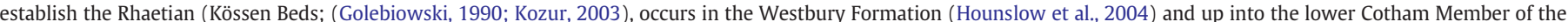

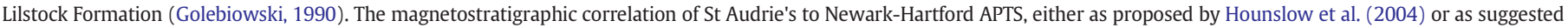

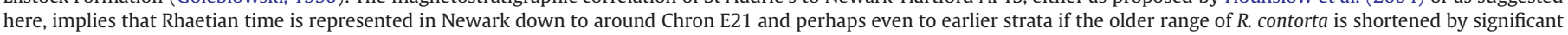
hiatus(es) at around the base of the Penarth Group. 
Paleosol carbonates can provide an excellent proxy of $\mathrm{pCO}_{2}$ (Cerling, 1999). Paleosols are found throughout much of the Newark-Hartford cyclical facies, allowing tests of repeatability by correlation of specific Van Houten cycles within a basin and a detailed chronology by direct registry to the Newark-Hartford APTS. Estimates of $p \mathrm{CO}_{2}$ were obtained from carbon isotope analyses of paleosol carbonates in sedimentary units interbedded with CAMP lavas to determine their outgassing potential (Schaller et al., 2011a, 2011b, 2012) and in survey mode over the entire Newark-Hartford record to establish long-term trends (Schaller et al., 2015) (Fig. 17). The results show increases in $p \mathrm{CO}_{2}$ values by roughly a factor of two immediately after each CAMP lava unit and their subsequent decay over each ensuing 100-200 kyr interval based on the astrochronology. This provides experimental confirmation for models of the impact of a large igneous province on $\mathrm{CO}_{2}$ outgassing and consumption by chemical weathering (Dessert et al., 2001). The long-term trends show high and steady $p \mathrm{CO}_{2}$ values in the early to middle Norian (230-215 Ma), a dip to a low at $212 \mathrm{Ma}$ and a rise back to earlier steady values by $210 \mathrm{Ma}$, followed by a steady decrease to just before CAMP eruptions. The overall pattern of atmospheric $p \mathrm{CO}_{2} \mathrm{con}-$ centrations broadly agrees with model results based on increasing $\mathrm{CO}_{2}$ consumption by weathering as more continental area was exposed to warm and humid equatorial climate during northward drift of Pangea (Goddéris et al., 2008; Schaller et al., 2015) but disagrees with the GEOCARBSULF carbon cycling model, which predicts steady $p \mathrm{CO}_{2}$ values over the Late Triassic (Berner, 2006).

Variations in $\delta^{13} \mathrm{C}$ of marine carbonates basically reflect the relative burial rate of inorganic carbon and fractionated organic carbon. The relative proportions are ultimately controlled by tectonics via nutrient supply through erosion and weathering, which can variably sustain productivity by formation of burial loci in sedimentary basins or by injection into the global carbon pool of light isotopic sources of crustal (e.g., clathrates), mantle (volcanic) or even extraterrestrial (cometary) sources. The $\delta^{13} \mathrm{C}$ values of marine carbonates are thought to reflect global ocean isotopic compositions and can thus be useful for correlation. A suite of $\delta^{13} \mathrm{C}$ measurements on Late (and Middle) Triassic carbonates including Pizzo Mondello, Brumano and Italcementi (Italy) that are correlated via magnetobiostratigraphy to the NewarkHartford APTS provides a new age-calibrated target curve (Muttoni et al., 2014) (Fig. 17). The target curve shows $\delta^{13} \mathrm{C}$ values of $2-3 \%$ in the Carnian punctuated by two negative excursions at around $233.5 \mathrm{Ma}$ and $230 \mathrm{Ma}$, followed by a small positive excursion at $227 \mathrm{Ma}$ across the Carnian/Norian boundary. The Norian record, mainly from Pizzo Mondello, is characterized by a long-term decreasing trend from average values of $2-3 \%$ to $1-2 \%$. This trend is punctuated by an additional negative excursion at around 217-213 Ma in the middle Norian. Finally, after a late Norian-early Rhaetian data gap, $\delta^{13} \mathrm{C}$ values in the Rhaetian are on average heavier (up to 3-4\%) but display an oscillatory behavior with large and rapid increases and decreases as observed in data from Brumano and Italcementi (Muttoni et al., 2014). Aside from the uncertain origin of these oscillations, this study provides a dated $\delta^{13} \mathrm{C}$ curve that can be useful for stratigraphic correlations and to explore possible linkages between $p \mathrm{CO}_{2}$ and ocean carbonate $\delta^{13} \mathrm{C}$ (Berner, 2006).

\section{Correlations of continental sediments and paleogeography}

Magnetic polarity and cycle stratigraphies have been especially useful tools for correlations and timing of continental successions, which typically have scant fossils of rather endemic fauna and flora. Besides the studies of the Newark and Hartford basins already described in the construction of the APTS, magnetic polarity and cycle stratigraphies have been developed from many other rift basins and allow close correlation of events. These localities include the Dan River basin of North Carolina and Virgina (Kent and Olsen, 1997; Olsen et al., 2015), the Taylorsville basin of Virginia (LeTourneau, 2003), the Jacksonwald Syncline of the Newark basin in Pennsylvania (Olsen et al., 2002a, 2002b), the Fundy basin of Nova Scotia (Deenen et al., 2011; Kent and
Olsen, 2000), the Argana basin of Morocco (Deenen et al., 2010), Jameson Land in East Greenland (Clemmensen et al., 1998; Kent and Clemmensen, 1996), the Chinle Formation of the Colorado Plateau (Donohoo-Hurley et al., 2010; Molina-Garza et al., 2003; Molina-Garza et al., 1991; Steiner and Lucas, 2000; Zeigler and Geissman, 2011; Zeigler et al., 2008), the Los Colorados Formation in the Ischigualasto-Villa Union basin in Argentina (Kent et al., 2014), the Mercia Mudstone at St. Audrie's Bay in Britain (Briden and Daniels, 1999; Hounslow et al., 2004), and the longneglected Keuper in the Germanic basin waiting to be (re)done after being the subject of a very early application of partial demagnetization techniques on the equivalent rock unit in Britain (Creer, 1959).

Paleolatitudes are typically obtained in a comprehensive magnetostratigraphic study. This information can be used to differentiate effects of global climate change (e.g., due to changes in greenhouse gases; Schaller et al., 2015) from more localized changes in environment as Pangea drifted northward across latitudinal climate belts (Kent and Tauxe, 2005). Paleogeographic reconstructions that use latitudinal data corrected for sedimentary inclination shallowing (Kent and Tauxe, 2005) are shown in (Fig. 18). It can be seen that by the end of the Triassic, the Newark basin had drifted to around $20^{\circ} \mathrm{N}$ within the tropical arid belt (e.g., eolian deposits in the Pomperaug basin in Connecticut (LeTourneau and Huber, 2006) and especially in the Fundy basin in Nova Scotia (Hubert and Mertz, 1980)) whereas some of the European basins had already progressed to $40^{\circ} \mathrm{N}$ and even higher latitudes in the temperate humid belt (e.g., fossil megafloras in Jameson Land, East Greenland and Scania, southern Sweden: McElwain et al., 1999, 2007). Kuerschner et al. (2007) had dismissed the possibility raised by Kent and Olsen (2000) that floral provincialism could account for the diachronous extinction of spore taxa. However, it seems unlikely that these disparate climatic settings in eastern North America and Greater Europe would have had many floral assemblages in common. Instead, the fossil assemblages in the different land areas may indeed be diachronous on account of the northward drift of Pangea across climate belts and provide more of an eco-stratigraphy rather than a chronostratigraphic correlation at this spatiotemporal scale.

\section{Conclusions}

- The Newark-Hartford APTS is paced by sixty-six (66) McLaughlin cycles, each representing climate forcing by the long astronomical eccentricity variation with the stable $405 \mathrm{kyr}$ period (Laskar et al., 2011), from 199.5 to $225.8 \mathrm{Ma}$ and encompassing fifty-one (51) magnetic polarity intervals (Chrons E8n to H27n). Extrapolation of sediment accumulation rates in the basal fluvial sediments (about $100 \mathrm{~m} / \mathrm{Myr}$ ) extends the sequence back an additional fifteen (15) polarity intervals (Chrons E1r to E7r) to $232.7 \mathrm{Ma}$. The lengths of the 66 polarity intervals vary from 0.011 to $1.63 \mathrm{Myr}$ with a mean duration of $0.53 \mathrm{Myr}$.

- The Newark-Hartford APTS is anchored to high-precision U-Pb zircon dating of the oldest CAMP basalts that provide an estimated age of 201.5 Ma for the base of the stratigraphically superjacent Washington Valley Member (the base of McLaughlin cycle 61) and 201.6 Ma using cycle stratigraphy for the onset of the immediately subjacent Chron E23r.

- The base of each McLaughlin cycle is picked at the most prominent dark shale to correspond to a precession maximum close to the peak of the modulating $405 \mathrm{kyr}$ eccentricity variation. The estimated age of 201.5 Ma for the base of McLaughlin cycle 61 used for calibration is remarkably consistent with the calculated phase of the 498th long eccentricity cycle counting back using a period of $405 \mathrm{kyr}$ from the most recent peak at $0.216 \mathrm{Ma}$. Accordingly, we adopt a nomenclature (Ecc405:k) to unambiguously assign ages from the astrochronostratigraphy:

Age $(\mathrm{Ma})=(\mathrm{k}-1) * 0.405+0.216$

where $\mathrm{k}$ is the number of $405 \mathrm{kyr}$ cycles (and fraction thereof) with respect to the peak at $0.216 \mathrm{Ma}$. For example, $\mathrm{k}=498$ for the base of the 


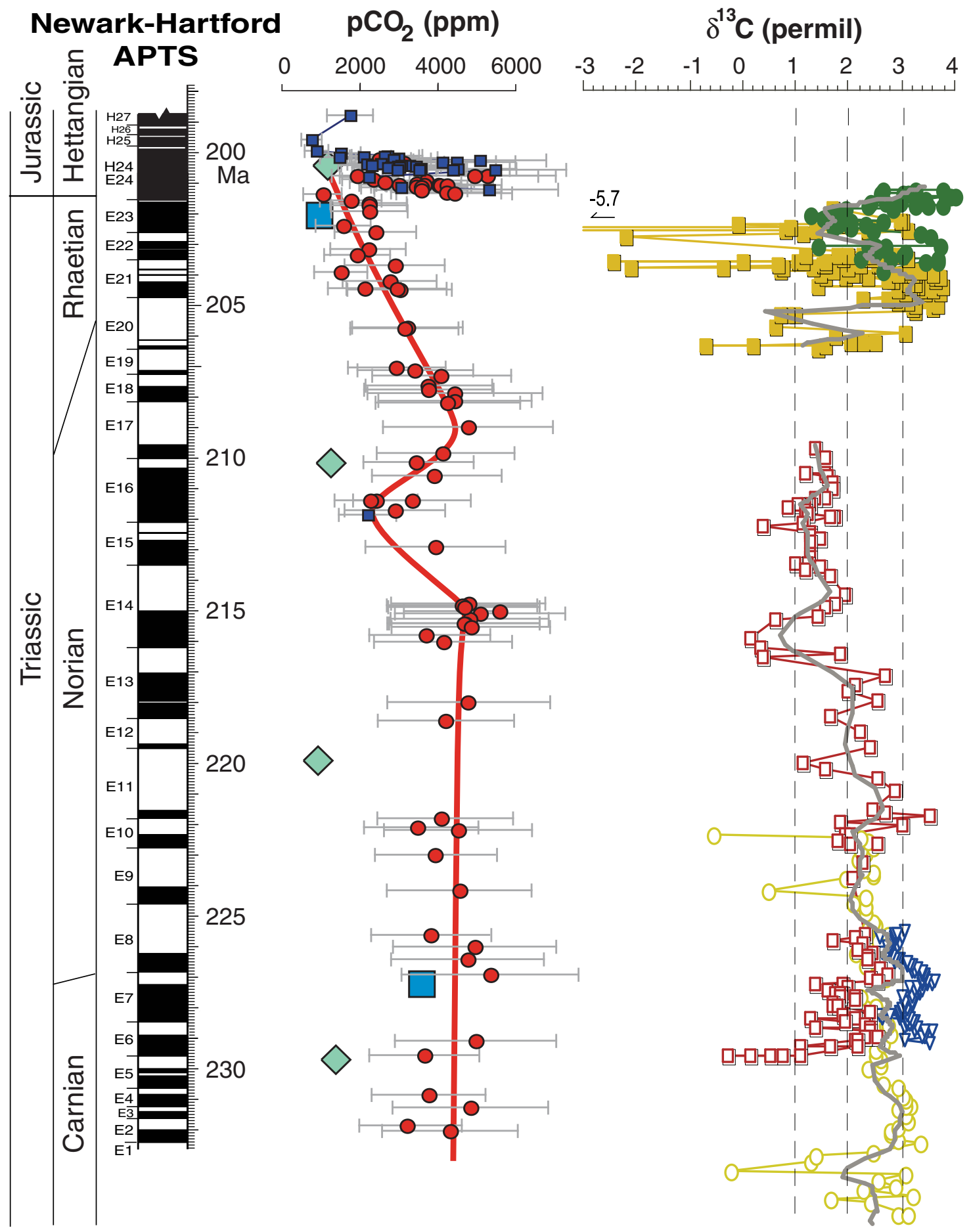

\begin{tabular}{l}
\hline$\square$ paleosol $\mathrm{pCO}_{2}$ data \\
$\square$ GEOCLIM model \\
$\diamond$ GEOCARBSULF model
\end{tabular}

\begin{tabular}{|ll|}
\hline Aghia Marina & Pizzo Mondello \\
$\nabla$ Guri Zi & Italcementi Quarry \\
Brumano & weighted mean \\
\hline
\end{tabular}

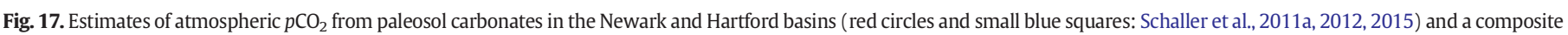

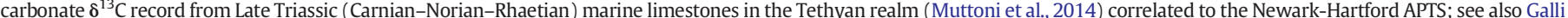

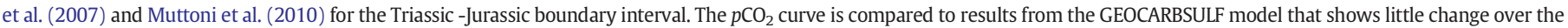

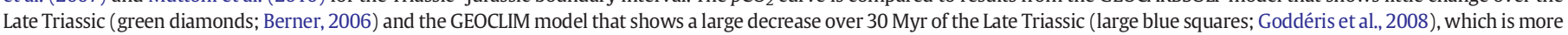
consistent with the measured $p \mathrm{CO}_{2}$ values. 


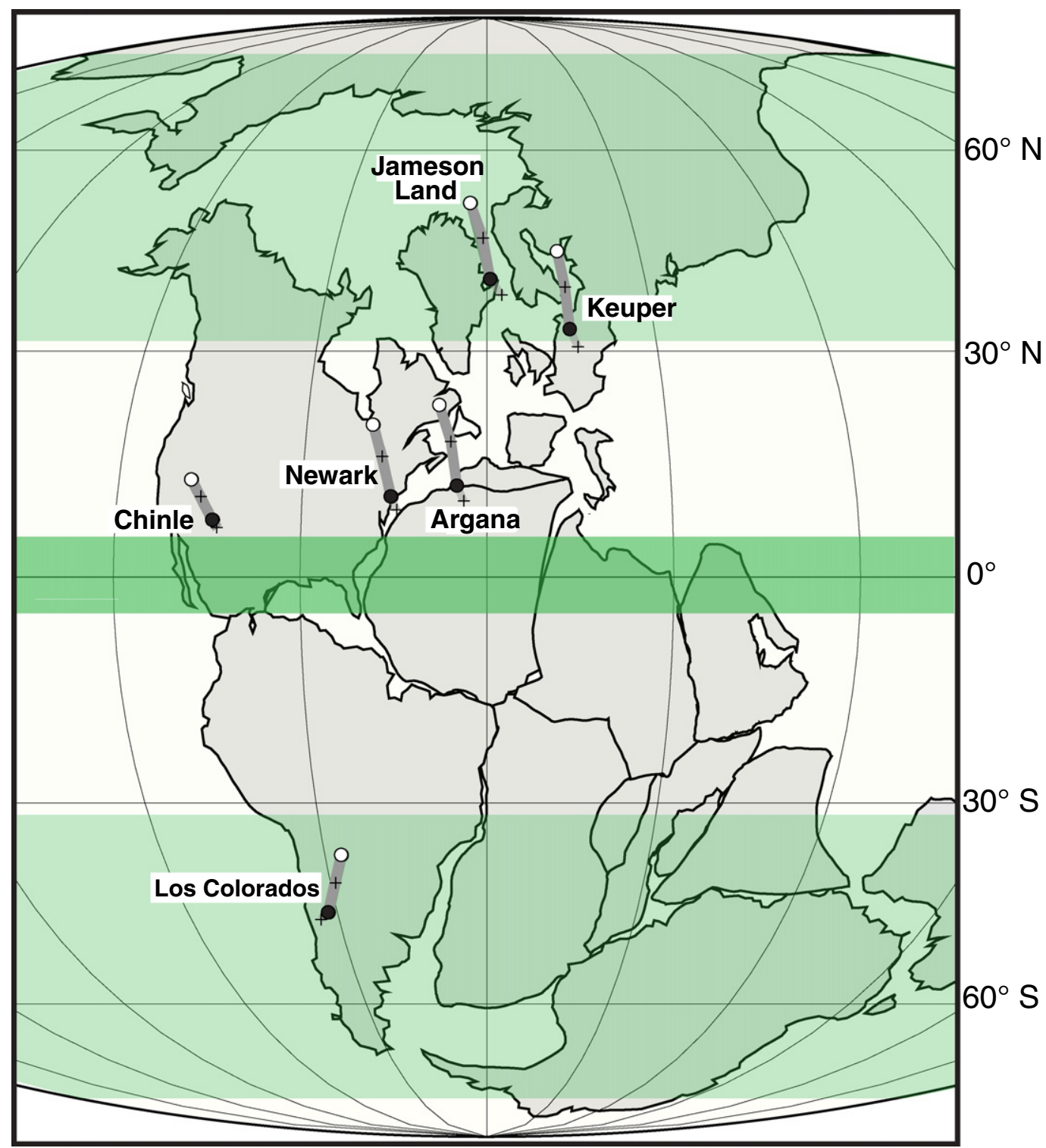

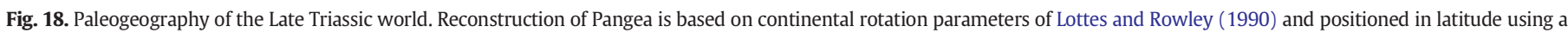

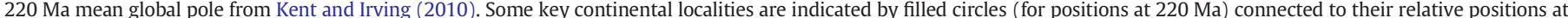

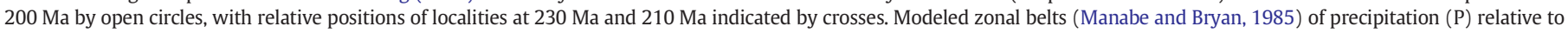
evaporation (E) are indicated by darker and medium green shading for $\mathrm{P}>\mathrm{E}$ (more humid) and lighter shading for $\mathrm{P}<\mathrm{E}$ (more arid). Figure adapted from Kent et al. (2014).

Washington Valley Member and $\mathrm{k}=498.195$ (interpolated) for the base of Chron E23r.

- The portion of the Newark-Hartford APTS that has direct astrochronologic control (Chrons E8n to $\mathrm{H} 27 \mathrm{n}, \mathrm{k}=554.882$ to 492.186, age range 224.54 to $199.15 \mathrm{Ma}$ ) is over $25 \mathrm{Myr}$ long, making it one of the longest continuous astrochronostratigraphic polarity timescales. For example, the Oligocene portion of the Cenozoic APTS is 13 Myr-long (Palike et al., 2006) whereas the rest of the Cenozoic APTS is assembled from shorter segments. However, the astrochronological element of the Newark-Hartford APTS is exceeded in continuous length of record by the 70 Myr-long Triassic-Jurassic Inuyama deep-sea bedded chert sequence of Japan (Ikeda and Tada, 2014) whereas the polarity sequence of the Newark-Hartford APTS is far exceeded in length of record by the $100 \mathrm{Myr}$ (Barremian to Oligocene) geomagnetic polarity history recorded from magnetostratigraphy of the Umbrian Apennines (Lowrie and Alvarez, 1981) and the 180 Myr-long marine magnetic anomaly record of geomagnetic polarity reversals (reviewed by Gee and Kent (2007).

- Triassic stage and substage divisions have classically been erected using ammonoid and/or conodont biostratigraphy from the Tethyan marine realm, often from type areas in the Alps with floating and vague chronologies. Magnetostratigraphic correlation of key Tethyan sections with diagnostic biostratigraphic elements to the Newark-Hartford APTS allows determination of numerical ages of standard marine stages, as follows: $227 \mathrm{Ma}$ for the Carnian/Norian boundary, 205.5 Ma for the Norian/Rhaetian boundary (using a chemostratigraphic criterion, or about $4 \mathrm{Myr}$ older for alternative criteria), and $199.5 \mathrm{Ma}$ for the Hettangian/Sinemurian boundary. The Triassic/Jurassic boundary projects into the Newark-Hartford APTS at 201.4 Ma from the St. Audrie's Bay section. The Triassic/Jurassic boundary, as presently defined, thus post-dates the end-Triassic extinction event by about $200 \mathrm{kyr}$.

- The underlying basis of the Newark-Hartford astrochronology was strongly corroborated by high-precision U-Pb dating of CAMP lavas that bracket cyclic sedimentary units (Blackburn et al., 2013). There is close agreement between relative time from astrochronology and from the high-precision U-Pb dates over the 600 kyr CAMP interval, indicating that orbital signals are faithfully recorded in these lacustrine strata and that solar system dynamics along with the duration of the 
long eccentricity cycles can be reliably modeled that far back. The good agreement between the $230.91 \pm 0.33 \mathrm{Ma} \mathrm{U}-\mathrm{Pb}$ zircon age from an ash layer in late Carnian marine sediments (Furin et al., 2006) with correlatives linked to the Newark-Hartford APTS further validates its ability to apportion time using orbital climate cyclicity over a 30 Myr scale.

- CAMP activity was recognized as representing episodic volcanism over several million years at around 200 Ma based on compilations of ${ }^{40} \mathrm{Ar} /{ }^{39} \mathrm{Ar}$ dates (e.g., Fig. 6 in Knight et al. (2004)). However, highprecision $\mathrm{U}-\mathrm{Pb}$ zircon dating now strongly places CAMP volcanism starting closer to 201.6 Ma and, importantly for its potential environmental impact(s), only about $600 \mathrm{kyr}$ in duration (Blackburn et al., 2013). The ${ }^{40} \mathrm{Ar} /{ }^{39} \mathrm{Ar}$ technique is gradually being normalized with respect to astronomical cycles (Kuiper et al., 2008) and intercalibrated with U-Pb ages (Renne et al., 2010), which should reduce systematic bias arising from comparing ages from different isotopic systems. As one reviewer suggested, some caution should nevertheless be exercised with respect to the high-precision U-Pb ages that are used to anchor the stratigraphic column. The dispersions of high-precision U-Pb dates in some of the cited studies (e.g., Blackburn et al., 2013) are often greater than predicted from analytical uncertainty and may be real, reflecting time-scales of zircon crystallization on the 10-100 kyr level (Caricchi et al., 2014; Ickert et al., 2015). Unresolved open system behavior can also bias ages at the sub-permil level even with the use of chemical abrasion (Mattinson, 2005).

- Suggestions of a cryptic unconformity with a 3 Myr or longer missing interval of Rhaetian time in the Newark basin are incompatible with the recorded presence of Chron E23r immediately below the oldest CAMP basalts in three different basins, which would be totally unexpected from uplift and erosion or nondeposition on the required regional scale. Moreover, magnetostratigraphic correlation of strata with demonstrable Rhaetian affinities at St. Audrie's Bay (Hounslow et al., 2004) to the Newark-Hartford APTS shows there is no evidence for a missing Rhaetian in the Newark Supergroup.

- Paleosol carbonates in the Newark and Hartford basins are an excellent proxy for generating a record of atmospheric $p \mathrm{CO}_{2}$ concentrations that can be registered directly to the Newark-Hartford APTS (Schaller et al., 2015). Tethyan marine carbonate sections with magnetobiostratigraphic constraints for correlation to the NewarkHartford APTS provide a complementary record of carbon cycling from measurements of bulk carbonate $\delta^{13} \mathrm{C}$ (Muttoni et al., 2014). The last few million years of Late Triassic time showed a steady decrease in $p \mathrm{CO}_{2}$ levels that may be due to increasing chemical weathering across the equatorial belt with northward drift of the Pangea landmass. This same interval was also characterized by highly fluctuating $\delta^{13} \mathrm{C}$ values whose origin is unclear.

- The latitudinal gradient in climate at any given time - from polar night, snow fields and even ice sheets to temperate climates, tropical deserts and the equatorial humid belts - probably exceeds climate change at any given place over geological spans of time. This emphasizes the need for differentiating global climate change from changes or differences in latitudinal setting where comparisons and observations are made, especially of terrestrial fauna and flora. The missing Rhaetian assertion, based on apparent temporal delays in appearances and disappearances of palynoflora, conchostracans, and other endemic taxa, is an example in our view of the miscorrelation of ecostratigraphy as chronostratigraphy.

\section{Acknowledgements}

This review is a progress report for over 30 years of our joint and individual work on Triassic problems on continental deposits and more recently, the Tethyan realm. We thank our respective national funding agencies and our institutions for support of our efforts. We appreciate the constructive comments from the two anonymous journal reviewers as well as from the Editor, which helped us to improve the paper. This is a contribution to IGCP 632. LDEO Contribution \#8082.

\section{References}

Benton, M.J., Forth, J., Langer, M.C., 2014. Models for the rise of the Dinosaurs: Review. Curr. Biol. 24, R87-R95.

Berger, A., Loutre, M.F., Laskar, J., 1992. Stability of the astronomical frequencies over the Earth's history for paleoclimate studies. Science 255, 560-566.

Berner, R.A., 2006. GEOCARBSULF: a combined model for Phanerozoic atmospheric $\mathrm{O} 2$ and CO2. Geochim. Cosmochim. Acta 70 (23), 5653-5664.

Bertinelli, A., Casacci, M., Concheri, G., Gattolin, G., Godfrey, L., Katz, M.E., Maron, M., Mazza, M., Mietto, P., Muttoni, G., Rigo, M., Sprovieri, M., Stellin, F., Zaffani, M., 2016. The Norian/Rhaetian boundary interval at Pignola-Abriola section (southern Apennines, Italy) as a GSSP candidate for the Rhaetian Stage: an update. Albertiana 43, 5-18.

Blackburn, T.J., Olsen, P.E., Bowring, S.A., McLean, N.M., Kent, D.V., Puffer, J., McHone, G., Rasbury, E.T., Et-Touhami, M., 2013. Zircon U-Pb geochronology links the End-Triassic extinction with the Central Atlantic Magmatic Province. Science 340, 941-945.

Bloos, G., Page, K.N., 2002. Global stratotype section and point for base of the Sinemurian Stage (Lower Jurassic). Episodes 25, 22-28.

Briden, J.C., Daniels, B.A., 1999. Palaeomagnetic correlation of the Upper Triassic of Somerset, England, with continental Europe and eastern North America. J. Geol. Soc. Lond. 156, 317-326.

Broglio Loriga, C., Cirilli, S., de Zanche, V., di Bari, D., Gianolla, P., Laghi, G.F., Lowrie, W., Manfrin, S., Mastandrea, A., Mietto, P., Muttoni, G., Neri, C., Posenato, R., Reichichi, M., Rettori, R., Roghi, G., 1999. The Prati di Stuores/Stuores Wiesen Section (Dolomites, Italy): a candidate Global Stratotype Section and Point for the base of the Carnian stage. Riv. Ital. Paleontol. Stratigr. 105, 37-78.

Callegaro, S., Rigo, M., Chiaradia, M., Marzoli, A., 2012. Latest Triassic marine Sr isotopic variations, possible causes and implications. Terra Nova:130-135 http://dx.doi.org/ 10.1111/j.1365-3121.2011.01046.x(2).

Cande, S.C., Kent, D.V., 1992. A new geomagnetic polarity time scale for the Late Cretaceous and Cenozoic. J. Geophys. Res. 97, 13,917-13,951.

Cande, S.C., Larson, R.L., LaBrecque, J.L., 1978. Magnetic lineations in the Pacific Jurassic Quiet Zone. Earth Planet. Sci. Lett. 41, 434-440.

Caricchi, L., Simpson, G., Schaltegger, U., 2014. Zircons reveal magma fluxes in the Earth's crust. Nature 511 (7510), 457-461.

Cerling, T.E., 1999. Stable carbon isotopes in paleosol carbonates. In: Thiry, M., SimonCoincon, R. (Eds.), Palaeoweathering, Palaesurfaces and Other Related Continental Deposits. Special Publications of the International Association of Sedimentologists, Oxford, pp. 43-60.

Channell, J.E.T., Lowrie, W., Pialli, P., Venturi, F., 1984. Jurassic magnetic stratigraphy from Umbrian (Italian) land sections. Earth Planet. Sci. Lett. 68, 309-325.

Channell, J.E.T., Erba, E., Nakanishi, M., Tamaki, K., 1995. Late Jurassic-Early Cretaceous time scales and oceanic magnetic anomaly block models. In: Berggren, W.A., Kent, D.V., Aubry, M.-P., Hardenbol, J. (Eds.), Geochronology, Time Scales and Global Stratigraphic Correlations, pp. 51-63.

Channell, J.E.T., Kozur, H.W., Sievers, T., Mock, R., Aubrecht, R., Sykora, M., 2003. CarnianNorian biomagnetostratigraphy at Silicka Brezova (Slovakia): correlation to other Tethyan sections and to the Newark Basin. Palaeogeogr. Palaeoclimatol. Palaeoecol. 191, 65-109.

Channell, J.E.T., Casellato, C.E., Muttoni, G., Erba, E., 2010. Magnetostratigraphy, nannofossil stratigraphy and apparent polar wander for Adria -Africa in the Jurassic-Cretaceous boundary interval. Palaeogeogr. Palaeoclimatol. Palaeoecol. 293, 51-75.

Clemmensen, L.B., Kent, D.V., Jenkins Jr., F.A., 1998. A Late Triassic lake system in East Greenland: facies, depositional cycles and palaeoclimate. Palaeogeogr. Palaeoclimatol. Palaeoecol. 140, 135-159.

Cornet, B., 1993. Applications and limitations of palynology in age, climatic, and paleoenvironmental analyses of Triassic sequences in North America. N. M. Mus. Nat. Hist. Sci. Bull. 3, 75-93.

Cornet, B., Olsen, P.E., 1985. A summary of the biostratigraphy of the Newark Supergroup of eastern North America with comments on Early Mesozoic provinciality. In: Weber, R. (Ed.), Simposio Sobre Floras del Triasico Tardio, su Fitogeografia y Paleoecologia: Memoria, III Congresso Latinoamericano de Paleontologia, Mexico. Instituto de Geologia Universidad Nacional Autonoma de Mexico, Mexico City, pp. 67-81

Cornet, B., Traverse, A., 1975. Palynological contributions to the chronology and stratigraphy of the Hartford Basin in Connecticut and Massachusetts. Geosci. Man 11, $1-33$.

Creer, K.M., 1959. A.C. demagnetization of unstable Triassic Keuper Marls from S.W. England. Geophys. J. R. Astron. Soc. 2, 261-275.

Daikow, L., Orchard, M.J., Friedman, R., 2011. Absolute ages for the Norian Stage: a contribution from southern British Columbia, Canada. In: Haggart, J.W., Smith, P.L. (Eds.), Proceedings of the 21st Canadian Paleontology Conference, Vancouver; CA, pp. 27-28.

Deenen, M.H.L., Ruhl, M., Bonis, N.R., Krijgsman, W., Kuerschner, W.M., Reitsma, M., van Bergen, M.J., 2010. A new chronology for the end-Triassic mass extinction. Earth Planet. Sci. Lett. 291 (1-4), 113-125.

Deenen, M.H.L., Krijgsman, W., Ruhl, M., 2011. The quest for chron E23r at Partridge Island, Bay of Fundy, Canada: CAMP emplacement postdates the end-Triassic extinction event at the North American craton. Can. J. Earth Sci. 48 (8), 1282-1291.

Dessert, C., Dupré, B., Francois, L.M., Schott, J.J., Gaillardet, J., Chakrapani, G., Bajpai, S., 2001. Erosion of Deccan Traps determined by river geochemistry: impact on the global climate and the $87 \mathrm{Sr} / 86 \mathrm{Sr}$ ratio of seawater. Earth Planet. Sci. Lett. $188,459-474$. 
Diakow, L., Orchard, M.J., Friedman, R., 2012. Absolute ages for the Norian Stage: a further contribution from southern British Columbia, Canada. Cordilleran Tectonics Workshop. Geological Association Canada, Pacific Section, p. 2.

Donohoo-Hurley, L.L., Geissman, J.W., Lucas, S.G., 2010. Magnetostratigraphy of the uppermost Triassic and lowermost Jurassic Moenave Formation, western United States: Correlation with strata in the United Kingdom, Morocco, Turkey, Italy, and eastern United States. Geol. Soc. Am. Bull. 122 (11/12), 1936-1950.

Font, E., Youbi, N., Fernandes, S., Hachimi, H.E., Kratinove, Z., Hamim, Y., 2011. Revisiting the magnetostratigraphy of the Central Atlantic Magmatic Province (CAMP) in Morocco. Earth Planet. Sci. Lett. 309, 302-317.

Fowell, S.J., Olsen, P.E., 1993. Time calibration of Triassic/Jurassic microfloral turnover, eastern North America. Tectonophysics 222, 361-369.

Frakes, L.A., Francis, J.E., 1988. A guide to Phanerozoic cold polar climates from highlatitude ice-rafting in the Cretaceous. Nature 333, 547-549.

Furin, S., Preto, N., Rigo, M., Roghi, G., Gianolla, P., Crowley, J.L., Bowring, S.A., 2006. Highprecision $\mathrm{U}-\mathrm{Pb}$ zircon age from the Triassic of Italy: Implications for the Triassic time scale and the Carnian origin of calcareous nannoplankton and dinosaurs. Geology 34, 1009-1012.

Gallet, Y., Krystyn, L., Besse, J., 1998. Upper Anisian to Lower Carnian magnetostratigraphy from the Northern Calcareous Alps (Austria). J. Geophys. Res. 103, 605-621.

Gallet, Y., Krystyn, L., Marcoux, J., Besse, J., 2007. New constraints on the End-Triassic (Upper Norian-Rhaetian) magnetostratigraphy. Earth Planet. Sci. Lett. 255 (3-4), 458-470.

Galli, M.T., Jadoul, F., Bernasconi, S.M., Cirilli, S., Weissert, H., 2007. Stratigraphy and palaeoenvironmental analysis of the Triassic-Jurassic transition in the western Southern Alps (Northern Italy). Palaeogeogr. Palaeoclimatol. Palaeoecol. 244, 52-70.

Gee, J.S., Kent, D.V., 2007. Source of oceanic magnetic anomalies and the geomagnetic polarity time scale. In: Kono, M. (Ed.), Treatise on Geophysics. Elsevier, Amsterdam, pp. 455-507.

Gehrels, G.E., Saleeby, J.B., Berg, H.C., 1987. Geology of Annette, Gravina, and Duke islands, southeastern Alaska. Can. J. Earth Sci. 24, 866-881.

Goddéris, Y., Donnadieu, Y., de Vargas, C., Pierrehumbert, R.T., Dromart, G., van de Schootbrugge, B., 2008. Causal or casual link between the rise of nannoplankton calcification and a tectonically-driven massive decrease in Late Triassic atmospheric CO2? Earth Planet. Sci. Lett. 267 (1-2), 247-255.

Goldberg, D., Reynolds, D., Williams, C., Witte, W.K., Olsen, P.E., Kent, D.V., 1994. Well logging results from the Newark Basin Coring Project (NBCP). Sci. Drill. 4, 267-279.

Golding, M.L., Mortensen, J.K., Zonneveld, J.-P., Orchard, M.J., 2016. U-Pb isotopic ages of euhedral zircons in the Rhaetian of British Columbia: Implications for Cordilleran tectonics during the Late Triassic. Geosphere 12 (5), 1606-1616.

Golebiowski, R., 1990. The Alpine Kössen Formation: a key for European topmost Triassic correlations. Albertiana 8, 25-35.

Gradstein, F.M., Agterberg, F.P., Ogg, J.G., Hardenbol, J., Van Veen, P., Thierry, J., Huang, Z., 1994. A Mesozoic time scale. J. Geophys. Res. 99, 24,051-24,074.

Gradstein, F.M., Ogg, J.G., Smith, A.G. (Eds.), 2004. A Geologic Time Scale 2004. Cambridge University Press, Cambridge (589 pp.).

Gradstein, F.M., Ogg, J.G., Schmitz, M.D., Ogg, G.M. (Eds.), 2012. The Geologic Time Scale 2012. Elsevier, Amsterdam (1144 pp.).

Guex, J., Schoene, B., Bartolini, A., Spangenberg, J., Schaltegger, U., O'Dogherty, L., Taylor, D., Bucher, H., Atudorei, V., 2012. Geochronological constraints on post-extinction recovery of the ammonoids and carbon cycle perturbations during the Early Jurassic. Palaeogeogr. Palaeoclimatol. Palaeoecol. 346-347, 1-11.

Harland, W.B., Cox, A.V., Llewellyn, P.G., Pickton, C.A.G., Smith, A.G., Walters, R., 1982. A Geologic Time Scale. Cambridge University Press, Cambridge (131 pp.).

Hesselbo, S.P., Robinson, S.A., Surlyk, F., Piasecki, S., 2002. Terrestrial and marine extinction at the Triassic-Jurassic boundary synchronized with major carbon-cycle perturbation: a link to initiation of massive volcanism? Geology 30, 251-254.

Hillebrandt, A.v., Krystyn, L., Kuerschner, W.M., Bonis, N.R., Ruhl, M., Richoz, S., Schobben, M.A.N., Urlichs, M., Bown, P.R., Kment, K., McRoberts, C.A., Simms, M., Tomãsových, A. 2013. The Global Stratotype Sections and Point (GSSP) for the base of the Jurassic System at Kuhjoch (Karwendel Mountains, Northern Calcareous Alps, Tyrol, Austria). Episodes 36, 162-198.

Hounslow, M.W., Muttoni, G., 2010. The geomagnetic polarity timescale for the Triassic: linkage to stage boundary definitions. Geol. Soc. Lond. Spec. Publ. 334, 61-102.

Hounslow, M.W., Posen, P.E., Warrington, G., 2004. Magnetostratigraphy and biostratigraphy of the Upper Triassic and lowermost Jurassic succession, St. Audrie's Bay, UK. Palaeogeogr. Palaeoclimatol. Palaeoecol. 213, 331-358.

Huber, P., Lucas, S.G., Hunt, A.P., 1993. Vertebrate biochronology of the Newark Supergroup Triassic, eastern North America. N. M. Mus. Nat. Hist. Sci. Bull. 3, 179-186.

Hubert, J.F., Mertz, K.A., 1980. Eolian dune field of Late Triassic age, Fundy Basin, Nova Scotia. Geology 8, 516-519.

Hubert, J.F., Feshbach-Meriney, P.E., Smith, M.A., 1992. The Triassic-Jurassic Hartford Rift Basin, Connecticut and Massachusetts: evolution, sandstone diagenesis, and hydrocarbon history. Am. Assoc. Pet. Geol. Bull. 76, 1710-1734.

Hüsing, S.K., Deenen, M.H.L., Koopmans, J.G., Krijgsman, W., 2011. Magnetostratigraphic dating of the proposed Rhaetian GSSP at Steinbergkogel (Upper Triassic, Austria): implications for the Late Triassic time scale. Earth Planet. Sci. Lett. 302 (1-2), 203-216.

Hüsing, S.K., Beniest, A., Boon, A.v.d., Abels, H.A., Deenen, M.H.L., Ruhl, M., Krijgsman, W., 2014. Astronomically-calibrated magnetostratigraphy of the Lower Jurassic marine successions at St. Audries Bay and East Quantoxhead (Hettangian-Sinemurian; Somerset, UK). Palaeogeogr. Palaeoclimatol. Palaeoecol. 403, 43-56.

Ickert, R.B., Mundil, R., Magee, C.W., Mulcahy, S.R., 2015. The U-Th-Pb systematics of zircon from the Bishop Tuff: a case study in challenges to high-precision $\mathrm{Pb} / \mathrm{U}$ geochronology at the millennial scale. Geochim. Cosmochim. Acta 168, 88-110.
Ikeda, M., Tada, R., 2014. A 70 million year astronomical time scale for the deep-sea bedded chert sequence (Inuyama, Japan): implications for Triassic-Jurassic geochronology. Earth Planet. Sci. Lett. 399, 30-43.

Kent, D.V., Clemmensen, L.B., 1996. Paleomagnetism and cycle stratigraphy of the Triassic Fleming Fjord and Gipsdalen Formations of East Greenland. Bull. Geol. Soc. Den. 42, 121-136.

Kent, D.V., Irving, E., 2010. Influence of inclination error in sedimentary rocks on the Triassic and Jurassic apparent polar wander path for North America and implications for Cordilleran tectonics. J. Geophys. Res. 115, B10103. http://dx.doi.org/10.1029/ 2009JB007205.

Kent, D.V., Olsen, P.E., 1997. Paleomagnetism of Upper Triassic continental sedimentary rocks from the Dan River-Danville rift basin (eastern North America). Geol. Soc. Am. Bull. 109, 366-377.

Kent, D.V., Olsen, P.E., 1999. Astronomically tuned geomagnetic polarity time scale for the Late Triassic. J. Geophys. Res. 104 (B6), 12831-12841.

Kent, D.V., Olsen, P.E., 2000. Magnetic polarity stratigraphy and paleolatitude of the Triassic-Jurassic Blomidon Formation in the Fundy basin (Canada): implications for early Mesozoic tropical climate gradients. Earth Planet. Sci. Lett. 179, 311-324.

Kent, D.V., Olsen, P.E., 2008. Early Jurassic magnetostratigraphy and paleolatitudes from the Hartford continental rift basin (eastern North America): testing for polarity bias and abrupt polar wander in association with the Central Atlantic Magmatic Province. J. Geophys. Res. 113, B06105. http://dx.doi.org/10.1029/2007JB005407.

Kent, D.V., Tauxe, L., 2005. Corrected Late Triassic latitudes for continents adjacent to the North Atlantic. Science 307, 240-244.

Kent, D.V., Olsen, P.E., Witte, W.K., 1995. Late Triassic-earliest Jurassic geomagnetic polarity sequence and paleolatitudes from drill cores in the Newark rift basin, eastern North America. J. Geophys. Res. 100, 14,965-14,998.

Kent, D.V., Santi Malnis, P., Colombi, C.E., Alcober, O.A., Martínez, R.N., 2014. Age constraints on the dispersal of dinosaurs in the Late Triassic from magnetochronology of the Los Colorados Formation (Argentina). Proc. Natl. Acad. Sci. 111 (22), 7958-7963.

Knight, K.B., Nomade, S., Renne, P.R., Marzoli, A., Bertrand, H., Youbi, N., 2004. The Central Atlantic Magmatic Province at the Triassic-Jurassic boundary: paleomagnetic and $40 \mathrm{Ar} / 39 \mathrm{Ar}$ evidence from Morocco for brief, episodic volcanism. Earth Planet. Sci. Lett. 228, 143-160

Kozur, H.W., 2003. Micropaleontological definition of the Norian-Rhaetian boundary, IGCP 458 Triassic/Jurassic boundary events: extinction events, faunal turnovers and natural boundaries within and around the Late Triassic. Geological Association of Canada Mineralogical Association of Canada and Society of Economic Geologists Annual Meeting, Vancouver Canada.

Kozur, H.W., Weems, R.E., 2010. The biostratigraphic importance of conchostracans in the continental Triassic of the northern hemisphere. In: Lucas, S.G. (Ed.), The Triassic Timescale. Geological Society, London, Special Publications, pp. 315-417.

Krystyn, L., Gallet, Y., Besse, J., Marcoux, J., 2002. Integrated Upper Carnian to Lower Norian biochronology and implications for the Upper Triassic magnetic polarity time scale. Earth Planet. Sci. Lett. 203, 343-351.

Kuerschner, W.M., Bonis, N.R., Krystyn, L., 2007. Carbon-isotope stratigraphy and palynostratigraphy of the Triassic-Jurassic transition in the Tiefengraben section Northern Calcareous Alps (Austria). Palaeogeogr. Palaeoclimatol. Palaeoecol. 244 (1-4), 257-280.

Kuiper, K.F., Deino, A., Hilgen, F.J., Krijgsman, W., Renne, P.R., Wijbrans, J.R., 2008. Synchronizing rock clocks of Earth history. Science 320, 500-504.

Laskar, J., 1990. The chaotic motion of the Solar System: a numerical estimate of the size of the chaotic zones. Icarus 88, 266-291.

Laskar, J., Robutel, P., Joutel, F., Gastineau, M., Correia, A.C.M., Levrard, B., 2004. A longterm numerical solution for the insolation quantities of the Earth. Astron. Astrophys 428, 261-285.

Laskar, J., Fienga, A., Gastineau, M., Manche, H., 2011. La2010: a new orbital solution for the long-term motion of the Earth. Astron. Astrophys. 532, A89.

LeTourneau, P.M., 2003. Stratigraphic architecture and paleomagnetic reversal stratigraphy of the Late Triassic Taylorsville Basin, Virginia and Maryland. In: LeTourneau, P.M., Olsen, P.E. (Eds.), The Great Rift Valleys of Pangea in Eastern North AmericaSedimentology, Stratigraphy, and Paleontology vol. 2. Columbia University Press, New York, pp. 12-18.

LeTourneau, P.M., Huber, P., 2006. Early Jurassic eolian dune field, Pomperaug basin, Connecticut and related synrift deposits: stratigraphic framework and paleoclimatic context. Sediment. Geol. 187, 63-81.

Lottes, A.L., Rowley, D.B., 1990. Reconstruction of the Laurasian and Gondwanan segments of Permian Pangaea. In: McKerrow, W.S., Scotese, C.R. (Eds.), Palaeozoic Palaeogeography and Biogeography, Memoir 12. Geological Society, London, pp. 383-395.

Lowrie, W., Alvarez, W., 1981. One hundred million years of geomagnetic polarity history Geology 9, 392-397.

Lucas, S.G., 2010. The Triassic timescale based on nonmarine tetrapod biostratigraphy and biochronology. Geol. Soc. Lond. Spec. Publ. 334, 447-500.

Malinverno, A., Hildebrandt, J., Tominaga, M., Channell, J.E.T., 2012. M-sequence geomagnetic polarity time scale (MHTC12) that steadies global spreading rates and incorporates astrochronology constraints. J. Geophys. Res. 117. http://dx.doi.org/10.1029/ 2012JB009260.

Manabe, S., Bryan, K., 1985. CO2-induced change in a coupled ocean-atmosphere model and its paleoclimatic implications. J. Geophys. Res. 90 (C6), 11689-11707.

Maron, M., Rigo, M., Bertinelli, A., Katz, M.E., Godfrey, L., Zaffani, M., Muttoni, G., 2015 Magnetostratigraphy, biostratigraphy, and chemostratigraphy of the PignolaAbriola section: new constraints for the Norian-Rhaetian boundary. Geol. Soc. Am. Bull. 127 (7-8), 962-974.

Marzoli, A., Renne, P.R., Piccirillo, E.M., Ernesto, M., Gellieni, G., De Min, A., 1999. Extensive 200-million-year-old continental flood basalts of the Central Atlantic Magmatic Province. Science 284, 616-618. 
Marzoli, A., Bertrand, H., Knight, K.B., Cirilli, S., Buratti, N., Verati, C., Nomade, S., Renne, P.R., Youbi, N., Martini, R., Allenbach, K., Neuwerth, R., Rapaille, C., Zaninetti, L., Bellieni, G., 2004. Synchrony of the Central Atlantic magmatic province and the Triassic-Jurassic boundary climatic and biotic crisis. Geology 32, 973-976.

Marzoli, A., Bertrand, H., Knight, K.B., Cirilli, S., Nomade, S., Renne, P.R., Verati, C., Youbi, N., Martini, R., Bellieni, G., 2008. Comment on "Synchrony between the Central Atlantic magmatic province and the Triassic-Jurassic mass-extinction event? By Whiteside et al. (2007)". Palaeogeogr. Palaeoclimatol. Palaeoecol. 262, 189-193.

Mattinson, J.M., 2005. Zircon U-Pb chemical abrasion ("CA-TIMS") method: combined annealing and multi-step partial dissolution analysis for improved precision and accuracy of zircon ages. Chem. Geol. 220, 47-66.

Mayall, M.J., 1983. An earthquake origin for syn-sedimentary deformation in a late Triassic (Rhaetian) lagoonal sequence, southwest Britain. Geol. Mag. 120, 613-622.

Mazza, M., Rigo, M., 2012. Taxonomy and biostratigraphic record of the Upper Triassic conodonts of the Pizzo Mondello section (Western Sicily, Italy), GSSP candidate fo the base of the Norian. Riv. Ital. Paleontol. Stratigr. 118 (1).

McElhinny, M.W., Burek, P.J., 1971. Mesozoic paleomagnetic stratigraphy. Nature 232, 98-102.

McElhinny, M.W., Larson, R.L., 2003. Jurassic dipole low defined from land and sea data. Eos. Trans. AGU 84 (37), 362-366.

McElwain, J.C., Beerling, D.J., Woodward, F.I., 1999. Fossil plants and global warming at the Triassic-Jurassic boundary. Science 285, 1386-1390.

McElwain, J.C., Popa, M.E., Hesselbo, S.P., Haworth, M., Surlyk, F., 2007. Macroecological responses of terrestrial vegetation to climatic and atmospheric change across the Triassic/Jurassic boundary in East Greenland. Paleobiology 33 (4), 547-573.

McIntosh, W.C., Hargraves, R.B., West, C.L., 1985. Paleomagnetism and oxide mineralogy of upper Triassic to lower Jurassic red beds and basalts in the Newark Basin. Geol. Soc. Am. Bull. 96, 463-480

McLaughlin, D.B., 1943. The Revere well and Triassic stratigraphy, Pennsylvania. Acad. Sci. Proc. 17, 104-110 (Acad. Sci. Proc.)

McLaughlin, D.B., 1945. Type sections of the Stockton and Lockatong Formations. Proc Acad. Sci Pennsylvania 19, 1102-1113.

McLaughlin, D.B., 1959. Mesozoic rocks. Pennsylvania Geol. Surv. Bull. C-9, 55-114.

Meyers, S.R., 2008. Resolving Milankovitchian controversies: the Triassic Latemar Limestone and the Eocene Green River Formation. Geology 36, 319-322.

Mietto, P., Manfrin, S., Preto, N., Rigo, M., Roghi, G., Furin, S., Gianolla, P., Posenato, R. Muttoni, G., Nicora, A., Buratti, N., Cirilli, S., Spötl, C., Ramezani, J., Bowring, S.A 2012. The Global Boundary Stratotype Section and Point (GSSP) of the Carnian Stage (Late Triassic) at Prati di Stuores/Stuores Wiesen Section (Southern Alps, NE Italy). Episodes 35, 414-430.

Minzoni, M., Lehrmann, D.J., Dezoeten, E., Enos, P., Montgomery, P., Berry, A., Qin, Y., Meiyi, Y., Ellwood, B.B., Payne, J.L., 2015. Drowning of the Triassic Yangtze Platform, South China, by tectonic subsidence into toxic deep waters of an anoxic basin J. Sediment. Res. 85 (5), 419-444.

Molina-Garza, R.S., Geissman, J.W., Van der Voo, R., Lucas, S.G., Hayden, S.N., 1991. Paleomagnetism of the Moenkopi and Chinle Formations in central New Mexico: implications for the North American apparent polar wander path and Triassic magnetostratigraphy. J. Geophys. Res. 96, 14,239-14,262.

Molina-Garza, R.S., Geissman, J.W., Lucas, S., 2003. Paleomagnetism and magnetostratigraphy of the lower Glen Canyon and upper Chinle Groups, JurassicTriassic of northern Arizona and northeast Utah. J. Geophys. Res. 108 (B4). http:// dx.doi.org/10.1029/2002JB001909.

Mundil, R., Palfy, J., Renne, P.R., Brack, P., 2010. The Triassic timescale: new constraints and a review of geochronological data. In: Lucas, S.G. (Ed.), The Triassic TimescaleSpecial Publication Vol. 334. Geological Society, London, pp. 41-60.

Muttoni, G., Kent, D.V., Olsen, P.E., DiStefano, P., Lowrie, W., Bernasconi, S., Hernandez F.M., 2004a. Tethyan magnetostratigraphy from Pizzo Mondello (Sicily) and correlation to the Late Triassic Newark astrochronological polarity time scale. Geol. Soc. Am Bull. 116 (9/10), 1043-1058.

Muttoni, G., Nicora, A., Brack, P., Kent, D.V., 2004b. Integrated Anisian-Ladinian boundary chronology. Palaeogeogr. Palaeoclimatol. Palaeoecol. 208, 85-102.

Muttoni, G., Kent, D.V., Jadoul, F., Olsen, P.E., Rigo, M., Galli, M.T., Nicora, A., 2010. Rhaetian magnetobiostratigraphy from the Southern Alps (Italy): constraints on Triassic chronology. Palaeogeogr. Palaeoclimatol. Palaeoecol. 285, 1-16.

Muttoni, G., Mazza, M., Mosher, D., Katz, M.E., Kent, D.V., Balini, M., 2014. A Middle-Late Triassic (Ladinian-Rhaetian) carbon and oxygen isotope record from the Tethyan Ocean. Palaeogeogr. Palaeoclimatol. Palaeoecol. 399, 246-259.

Ogg, J.G., 2012. Triassic. In: Gradstein, F.M., Ogg, J.G., Schmitz, M., Ogg, G. (Eds.), The Geological Time Scale 2012. Elsevier, Amsterdam, pp. 681-730.

Olsen, P.E., 1980. The latest Triassic and Early Jurassic formations of the Newark basin (Eastern North America, Newark Supergroup): stratigraphy, structure, and correlation. N. J. Acad. Sci. Bull. 25, 25-51.

Olsen, P.E., 1986. A 40-million-year lake record of early Mesozoic orbital climatic forcing Science 234, 842-848 (Science).

Olsen, P.E. 1990. Tectonic, climatic, and biotic modulations of lacustrine ecosystems - examples from Newark Supergroup of eastern North America. In: Katz BJ. (Ed.). Lacustrine Basin, Exploration Case Studies and Modern Analogs. American Association of Petroleum Geologists, Tulsa, OK, pp. 209-224

Olsen, P.E., 1997. Stratigraphic record of the early Mesozoic breakup of Pangea in the Laurasia-Gondwana rift system. Annu. Rev. Earth Planet. Sci. 25, 337-401.

Olsen, P.E., Cornet, B., 1988. The Triassic/Jurassic boundary in eastern North America, Global Catastrophes in Earth History. Lunar and Planetary Institute-Nationa Academy of Sciences, Snowbird, Utah, pp. 135-136.
Olsen, P.E., Kent, D.V., 1996. Milankovitch climate forcing in the tropics of Pangea during the Late Triassic. Palaeogeogr. Palaeoclimatol. Palaeoecol. 122, 1-26.

Olsen, P.E., Kent, D.V., 1999. Long-period Milankovitch cycles from the Late Triassic and Early Jurassic of eastern North America and their implications for the calibration of the Early Mesozoic time-scale and the long-term behaviour of the planets. Philos. Trans. R. Soc. Lond. Ser. A 357, 1761-1786.

Olsen, P.E., Kent, D.V., Cornet, B., Witte, W.K., Schlische, R.W., 1996a. High-resolution stratigraphy of the Newark rift basin (early Mesozoic, eastern North America). Geol. Soc. Am. Bull. 108, 40-77.

Olsen, P.E., Schlische, R.W., Fedosh, M.S., 1996b. 580 Ky duration of the Early Jurassic flood basalt event in eastern North America estimated using Milankovitch cyclostratigraphy. In: Morales, M. (Ed.), The Continental Jurassic. Museum of Northern Arizona, pp. 11-22.

Olsen, P.E., Kent, D.V., Sues, H.-D., Koeberl, C., Huber, H., Montanari, A., Rainforth, E.C., Fowell, S.J., Szajna, M.J., Hartline, B.W., 2002a. Ascent of dinosaurs linked to an iridium anomaly at the Triassic-Jurassic boundary. Science 296, 1305-1307.

Olsen, P.E., Koeberl, C., Huber, H., Montanari, A., Fowell, S.J., Et Touhami, M., Kent, D.V., 2002b. Continental Triassic-Jurassic boundary in central Pangea: recent progress and discussion of an Ir anomaly. Geol. Soc. Am. Spec. Pap. 356, 505-522.

Olsen, P.E., Kent, D.V., Et-Touhami, M., Puffer, J., 2003. Cyclo-, magneto-, and biostratigraphic constraints on the duration of the CAMP event and its relationship to the Triassic-Jurassic Boundary. In: Hames, W.E., McHone, J.G., Renne, P.R., Ruppel, C. (Eds.), The Central Atlantic Magnatic Province: Insights from Fragments of Pangea. American Geophysical Union, Washington, DC, pp. 7-32.

Olsen, P.E., Kent, D.V., Whiteside, J.H., 2011. Implications of the Newark Supergroup-based astrochronology and geomagnetic polarity time scale (Newark-APTS) for the tempo and mode of the early diversification of the Dinosauria. Trans. R. Soc. Edinb. Earth Sci. 101, 201-229.

Olsen, P.E., Reid, J.C., Taylor, K., Whiteside, J.H., Kent, D.V., 2015. Revised Stratigraphy of Late Triassic Age Strata of the Dan River Basin (Virginia and North Carolina, USA) based on drill core and outcrop data. Southeast. Geol. 51, 1-31.

Opdyke, N.D., 1961. The paleomagnetism of the New Jersey Triassic: a field study of the inclination error in red sediments. J. Geophys. Res. 66, 1941-1949.

Paillard, D., Labeyrie, L., Yiou, P., 1996. Macintosh program performs time-series analysis. Eos Trans. AGU 77, 379

Palike, H., Norris, R.D., Herrle, J.O., Wilson, P.A., Coxall, H.K., Lear, C.H., Shackleton, N.J., Tripati, A.K., Wade, B.S., 2006. The heartbeat of the Oligocene climate system. Science 314, 1894-1898.

Perchersky, D.M., Khramov, A.N., 1973. Mesozoic Palaeomagnetic Scale of the USSR. Nature 244, 499-501.

Prevot, M., McWilliams, M., 1989. Paleomagnetic correlation of the Newark Supergroup volcanics. Geology 17, 1007-1010.

Renne, P.R., Mundil, R., Balco, G., Min, K., Ludwig, K.R., 2010. Joint determination of $40 \mathrm{~K}$ decay constants and $40 \mathrm{Ar} / 40 \mathrm{~K}$ for the Fish Canyon sanidine standard, and improved accuracy for $40 \mathrm{Ar} / 39 \mathrm{Ar}$ geochronology. Geochim. Cosmochim. Acta 74, 5349-5367.

Reynolds, D.J., 1993. Sedimentary Basin Evolution: Tectonic and Climatic Interaction. Columbia University, New York.

Rigo, M., Preto, N., Franceschi, M., Guaiumi, C., 2012. Stratigraphy of the Carnian-Norian Calcari con Selce Formation in the Lagonegro Basin, southern Apennines. Riv. Ital. Paleontol. Stratigr. 118, 143-154.

Royer, D.L., 2006. CO2-forced climate thresholds during the Phanerozoic. Geochim. Cosmochim. Acta 70, 5665-5675.

Ruhl, M., Deenen, M.H.L., Abels, H.A., Bonis, N.R., Krijgsman, W., Kurschner, W.M. 2010. Astronomical constraints on the duration of the early Jurassic Hettangian stage and recovery rates following the end-Triassic mass extinction (St Audrie's Bay/East Quantoxhead, UK). Earth Planet. Sci. Lett. 295 (1-2), 262-276.

Sager, W.W., Weiss, M.A., Tivey, M.A., Johnson, H.P., 1998. Geomagnetic polarity reversal model of deep-tow profiles from the Pacific Jurassic "Quiet Zone". J. Geophys. Res. 103, 5269-5286.

Schaller, M.F., Wright, J.D., Kent, D.V., 2011a. Atmospheric pCO2 perturbations associated with the Central Atlantic Magmatic Province. Science 331, 1404-1409.

Schaller, M.F., Wright, J.D., Kent, D.V., 2011b. Response to Comment on "Atmospheric pCO2 Perturbations Associated with the Central Atlantic Magmatic Province " by M. R. Rampino and K. Caldeira. Science 334, 594-c.

Schaller, M.F., Wright, J.D., Kent, D.V., Olsen, P.E., 2012. Rapid emplacement of the Central Atlantic Magmatic Province as a net sink for CO2. Earth Planet. Sci. Lett. 323-324, 27-39.

Schaller, M.F., Wright, J.D., Kent, D.V., 2015. A 30 million-year record of Late Triassic pCO2 variation supports a fundamental control of the carbon-cycle by changes in continental weathering. Geol. Soc. Am. Bull. 127, 661-671.

Schaltegger, U., Guex, J., Bartolini, A., Schoene, B., Ovtcharov, M., 2008. Precise U-Pb age constraints for end-Triassic mass extinction, its correlation to volcanism and Hettangian post-extinction recovery. Earth Planet. Sci. Lett. 267, 266-275.

Schoene, B., Guex, J., Bartolini, A., Schaltegger, U., Blackburn, T.J., 2010. Correlating the end-Triassic mass extinction and flood basalt volcanism at the 100,000-year level. Geology 38, 387-390

Sha, J., Olsen, P.E., Xu, D., Yao, X., Pan, Y., Wang, Y., Zhang, X., Vajda, V., 2015. Early Mesozoic, high-latitude continental Triassic-Jurassic climate in high-latitude Asia was dominated by obliquity-paced variations (Junggar Basin, Urumqi, China). Proc. Natl. Acad. Sci. 112 (12), 3624-3629.

Speranza, F., Satolli, S., Mattioli, E., Calamita, F., 2005. Magnetic stratigraphy of Kimmeridgian-Aptian sections from Umbria-Marche (Italy): new details on the M polarity sequence. J. Geophys. Res. 110, B12109. http://dx.doi.org/10.1029/2005JB003884.

Steinen, R., Martin, L.G., Conti, A., Jorgensen, C., Gierlowski-kordesch, E.H., 2015. Stratigraphic observations on cored boreholes in the Mesozoic Hartford basin, Hartford, Connecticut. Geol. Soc. Am. Abstr. Programs 47 (3), 54 
Steiner, M.B., Lucas, S.G., 2000. Paleomagnetism of the Late Triassic Petrified Forest Formation, Chinle Group, western United States: further evidence of "large" rotation of the Colorado Plateau. J. Geophys. Res. 105, 25,791-25,808.

Steiner, M., Ogg, J.G., Sandoval, J., 1987. Jurassic magnetostratigraphy, 3. BathonianBajocian of Carcabuey, Sierra Harana and Campillo de Arenas (Subbetic Cordiller, southern Spain). Earth Planet. Sci. Lett. 82, 357-372.

Swift, A., Martill, D.M. (Eds.), 1999. Fossils of the Rhaetian Penarth group, 9. The Palaeontological Association, Blackwell, London (312 pp.).

Tanner, L.H., Lucas, S.G., 2015. The Triassic-Jurassic strata of the Newark Basin, USA: a complete and accurate astronomically-tuned timescale? Stratigrapthy 12 (1), 47-65.

Tominaga, M., Sager, W.W., 2010. Revised Pacific M-anomaly geomagnetic polarity timescale. Geophys. J. Int. 182 (1), 203-232.

Tominaga, M., Sager, W.W., Tivey, M.A., Lee, S.-M., 2008. Deep-tow magnetic anomaly study of the Pacific Jurassic Quiet Zone and implications for the geomagnetic polarity reversal timescale and geomagnetic field behavior. J. Geophys. Res. Solid Earth 113 (B7), B07110.

Van Houten, F.B., 1964. Cyclic lacustrine sedimentation Upper Triassic Lockatong Formation, central New Jersey and adjacent Pennsylvania. Kansas Geol. Surv. Bull. 169, 497-531.

Van Veen, P.M., 1995. Time calibration of Triassic/Jurassic microfloral turnover, eastern North America -Comment. Tectonophysics 245, 91-95.

Veizer, J., Godderis, Y., Francois, L.M., 2000. Evidence for decoupling of atmospheric CO2 and global climate during the Phanerozoic eon. Nature 408, 698-701.

Webb, J.A., 1981. A radiometric time scale of the Triassic. J. Geol. Soc. Aust. 28, 107-121. Weems, R.E., Olsen, P.E., 1997. Synthesis and revision of groups within the Newark Supergroup, eastern North America. Geol. Soc. Am. Bull. 109, 195-209.

Whiteside, J.H., Olsen, P.E., Kent, D.V., Fowell, S.J., Et-Touhami, M., 2007. Synchrony between the Central Atlantic magmatic province and the Triassic-Jurassic massextinction event? Palaeogeogr. Palaeoclimatol. Palaeoecol. 244, 345-367.

Whiteside, J.H., Olsen, P.E., Kent, D.V., Fowell, S.J., Et-Touhami, M., 2008. Synchrony between the Central Atlantic magmatic province and the Triassic-Jurassic massextinction event? Reply to Marzoli et al. Palaeogeogr. Palaeoclimatol. Palaeoecol. 262, 194-198.
Whiteside, J.H., Olsen, P.E., Eglinton, T., Brookfield, M.E., Sambrotto, R.N., 2010. Compound-specific carbon isotopes from Earth's largest flood basalt eruptions directly linked to the end-Triassic mass extinction. Proc. Natl. Acad. Sci. 107, 6721-6725.

Whiteside, J.H., Grogan, D.S., Olsen, P.E., Kent, D.V., 2011a. Climatically driven biogeographic provinces of Late Triassic tropical Pangea. Proc. Natl. Acad. Sci. 108, 8972-8977.

Whiteside, J.H., Olsen, P.E., Eglinton, T.I., Cornet, B., McDonald, N.G., Huber, P., 2011b. Pangean great lake paleoecology on the cusp of the end-Triassic extinction. Palaeogeogr. Palaeoclimatol. Palaeoecol. 301 (1), 1-17.

Witte, W.K., Kent, D.V., 1989. A middle Carnian to early Norian ( $225 \mathrm{Ma})$ paleopole from sediments of the Newark Basin, Pennsylvania. Geol. Soc. Am. Bull. 101, 1118-1126.

Witte, W.K., Kent, D.V., 1990. The paleomagnetism of red beds and basalts of the Hettangian Extrusive Zone, Newark Basin, New Jersey. J. Geophys. Res. 95 (B11), $17,533-17,545$.

Witte, W.K., Kent, D.V., Olsen, P.E. 1991. Magnetostratigraphy and paleomagnetic poles from Late Triassic-earliest Jurassic strata of the Newark Basin. Geol. Soc. Am. Bull. 103, 1648-1662.

Wotzlaw Jr., F., Guex, J., Bartolini, A., Gallet, Y., Krystyn, L., McRoberts, C.A., Taylor, D. Schoene, B., Schaltegger, U., 2014. Towards accurate numerical calibration of the Late Triassic: High-precision U-Pb geochronology constraints on the duration of the Rhaetian. Geology http://dx.doi.org/10.1130/G35612.1.

Zeigler, K.E., Geissman, J.W., 2011. Magnetostratigraphy of the Upper Triassic Chinle Group of New Mexico: implications for regional and global correlations among Upper Triassic sequences. Geosphere 7, 802-829.

Zeigler, K.E., Kelley, S., Geissman, J.W., 2008. Revisions to stratigraphic nomenclature of the Upper Triassic Chinle Group in New Mexico: new insights from geologic mapping, sedimentology, and magnetostratigraphic/paleomagnetic data. Rocky Mt Geol. 43, 121-141.

Zhang, Y., Li, M., Ogg, J.G., Montgomery, P., Huang, C., Chen, Z.-Q., Shi, Z., Enos, P., Lehrmann, D.J., 2015. Cycle-calibrated Magnetostratigraphy of middle Carnian from South China: implications for Late Triassic Time Scale and Termination of the Yangtze Platform. Palaeogeogr. Palaeoclimatol. Palaeoecol. 436, 135-166. 